\title{
Market orientation and business performance: An empirical study comparing Canadian manufacturers and telecommunications equipment manufacturers of Canada
}

by

\section{Alain Rojas-Saldana}

A thesis submitted to

The Faculty of Graduate Studies and Research

In partial fulfillment of the requirements for the degree of

Master of Business Administration

Eric Sprott School of Business

Carleton University

Ottawa, Ontario

Alain Rojas Saldana, 2004. 


$\begin{array}{ll}\begin{array}{l}\text { Library and } \\ \text { Archives Canada }\end{array} & \begin{array}{l}\text { Bibliothèque et } \\ \text { Archives Canada }\end{array} \\ \begin{array}{l}\text { Published Heritage } \\ \text { Branch }\end{array} & \begin{array}{l}\text { Direction du } \\ \text { Patrimoine de l'édition }\end{array} \\ \begin{array}{l}\text { 395 Wellington Street } \\ \text { Ottawa ON K1A 0N4 }\end{array} & \begin{array}{l}\text { 395, rue Wellington } \\ \text { Ottawa ON K1A ON4 } \\ \text { Canada }\end{array} \\ \end{array}$

Your file Votre référence ISBN: 0-612-99020-6

Ourfile Notre référence

ISBN: 0-612-99020-6

NOTICE:

The author has granted a nonexclusive license allowing Library and Archives Canada to reproduce, publish, archive, preserve, conserve, communicate to the public by telecommunication or on the Internet, loan, distribute and sell theses worldwide, for commercial or noncommercial purposes, in microform, paper, electronic and/or any other formats.

The author retains copyright ownership and moral rights in this thesis. Neither the thesis nor substantial extracts from it may be printed or otherwise reproduced without the author's permission.
AVIS:

L'auteur a accordé une licence non exclusive permettant à la Bibliothèque et Archives Canada de reproduire, publier, archiver, sauvegarder, conserver, transmettre au public par télécommunication ou par l'Internet, prêter, distribuer et vendre des thèses partout dans le monde, à des fins commerciales ou autres, sur support microforme, papier, électronique et/ou autres formats.

L'auteur conserve la propriété du droit d'auteur et des droits moraux qui protège cette thèse. $\mathrm{Ni}$ la thèse ni des extraits substantiels de celle-ci ne doivent être imprimés ou autrement reproduits sans son autorisation.
In compliance with the Canadian

Privacy Act some supporting forms may have been removed from this thesis.

While these forms may be included in the document page count, their removal does not represent any loss of content from the thesis.
Conformément à la loi canadienne sur la protection de la vie privée, quelques formulaires secondaires ont été enlevés de cette thèse.

Bien que ces formulaires aient inclus dans la pagination, il n'y aura aucun contenu manquant. 


\begin{abstract}
This research studied and measured the relationship between market orientation and performance, and the moderating influence of environmental factors independently on performance, and on the market orientation - business performance link. These associations were compared between Canadian businesses across a wide range of sectors to those in the telecommunications sector.

The results showed a clear association between market orientation and the four measures of performance used in this study. They also showed that competitive intensity negatively affects the performance of manufacturing industry companies, but not telecommunications industry companies. It also found that both competitive intensity and overall market demand moderate the link between market orientation and performance for manufacturing industry companies, but not for telecommunications industry companies. This suggests that the performance of telecommunications companies depends more on actions originated from within the company and are affected less by differences in external environmental variables than manufacturing industry companies.
\end{abstract}




\section{Table of Contents}

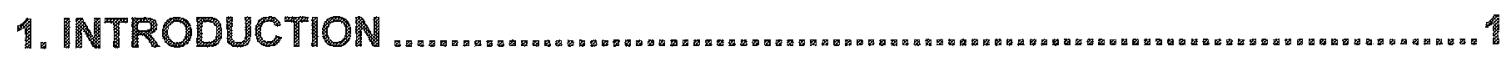

21 The stages of marketing management ........................................................................................ 4

2.1. Production orientation stage

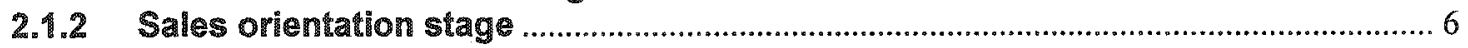

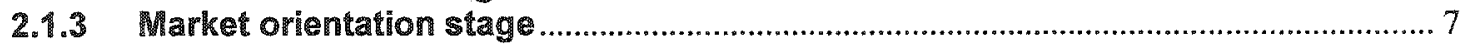

2.1.4 The optimal strategy ................................................................................................... 9

2.1.5 Fluctuations in conditions and changing orientations ........................................... 9

2.2 Defining Market Orientation ............................................................................................................. 11

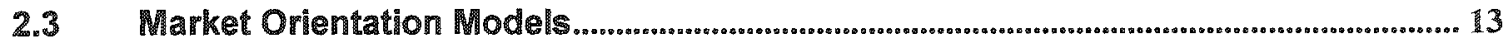

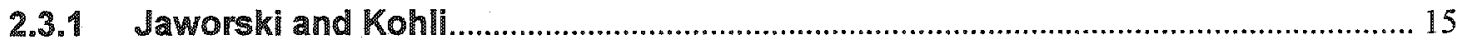

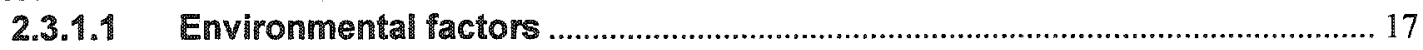

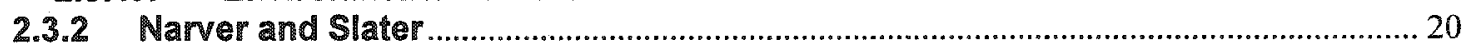

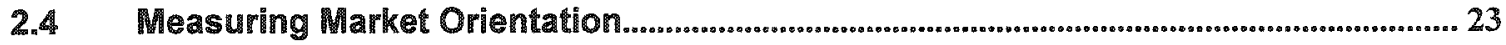

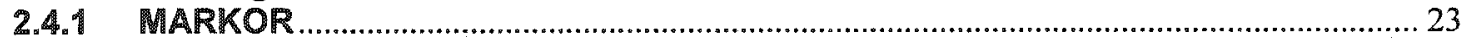

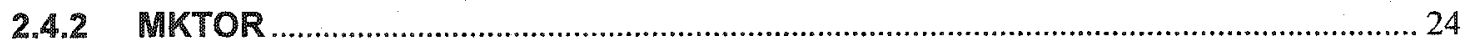

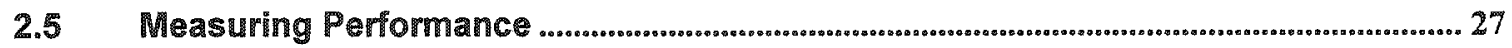

2.6 Market Orientation Studies ..................................................................................................... 30

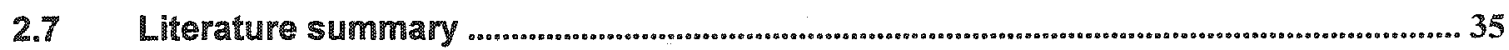

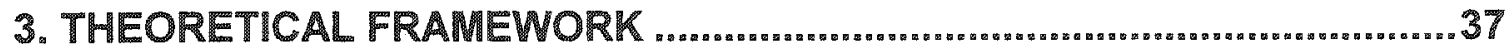

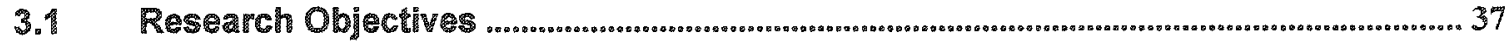

3.2 ReSERTh MOdUl

4. RESEARCH METHODOLOGY

4.1 ReSearch design

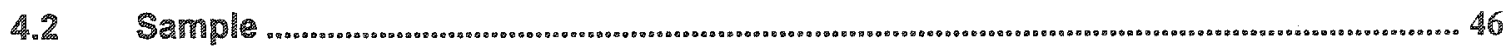

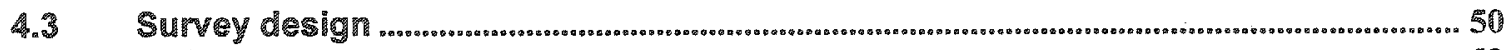

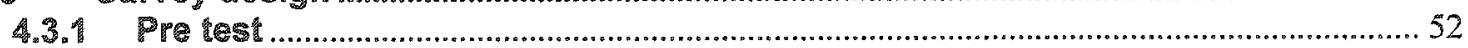

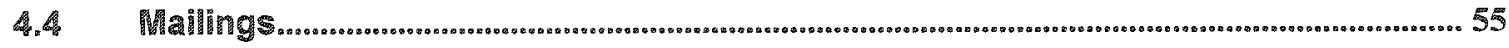




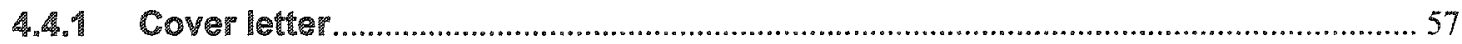

4.4.2 Returt post card ...................................................................................................... 57

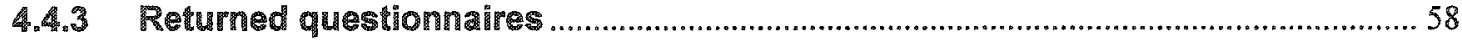

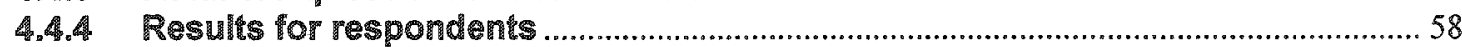

5. DATA ANALYSIS AND RESULTS ................................................60

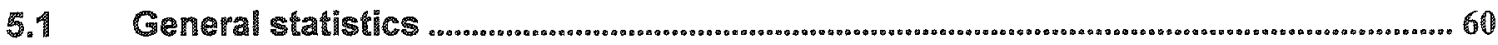

5.1.1 Response levels and representativeness of the sample........................................6 60

5.1.2 Measures of dependent and independent variables ...............................................67

5.2 Data preparation for hypothesis and model testing .................................................... 68

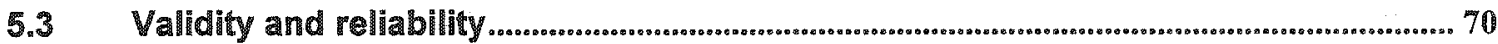

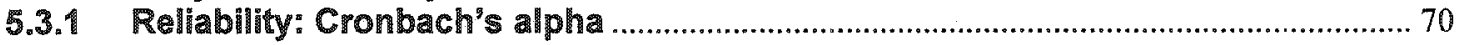

5.3.2 Validity: Convergent and Discriminant validity ....................................................... 72

5.4 Market orientation, the environment and performance .................................................. 78

5.4.1 Market orientation vs. Performance: model 1 ….................................................... 78

5.4.2 Performance vs. market orientation and environmental variables: model 2 2....... 79

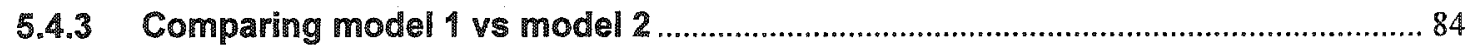

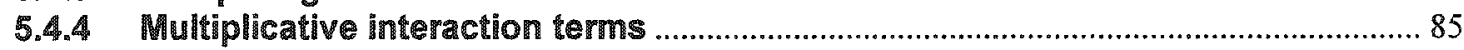

5.5 Comparing the telecommunications industry to other manufacturing industries... 93

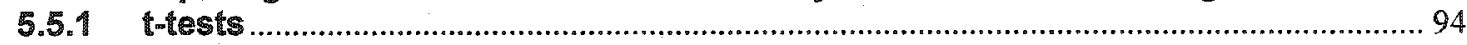

5.5.2 Comparing regressions of telecommunication and manufacturing groups......... 96

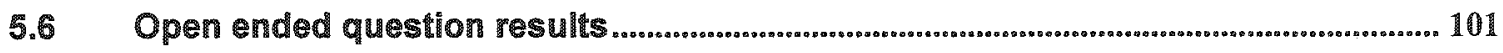

6. SUMMARY OF RESULTS AND DISCUSSION

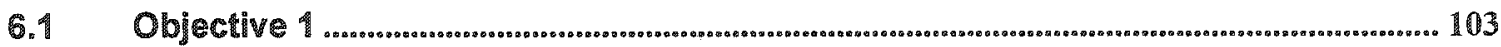

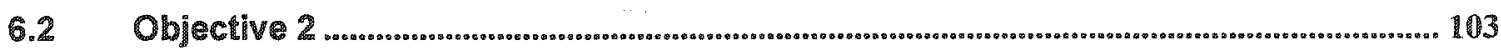

6.3 ObjeCtive 3 .....n.

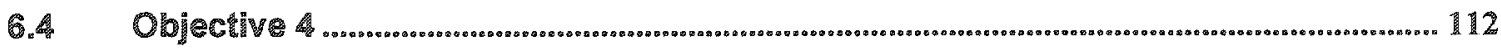

7. LWMITAT 1 NS

8. BENEFIIS AND MPPUICATIONS.

REFERE

APPENDICE 
Appendix A: Market Orientation scalle comparison.

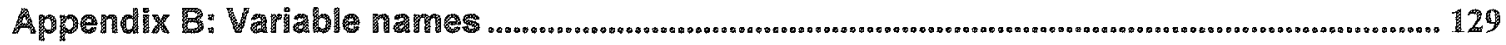

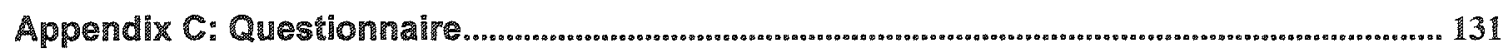

Appendix D: Cover letter, first round ........................................................................................... 136

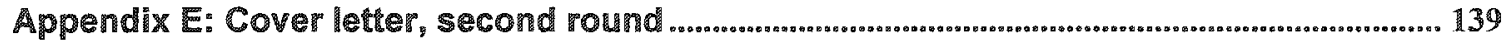

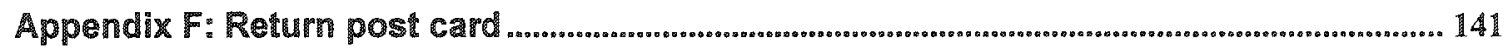

Appendix G: Cover letter, results to respondents .................................................................. 143

Appendix H: Results to respondents ............................................................................................... 145

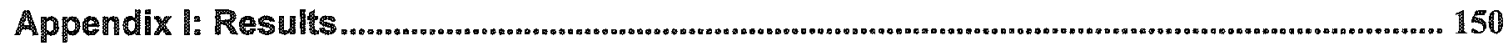

1.1 Histograms of mean variables ..................................................................................................... 151

I.2 Cronbach's alpha ............................................................................................................................ 154

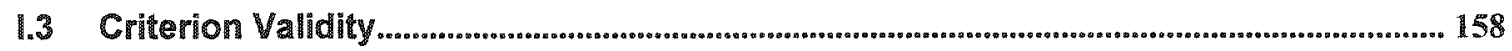

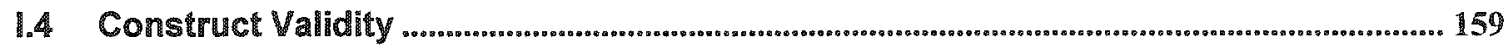

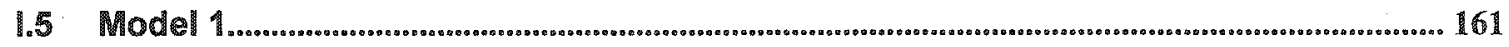

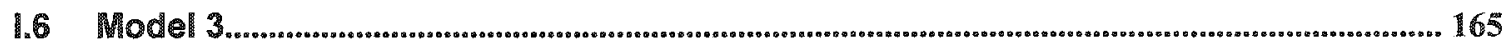

1.6.1 Market turbulence multiplicative interaction term ............................................... 165

1.6.2 Competitive intensity multiplicative interaction term ........................................... 169

1.6.3 Technological turbulence multiplicative interaction term ................................... 173

1.6.4 Demand multiplicative interaction term.................................................................. 177

1.7 Manufacturing vS. telecommunication: $t$ tests .............................................................. 181

1.8 Manufacturing vs. telecommunications: regressions ...................................................... 182 


\section{Tables}

Table 1. Key characteristics of the production orientation stage .........................6

Table 2. Key characteristics of the sales orientation stage ..............................

Table 3. Key characteristics of the market orientation stage ............................... 8

Table 4. Characteristics of a market orientation as used in this research ..........13

Table 5. Studies on the link between market orientation and performance.........33

Table 6. List of variables ..............................................................................40

Table 7. Telecommunication group vs. manufacturing group responses ...........60

Table 8. Personal question responses statistics ............................................61

Table 9. First vs. Second round responses..................................................65

Table 10. $t$ tests to compare 1st and 2nd round respondents ........................66

Table 11. t-test between respondents and non-respondents ........................66

Table 12. Means of dependent and independent variables .............................68

Table 13. List of single item overall impressions for each variable ....................69

Table 14. Cronbach's alpha results for each scale .......................................71

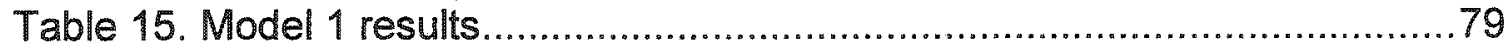

Table 16. Model 2 for Performance relative to company objectives ...................81

Table 17. Model 2 for performance relative to competitors ............................82

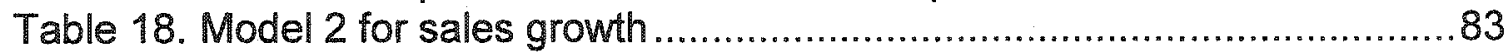

Table 19. Model 2 for market share growth ................................................. 84

Table 20. Competitive intensity multiplicative interaction term against performance relative to company objectives..................................8 87

Table 21. Demand interaction term vs. performance against the competition ...99

Table 22. Demand against market share growth .........................................92

Table 23. Significant t-tests between manufacturing and telecommunication

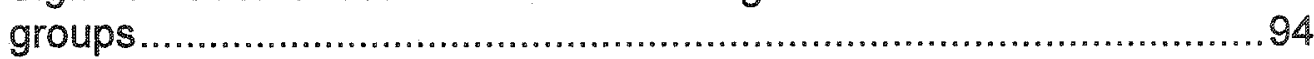

Table 24. Per item t-test between telecommunications and manufacturing companies for the demand variable ................................................95

Table 25. Model 1, manufacturing vs telecommunication ...............................97

Table 26. Model 2, manufacturing vs. telecommunication ...............................98

Table 27. Model 3, Regression with demand multiplicative term for manufacturing companies only

Table 28. Model 3, Regression with competitive intensity multiplicative term for manufacturing companies only .................................................. 100

Table 29. Adjusted $R$ square comparisons of all regressions ........................ 109

Table 30. Market orientation scales compared to each other .........................126

Table 31. Regression of momean vs. perfmean ..........................................158

Table 32. Correlations between momean and a set of descriptions of business philosophies. 
Table 33. Correlations between market (environmental) variables 160

Table 34. Regression of MOMEAN vs. Performance relative to company objectives.

Table 35. Regression of MOMEAN vs. Performance against competitors........162

Table 36. Regression of MOMEAN vs. sales growth performance. 163

Table 37. Regression of MOMEAN vs. market share growth performance.......164

Table 38. Regression using market turbulence multiplicative interaction term vs. performance relative to company objectives.... 165

Table 39. Regression using market turbulence multiplicative interaction term vs. performance against competitors. 166

Table 40. Regression using market turbulence multiplicative interaction term vs. sales growth performance.

Table 41. Regression using market turbulence multiplicative interaction term vs. market share growth

Table 42. Regression using competitive intensity multiplicative interaction term vs. performance relative to company objectives.... 169

Table 43. Regression using competitive intensity multiplicative interaction term vs. performance against competitors

Table 44. Regression using competitive intensity multiplicative interaction term vs. sales growth performance

Table 45. Regression using competitive intensity multiplicative interaction term vs. market share growth.

Table 46. Regression using technological turbulence multiplicative interaction term vs. performance relative to company objectives

Table 47. Regression using technological turbulence multiplicative interaction term vs. performance against the competition

Table 48. Regression using technological turbulence multiplicative interaction term vs. sales growth performance

Table 49. Regression using technological turbulence multiplicative interaction term vs. market share growth

Table 50. Regression using demand multiplicative interaction term vs. performance relative to company objectives.

Table 51. Regression using demand multiplicative interaction term vs. performance against the competition

Table 52. Regression using demand multiplicative interaction term vs. sales growth performance

Table 53. Regression using demand multiplicative interaction term vs. market share growth

Table 54. $t$ tests between manufacturing and telecommunication, with respect to other variables....

Table 55. Regression of model 1, telecommunications companies only ..........182

Table 56. Regression of model 1 , manufacturing companies only.... 183 
Table 57. Regression of model 2, telecommunications companies only ...........184

Table 58. Regression of model 2, manufacturing companies only.

Table 59. Model 3, Regression with market turbulence multiplicative term for telecommunications companies only

Table 60. Model 3, Regression with market turbulence multiplicatiuve term for manufacturing companies only

Table 61. Model 3, Regression with competitive intensity multiplicative term for telecommunications companies only

Table 62. Model 3, Regression with competitive intensity multiplicative term for manufacturing companies only

Table 63. Model 3, Regression with technological turbulence multiplicative term for telecommunications companies only

Table 64. Model 3, Regression with technological turbulence multiplicative term for manufacturing companies only

Table 65. Regression with demand multiplicative term for telecommunications companies only....

Table 66. Model 3, Regression with demand multiplicative term for manufacturing companies only. 193 


\section{Illustrations}

Figure 1. Market Orientation - performance link models ...................................15

Figure 2. Jaworski and Kohli's [1993] model of Market Orientation ...................16

Figure 3. Models to be used for this research ....................................................39

Figure 4. Number of employees of respondent companies vs. Canadian population of businesses ...............................................................63

Figure 5. Annual sales of respondent companies vs. Canadian population of

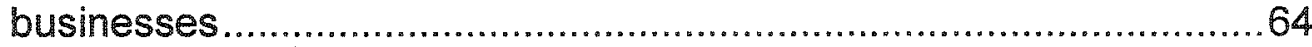

Figure 6. Market orientation, momean, histogram........................................... 151

Figure 7. Market turbulence, mkmtmean, histogram..................................... 151

Figure 8. Competitive intensity, mkcpmean, histrogram ..............................152

Figure 9. Technological turbulence, mkttmean, histogram...........................152

Figure 10. Demand, mkdmmean, histogram ................................................153

Figure 11. Performance, perfmean, histogram ............................................153 


\section{Appendices}

Appendix A: Market Orientation scale comparison ........................................125

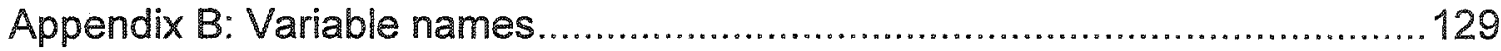

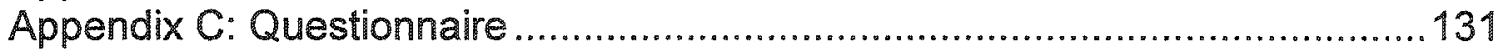

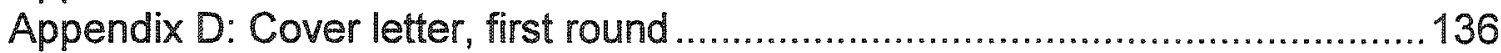

Appendix E: Cover letter, second round ....................................................139

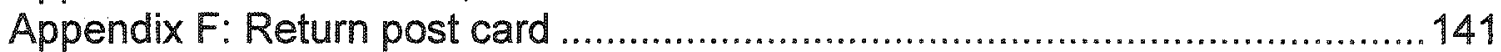

Appendix G: Cover letter, results to respondents......................................143

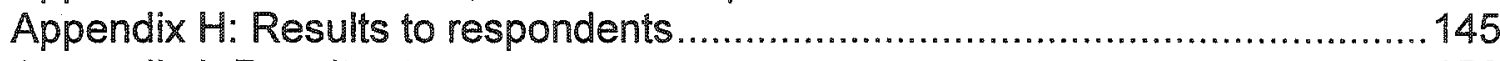

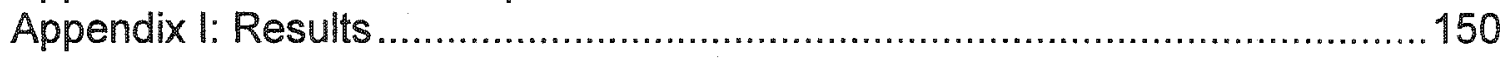




\section{INTRODUCTION}

A study of the history of marketing reveals that many industries evolve through a sequence of three general marketing management orientations [Sommers and Barnes, 2001], with associated demand/supply imbalances:

1. A production orientation, featuring a product-centric business focus, within markets experiencing excess demand.

2. A sales orientation, featuring heavy emphasis on sales and promotion activities, within markets experiencing excess supply.

3. A market orientation, featuring a customer-centric focus, within markets experiencing a balance between supply and demand.

In the last decade there have been successful efforts by several authors [Narver and Slater 1990, 1994; Jaworski and Kohli 1990, 1993; Jaworski et al 1993; Diamantopolos and Hart 1993; Deng and Dart 1994; Greenley 1995; Kwaku and Ashok 1998; Matsuno and Mentzer 2000; Harris 2001; Noble et al 2002] to find empirical evidence of a positive link between the degree of market orientation of a company and business performance.

The pattern of demand fluctuations observed in the marketing management orientation sequence has recently been observed in the telecommunications industry. At the end of the $20^{\text {th }}$ century there was an unprecedented increase in telecommunications equipment demand, followed by an unexpected slump in demand at the beginning of the new millennium. 
However, not all companies in the telecommunications industry have experienced the same decline in demand. It very well may be that those companies that have matured through the business orientation sequence and have shifted their orientation from a production orientation to a market orientation are more likely to have experienced successful business performance.

Each phase in the business orientation sequence has been found to be characterized by a particular condition of surrounding environmental factors. The most commonly cited environmental factors are overall market demand, technological turbulence, competitive intensity and market turbulence. The condition of these environmental factors may moderate the strength of the relationship between market orientation and business performance. Understanding the moderating effect of the environmental variables on the market orientation - performance link is critical in assessing whether certain industries with particular supply and demand balances may or may not be significantly assisted by a market orientation.

In recent years, the telecommunications industry may be suffering from a particular combination of these environmental factors, such as high technological turbulence and low overall market demand. With a deeper understanding of the environmental influences on the link between market orientation and performance, it may be easier to analyze the current state of the telecommunications industry and to recommend the most effective business orientation strategies for their situation. 
This study will try to understand and measure the moderating influence of environmental factors on the market orientation - business performance link, while at the same time obtaining further empirical evidence supporting such a link. Additionally, given the recent changes in the environmental factors experienced by the telecommunications industry, it will be the focus of this research to find the current degree of market orientation of firms in the telecommunications industry and recommend a preferred orientation strategy to ensure satisfactory business performance. 


\section{LITERATURE REVIEW}

The following sections present a review of the literature that provides the theoretical background for this research. Section 2.1 discusses the evolution of marketing through three stages, the production-orientation stage, the salesorientation stage and the market-orientation stage. Section 2.2 defines market orientation. Section 2.3 introduces the link between market orientation and business performance of a manufacturing company, and describes the most common market orientation - performance models that have been developed. Section 2.4 and 2.5 introduce the two most commonly used measurement scales for measuring market orientation, performance and other moderating variables. Section 2.6 describes in more detail the market orientation studies reviewed in this research. Finally, section 2.7 provides a summary of the literature review.

Throughout these sections, the telecommunications industry and the hypothesized role that market orientation plays in the telecommunications space as it stands today (2003) are introduced.

\subsection{The stages of marketing management}

Marketing as practiced in companies has evolved through three major stages in the last century: the production orientation stage, the sales orientation stage and the market orientation stage [Sommers and Barnes, 2001]. 


\subsubsection{Production orientation stage}

The production orientation stage had its peak in the first third of the twentieth century and was characterized by production and engineering executives running the company, the sales department role limited to selling the company's products, a minor role played by marketing activities [Sommers and Barnes, 2001], and the assumption that a good product will naturally sell [Byron, 1991]. High overall market demand was experienced throughout that period. This high overall market demand was in great part a result of new innovative products awakening a latent consumer demand that quickly translated into expressed demand [Berthon and Holbrook, 2000]. These characteristics are summarized in Table 1.

In most mature markets in developed economies, such conditions no longer exist. However, the telecommunications industry in the late $20^{\text {th }}$ century appears to have experienced these characteristics. In the closing decade of the last millennium, telecommunications manufacturers experienced an unprecedented demand for telecommunications equipment as a result of the internet boom prophesized by Worldcom's Vice Chairman John Sidgmore's claim that the Internet would double every 3 months [Zevcik, 1999]. Most innovations had little or no competition and were highly demanded [Lenain 2003], thus they sold themselves with little help from any marketing functions. Consequently, a 
production orientation approach was believed to be warranted, and companies were engineer driven [Workman, 1993].

Table 1. Key characteristics of the production orientation stage

Key characteristics of the production orientation stage:

- Excess demand

- Marketing functions play a minor role in the company

- Production and Engineering executives run the company

- The sales department sole role is to sell the company's products

- New products with no established markets, but for which there is a latent demand that is quickly translated into expressed demand

- Assumption that a good product will naturally sell

\subsubsection{Sales orientation stage}

During the early 1930's, supply exceeded demand in certain industries [Sommers and Barnes, 2001, Berthon and Holbrook, 2000] and thus a new marketing focus was required to maintain the sales levels most companies were now accustomed to. The sales orientation stage was thus characterized by extreme sales tactics, such as the "hard sell" approach [Sommers and Barnes, 
2001 ], increased advertising budgets, and a major focus on product promotion [Berthon and Holbrook, 2000].

\section{Table 2. Key characteristics of the sales orientation stage}

\section{Key characteristics of the sales orientation stage:}

- Excess supply

- Marketing functions play a promotional role in the company

- The sales department has a key role in the company

With the sudden swing in the balance between supply and demand, there was a shift of power from the seller to the buyer [Berthon and Holbrook, 2000]. This shift has just recently occurred in the telecommunications industry, where the high demand created by the "internet bubble" was followed by excess supply when the bubble burst at the beginning of the new millennium.

\subsubsection{Market orientation stage}

After the mid-1950's, marketing evolved into the new market-orientation stage that focused primarily on satisfying the customer. This stage is characterized by marketing executives participating actively in major business functions within the company (such as product planning), a major emphasis on 
all marketing activities, and customer needs and wants seriously considered when designing the company's products [Sommers and Barnes, 2001 ].

As customers become more knowledgeable, demanding, and divergent in their preferences, the focus of this stage becomes more critical for the business success of the company.

Table 3. Key characteristics of the market orientation stage

Key characteristics of the market orientation stage:

- Focus on the customer

- Marketing functions play a key role in the company

- The marketing department plays a key role in the company

- Product design is driven by customer needs and wants

This stage is characterized by the stabilization between demand and supply, given that only those companies that were truly competitive through a market orientation could maintain business performance and thus survive the demand slump of the previous stage. It is thus expected that those telecommunications companies that have a market orientation will maintain business performance and thus survive the current slump in demand for telecommunications equipment. 


\subsubsection{The optimal strategy}

Although there are more than eight empirical studies providing evidence to the positive link between market orientation and business performance, this does not imply that a market orientation is the solution to every woe or that it is the optimal strategy for all companies, industries or eras [Noble et al, 2002, Byron 1991]. For instance, the studies from Harris [2001] and Noble et al [2002] did not find an obvious link between market orientation and business performance. There are several environmental factors, besides excess demand, that may allow a company to be successful without the help of a market orientation. In those situations it may be equally or more useful for a company to focus on a production orientation or a sales orientation [Sharp, 1991, Brownlie, 1987]. These environmental factors are discussed in section 2.3.1.1.

\subsubsection{Fluctuations in conditions and changing orientations}

The marketing management orientation sequence is not unique to the eras mentioned above. Sub cycles seem to reappear in other periods, affecting specific industries, due to various economic and social factors. After the Second World War, for example, there was another surge in excess demand that, in turn, found many manufacturers reverting to the production stage mechanics and soon after into the sales production stage tactics [Sommers and Barnes, 2001]. 
If the telecommunications industry is currently experiencing a shift in demand, companies in the industry may benefit from modifying their current orientation from a production orientation to a sales or market orientation to improve business performance.

It is important to note that the shift in the environment experienced by a specific industry is not immediate or easily recognizable. Thus, there may be a time lapse between the moment the company becomes conscious of this shift and the moment it actually begins to adapt to these new environmental factors. This is further hampered by internal resistance to changes in organizational orientations, such as a change from a production orientation to a market orientation [Jaworski and Kohli 1990], which is sure to include internal power struggles and changes in organizational mentalities. Thus it may be important to measure both a market orientation attitude and actual actions reflecting a fully deployed market orientation, given that intentions may or may not lead to actions.

Another lag may be found between the time a company embraces a market orientation and the time such an orientation results in improved organizational performance [Harris 2001]. This lag may negatively affect the legitimacy of results obtained when measuring the link between market orientation and performance, especially in an industry currently experiencing environmental changes and orientation shifts such as may be the case for the telecommunications industry. 


\subsection{Defining Market Orientation}

According to Byron [1991], a market orientation typically ignores company objectives and competencies in favor of customer wants and needs. He suggests that, if a market orientation is to be successful, it must be based on the company's objectives and competencies.

Furthermore, the market orientation concept entails understanding the market, the environmental factors affecting it, customers and competitors [Narver and Slater 1994, Jaworski and Kohli 1993], and therefore does not automatically mean that products must be designed simply to satisfy expressed general market wants and needs [Houston, 1986]. For instance, the case may be that once a market is understood a company may build its products ignoring a particular market segment's wants and needs. For example, telecommunication equipment manufacturers usually try to avoid costly support of outdated communications protocols in their newer units given that these cater to legacy networks that represent a shrinking market. Also, in markets with high market and technological turbulence, current users may be ineffective predictors of future needs, which may be better anticipated by lead users or even product designers.

It is also important to distinguish between marketing activities and the marketing department [Workman, 1993]. In the telecommunications industry, the department in charge only of the promotion of the company's products is often referred to as the marketing department [Morgan and Morgan, 1991]. In addition, 
although product managers carry out several marketing activities such as pricing, channel management, and product planning, often they do not admit to being marketers [Morgan and Morgan, 1991] and most do not have formal marketing training. Marketers in this type of high-tech industry are regarded as not having the necessary knowledge and frame of reference to make key product related decisions, as well as having "functional fixedness with regard to technical attributes of the company's products" [Workman 1993]. Moreover, Workman [1993] concludes that in high tech companies, if pricing, channel management, or product planning is done by the marketing department, then it is considered useless by the rest of the company. This is due to perceptions of marketing responsibilities and capabilities within high tech companies.

Thus, given this decentralization of marketing activities across all departments, organization-wide market orientation can be described as an organizational philosophy articulated in actions performed across all departments, and not just a list of necessary activities that are carried out by a marketing department. (Note that in Table 3, there is a distinction between the increased role of marketing activities in a company and the increased role of the marketing department).

This research is interested in observing whether certain industries in Canada, such as the telecommunications industry, are at the market orientation stage. Therefore from a review of definitions used by various researchers, the following definition of the term market orientation has been developed and will be 
the operating definition for the remainder of this document. Market Orientation will refer to an organizational philosophy focused on the customer, revealed through marketing functions performed across the entire company and a product design process driven by an understanding of the market, its competitors, and its customers' needs and wants, in line with the corporation's strategy and competencies. A summary of these characteristics is shown in Table 4 (and is a slightly expanded but focused version of Table 3 ).

Table 4. Characteristics of a market orientation as used in this research

\section{Characteristics of a market orientation as used in this research}

- Focus on the customer

- Marketing functions play a key role throughout the entire company

- Product design is driven by an understanding of the market, its competitors, and its customers' needs and wants in line with the corporation's strategy and competencies

\subsection{Market Orientation Models}

In the last few decades market orientation has become a popular theme to research. Dozens of studies have proposed several theories on what market orientation entails, what are its basic components, how it relates to the 
company's business performance, and what the various factors are that affect this relationship. Of all these studies the works of two groups of authors predominate; a series of studies by Jaworski and Kohli, and another series by Narver and Slater.

Most studies focused specifically on market orientation as an independent variable, environmental variables (where included) as moderator variables, and business performance as the dependent variable (Figure 1a). Those studies proposed that the greater the market orientation of a company, the better its business performance [Jaworski and Kohli, 1993]. Some studies also proposed that this association was affected by external environmental factors [Jaworski and Kohli, 1993].

However, another group of studies [Narver and Slater 1990, 1994; Greenley 1995; Harris 2001] suggest a direct link between business performance and both a company's market orientation and the environmental factors experienced by it (Figure 1b).

It is important to note that, of the ten studies reviewed in this research and discussed in section 2.6 , seven found a positive link between market orientation and business performance. They also proposed that the strength of this relationship is moderated by certain environmental factors. Section 2.6 discusses in more detail the results of those studies measuring the link between market orientation and performance. 
Figure 1. Market Orientation - performance link models

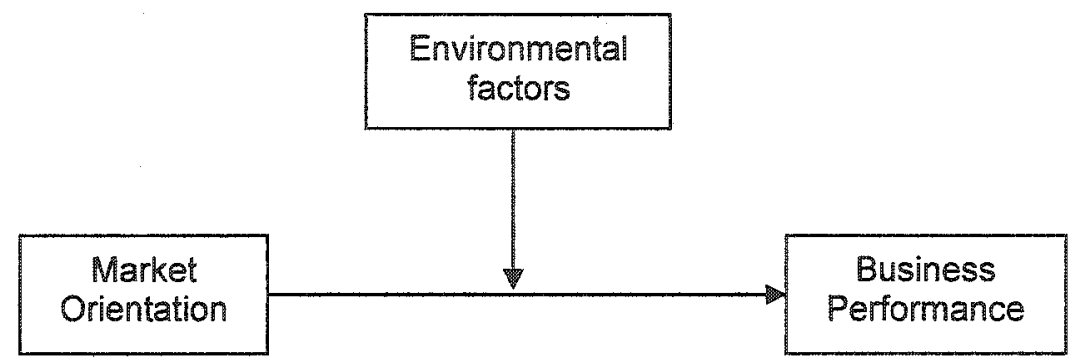

a)

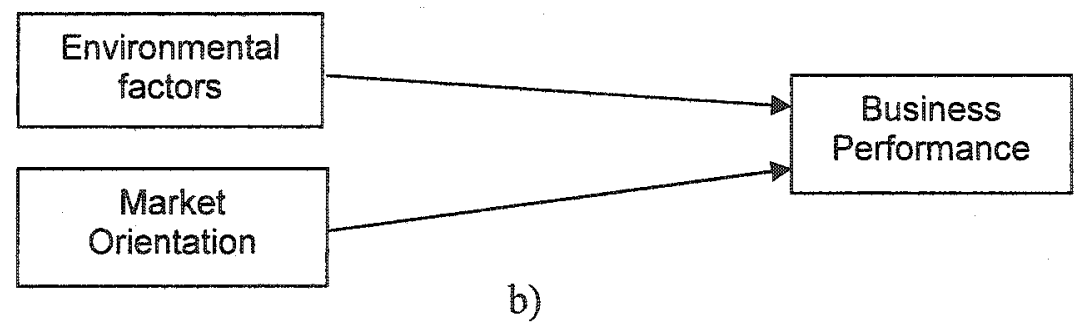

\subsubsection{Jaworski and Kohli}

Jaworski and Kohli's studies and customer orientation measurement scale were based on the model shown in Figure 2 [Jaworski and Kohli, 1993].

According to Jaworski and Kohli's model, a true market orientation that successfully translates the marketing concept into practice [Jaworski and Kohli, 1990], has three components:

1. Intelligence generation: The "collection and assessment of both customer needs/preferences and the forces that influence the 
development and refinement of those needs" [Jaworski et al, 1993]. The authors note that these activities engage several departments within the company.

2. Intelligence dissemination: The degree of communication between departments (regardless of whether they are marketing related or not) and between managers and their subordinates in the same department, concerning the intelligence described in the previous point.

3. Responsiveness: The actions taken as a response to the intelligence described in the previous points.

Figure 2. Jaworski and Kohli's [1993] model of Market Orientation

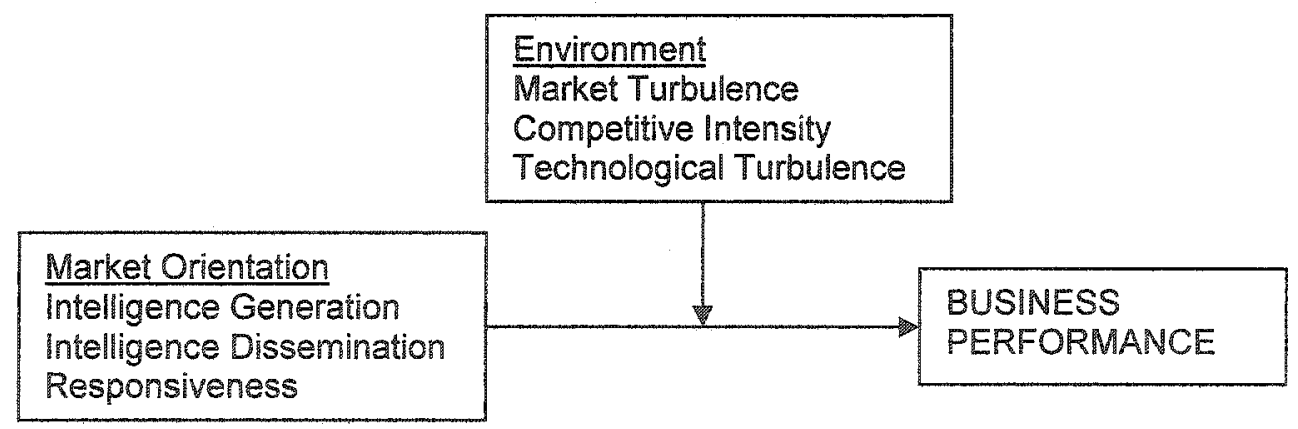

The authors note that these three variables affect primarily the design and development of the company's products. Therefore, the key stakeholders are 
those that play a direct role in these activities. In the telecommunications industry, for example, those in charge of the design and development of the company's products are the product managers, usually under the mandate of the research and development department. On the other hand, the marketing department in that industry typically has limited influence in those activities.

Identifying all stakeholders within a company is in line with the idea that market orientation is a company-wide business philosophy [Gauzente 1999, Deng and Dart 1994]. It also matches the idea of market orientation being a philosophy driven by an understanding of the market, its competitors, and its customers' needs and wants in line with the corporation's strategy and competencies. All of these characteristics are described in Table 4 and are the basis for this research.

\subsubsection{Environmental factors}

The model shown in Figure 2 indicates three environmental variables that moderate the link between market orientation and a company's business performance.

- Market Turbulence

- Competitive Intensity

- Technological Turbulence 
Market turbulence refers to how quickly the customer's needs and wants change in a specific industry. According to Jaworski and Kohli [1990], the greater the market turbulence, the stronger the relationship between market orientation and the company's performance will be. This means that the greater the market orientation of a company the more effectively it will react to the customer's needs shifts. However, Byron [1991] argues that if market preferences are unstable enough, then market orientation may prove impractical given that the speed of changes in customer requirements makes market research impossible.

The competitive intensity variable argues that the greater the amount and more aggressive the competition, the greater the requirement for market intelligence. This is necessary to effectively react to a competitor's campaigns targeted at the company's customers.

The telecommunications industry, for example, enjoyed several decades of limited competition due to a high demand and the possibility of opening entirely new markets by developing new products and technologies [Lenain 2003]. Unfortunately, now that demand has plummeted, telecommunication manufacturers face the prospect of having to fight against hundreds of competitors offering just as innovative products, for the few remaining sales opportunities [Lenain 2003, Steinke 2003].

Lenain [2003] and Steinke [2003] argue that in technologically intensive industries, most new products evolve from R\&D innovations and not from customer needs. Therefore in those types of industries, the link between a 
market orientation and organizational performance may not be as important as in other industries. However, it should be noted in rebuttal that a market orientation does not mean simply and directly responding to customers expressed needs. Rather it involves sensitivity to all market driving forces and the anticipation of evolving and future market needs.

The telecommunications industry has experienced constant technical turbulence (technological intensity) for the last few decades. It has faced intense time to market pressures and changes in other technologically related factors, such as deregulation and changing standards, which may also thwart the ability to carry out timely marketing activities within the company [Workman 1993]. On the other hand, due to the increase in demand experienced at the end of the $20^{\text {th }}$ century several new competing companies and technologies were born [Lenain 2003]. Unfortunately, given the current telecommunication woes, both new and old companies now face a sudden decrease in demand and increase in competition intensity [Lenain 2003, Steinke 2003]. Therefore, a more thorough analysis of the market, including both customers and competitors, may be required now for a company to maintain its competitiveness.

In addition to the three environmental factors proposed by Jaworski and Kolhi [1990], the authors mention that "in a strong economy characterized by strong demand, a company may be able to get away with a minimal amount of market orientation". However, this factor (demand) is not mentioned in their model or in other future studies using their model. Nonetheless, several authors 
[Carson, 1985, Narver and Slater, 1994, Houston 1986, Greenley 1995] support the idea that in high overall market demand conditions marketing activities may not be required to be profitable. In fact, the key environmental factor associated with the business orientation sequence is changes in relative demand.

The telecommunications industry experienced high demand at the end of the $20^{\text {th }}$ century and thus may not have required a market oriented focus to be highly profitable [Lenain 2003]. However, due to a telecommunications equipment glut and unrealized end user demand at the turn of the millennium, telecommunications equipment manufacturers face very limited demand from service providers, a high level of competition from hundreds of startups with thousands of innovations, and ever changing technological and market related elements [Lenain 2003, Steinke 2003]. If a link is found between environmental characteristics and the Market Orientation - Performance continuum, the three factors proposed by Jaworski and Kohli [1993] and market demand may well play a critical role in the preferred orientation strategies of telecommunication firms.

\subsubsection{Narver and Slater}

Narver and Slater [1994] proposed a model similar in structure to Kolhi and Jaworski's, but added a few other environmental variables into the equation. Their original model differs from Kolhi and Jaworski's in that their proposed 
market level factors affect business performance directly instead of through a moderating effect on the market orientation - performance link.

According to Narver and Slater, a market orientation is composed of five components [Narver and Slater, 1990].

1. Customer orientation: This component refers to the company's efforts to know their customers.

2. Competitor orientation: Competitor orientation refers to the company's efforts to know their competitors.

3. Inter functional coordination: This component refers to the degree in which all departments in the company coordinate their efforts and use marketing intelligence to create value to customers.

4. Long term focus

5. Profit objective

Diamantopoulus and Hart [1993] link Narver and Slater's [1990] first three components to Jaworski and Kohli's [1993] market orientation components. They relate Narver and Slater's [1990] customer orientation and competitor orientation components to Jaworski and Kohli's [1993] intelligence generation, and Narver and Slater's [1990] inter-functional coordination to Jaworski and Kohli's [1993] intelligence dissemination. They note, though, that there is no equivalent component in Narver and Slater's [1990] work to Jaworski and Kohli's [1993] responsiveness component. 
Another major downside to Narver and Slater's [1990] model is the idea of considering profitability and long term focus as part of market orientation. It can be argued that any other orientation strategy may also have profitability and long term focus as an essential component, thus it is not a component that clearly distinguishes a market orientation from other alternatives. Another view is that profitability is not a part of market orientation, but a consequence of it [Jaworski and Kohli 1990], i.e. a performance measure.

Finally, Gauzente [1999] argues that Narver and Slater's [1990] model focuses more on measuring the company's customer commitment. In contrast, Jaworski and Kohli's [1993] model studies the implementation of a market oriented philosophy [Gauzente, 1999, Deng and Dart, 1994, Gray and Matear, 1998].

Narver and Slater [1994] use Jaworski and Kohli's environmental factors in their study, although they argue that the environmental factors are transient and thus a long term market orientation will work despite short term environmental factors [Narver and Slater 1994]. This argument may not necessarily hold in industries where the environmental factors remain for long periods, such as technological turbulence in high-tech industries.

Additionally, the authors propose that some market level factors, such as buyer power, seller concentration, ease of entry, market growth, technological change, and supplier power, affect business performance directly [Narver and 
Slater, 1990], instead of through a moderating effect on the link between market orientation and performance.

\subsection{Measuring Market Orientation}

As well as market orientation models, several measurement scales have been developed in the last few decades to measure the market orientation construct. Once again, both Jaworski and Kohli, and Narver and Slater developed the most widely used measurement scales, MARKOR and MKTOR respectively.

Subsequently, other authors have modified these scales to fit their research, as well as having tried to improve on the measures themselves [Gray and Matear, 1998, Matsuno, 2000, and Deng and Dart 1994].

\subsubsection{MARKOR}

The MARKOR measurement scale [Jaworski et al, 1993] is widely used to study market orientation in the relevant literature. It is a viable instrument to measure the company's implementation of the market orientation philosophy and its ability to respond to environmental factors [Gauzente 1999]. However, Deng and Dart [1994] note that the scale's generic (philosophical) questions may be subject to "lip service" (i.e. insincere replies). 
There are two versions to the MARKOR scale, a 32-item scale and a 20item scale which is a subset of the 32 -item scale. The 20 -item scale was proposed by the authors to improve the fit of the scale, as well as to reduce the probability that a respondent will not respond due to the scale being too long and impractical [Jaworski et al, 1993]. These scales are referred to in this research as MARKOR32 and MARKOR20 respectively.

MARKOR32 contains ten items to measure the intelligence generation component in their market orientation model, eight for the dissemination component, and fourteen for their responsiveness component. MARKOR20 contains six items to measure the intelligence generation component in their market orientation model, five for the dissemination component, and nine for their responsiveness component.

Both scales have been tested empirically by their authors using a confirmatory factor analysis. Unfortunately, the fit statistics for each model are far from ideal [Matsuno, 2000, Farrell and Oczkowski, 1997].

\section{4 .2 MKTOR}

The MKTOR scale [Narver and Slater 1990] is also widely used to measure the market orientation construct, although as previous discussions indicate it lacks the necessary variables to measure the responsiveness component of the Jawroski and Kohli model [1993]. Additionally, Gauzente 
[1999] argues that MKTOR is more suited to evaluate a firm's commitment to its customers which may not be linked to a market orientation cultural philosophy [Gauzente, 1999].

Given that this research is interested in finding a company's implementation of the market orientation philosophy versus a customer orientation, it may prove more useful to use a scale based on Jaworski et al's [1993] MARKOR scale vs. Narver and Slater's [1990] MKTOR scale, as per Gauzente's [1999] recommendation.

\subsubsection{Other measurement scales}

Since the introduction of the MARKOR scale [Jaworski and Kohli 1993], several authors have modified this scale to improve the scale in different aspects. Farrell and Oczkowski, [1997] for example, improved the scale's goodness of fit by deleting items from the original MARKOR20, using standard correlation (EQS) residuals to determine which items to delete. They ended up with a 10 -item scale" that they feel "maintains a reasonable balance between the various sub constructs"2, while at the same time improving the goodness of fit of the model. They also argued that a shorter scale is much easier to administer than a larger scale. Additionally, Gauzente's [1999] study of the MARKOR scale concluded that the MARKOR scale is best suited to study the company's implementation of

\footnotetext{
${ }^{1}$ See appendix A

22 items for ID, 5 items for $1 G$ and 3 items for RESP
} 
the market orientation philosophy on question wording and vocabulary richness. Therefore Farrell and Oczkowski's [1997] reduced 10-item scale may also prove suitable for this purpose given that it maintains question wording and vocabulary.

Soon after, Gray and Matear [1998] combined both the MARKOR and the MKTOR scales into a single 20-item scale which they argued is more managerially useful and parsimonious. They used Cronbach's alpha scores and an exploratory factor analysis as the basis for selection. Their final scale contained only 4 questions derived from Jaworski et al's [1993] MARKOR scale and the rest from Narver and Slater's [1990] MKTOR scale.

To improve the goodness of fit of the MARKOR scale, Matsuno [2000] also redesigned the scale by retaining only seven items of the original MARKOR scale and adding 15 new ones. Fit statistics (modification index and standardized residuals) and reliability statistics (item-to-item, item-to-total correlation, and Cronbach's alpha) were used to decide which items to delete and which to retain. He argued the new MO scale improves operationalization of the constructs, while at the same time improving its psychometric properties. The resulting 22 -item "MO" scale differs significantly from the original MARKOR scale. Therefore, Gauzente's [1999] affirmations on MARKOR's viability to study the company's implementation of the market orientation philosophy and its ability to respond to environmental factors may not apply to the new MO scale [Matsuno, 2000].

Diamantopoulus and Hart [1993] built their own scale based on Jaworski and Kohli's [1990] intelligence generation, intelligence dissemination and 
responsiveness dimensions of market orientation, although they agree that their results are not directly comparable to other studies based on the MARKOR scale.

Deng and Dart [1994] are the only authors studied who proposed their own 25-item scale based on the MKTOR scale, designed to fit their study. They argued that their scale further distinguishes between a market orientation operationalization and a market orientation philosophy.

\subsection{Measuring Performance}

Throughout the related literature several performance variables are proposed to measure the market orientation - performance link, all of which can be divided into two groups: Objective and subjective measures of performance.

Objective measures of performance use sources of information external to the company and are in most cases quantitative. Subjective measures, on the other hand, are qualitative in nature and use the respondent's own points of view.

Most authors use only subjective measures of performance, arguing that [Matsuno 2000, Harris 2001, Kwaku and Ashok 1998, Narver and Slater 1990]:

i. Objective measures are almost impossible to get

ii. Subjective measures are used in all other studies

iii. Subjective measures are correlated to objective measures 
Of all the authors reviewed for this research only Harris [2001] and Jaworski and Kohli [1993] have paid close attention to objective measures of performance. Their results indicated no significant difference between the subjective and objective results, supporting the use of either form.

Whether subjective or objective, different authors use different measures of performance including performance relative to company objectives, performance relative to competition, sales growth, new product success, profitability, return on assets (ROA), market share growth and return on investment ( $\mathrm{ROI})$.

Of all the authors studied, the two measurement targets most used are performance relative to company objectives and sales growth. Performance relative to company objectives is useful in that it helps measure performance relative to the company's specific strategies and goals, whichever these may be. Sales growth measures, on the other hand, can be used not only to measure business performance, but also to find sales patterns for specific industries, such as the telecommunications industry in its current state. By comparing the expected poor sales performance of the telecommunications industry with other industries, patterns and other factors may be identified that affect the market orientation - performance link.

Another performance measure used by several authors [Matsuno and Mentzer 2000, Diamantopoulos and Hart 19931, pertormance relative to the competition, allows the company to compare itself agains the competition, thus 
measuring performance relative to specific organizational strategies without being influenced by poor sales experienced by entire industries. This permits companies to report good performance even when experiencing low sales resulting from external factors outside of the company's control. This quality is also shared by market share growth.

New product success is also used by four of the twelve authors. However, product success may be affected by low sales resulting from a poor economy or other external factors beyond the company's control.

In the case of profitability measurements, some authors consider profitability as a component of ROA, sales growth and new product success [Narver and Slater, 1990], thus indirectly measurable through these factors. Other authors [Diamantopoulus and Hart, 1993] caution on the use of profitability measures given that they may exclude positive performance of companies who focus on other company strategies. Some companies may sacrifice profitability in favor of other business goals, such as startup companies which usually seek market penetration instead of short term profitability. This can also be said for other measurement variables such as ROI and ROA.

In summary, the performance measures least influenced by changing company objectives and external economic factors are performance relative to company objectives, performance relative to competition and market share growth. On the other hand, the measure that may prove most useful to compare industries given current economic conditions is sales growth. 


\subsection{Market Orientation studies}

Table 5 summarizes the ten articles reviewed in this research which studied the link between market orientation and performance.

Narver and Slater's 1990 study was one of the first and most cited studies of the market orientation - performance link. It was based on 113 business units of a single forestry-based US corporation and was the first to introduce the MKTOR scale to measure the link with positive results. Specifically, they found a positive link between ROI (return on investment) and a market orientation.

Deng and Dart [1994] use the MKTOR scale on 248 Canadian firms varying in size, industry and geographic location within Canada. They found a positive link between market orientation and performance, although they did not study the moderating effect of environmental variables on the link.

Noble et al's 2002 study also used the MKTOR scale, but on the mass merchandiser retail industry, an industry characterized by high volume, low margin sales. They used shareholders as respondents and four firms in the industry over a period of ten years; JC Penny, Kmart, Sears and Wal-Mart. However, their results showed only weak mixed results when testing for a link between market orientation and performance. Specifically, they only found a significant link between the "competitor orientation" dimension of the market orientation construct (based on the definition by Narver and Slater [1990]) and 
both ROI and sales growth. They concluded that in that specific industry, focusing resources to meet competitor threats is the defining factor of the performance of the firm.

Diamantopoulus and Hart's 1993 study also focused on providing evidence of the Market Orientation - Performance link by using responses from 86 multi-industry UK manufacturing firms. They found only a weak relationship between the variables. Another UK study that found mixed results was a study by Harris [2001] on a sample of 241 firms in multiple industries whose names were obtained from the FAME database, a directory of UK and Irish companies. His study was focused on measuring performance objectively rather than subjectively, as is the case in most other studies. His study showed that objective measures were directly related to subjective measures of performance, but he found a link between market orientation and performance only when moderated by external environmental variables.

In contrast, two other UK studies showed positive results on the market orientation - performance link. Greenley [1995] found a positive market orientation - performance link when studying 240 UK multi-industry firms listed on the Dun and Bradstreet directory. Kwaku and Ashok [1998] studied 62 firms in the biotech industry of the UK. Their study also showed a positive link between market orientation and performance, although they didn't study environmental variables. However, they do note that their industry had high technological turbulence, high competitive intensity, and high market turbulence. 
Finally, Matsuno and Mentzer's [2000] study was based on 539 responses of US marketing executives obtained from a purchased mailing list. They found a positive link between market orientation and performance as well, although they also didn't study environmental variables.

In summary, seven of the ten studies reviewed showed a positive relationship between market orientation and performance, two found mixed results, and only one found a weak relationship. The performance measures most commonly used were sales growth [Narver and Slater 1990, Diamantopoulus and Hart 1993, Narver and Slater 1994, Deng and Dart 1994, Greenly 1995, Matsuno and Mentzer 2000, Harris 2001, Noble et al 2002] and performance relative to company objectives.

Jaworski and Kohli's 1993 study was the first to introduce the most widely used set of environmental variables, namely, market turbulence, competitive intensity, technological turbulence, and overall market demand. Their first sample was based on responses from 230 US firms listed in the Marketing Science Institute (MSI) directory and Dun and Bradstreet's Million Dollar Directory. It is important to note that this sample frame is limited to the top 1000 companies in sales revenue and thus excludes small and medium sized companies. Their second sample of 222 SBU's was derived from the American Marketing Association roster, which may exclude the opinions of product managers and CTO's in high tech companies. 
m

\begin{tabular}{|c|c|c|c|c|c|c|c|c|c|c|}
\hline 3 & $\S$ & $\begin{array}{l}\text { 帝 } \\
\frac{0}{2}\end{array}$ & 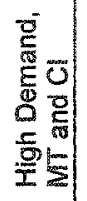 & $\begin{array}{l}\text { 总 } \\
\text { 일 }\end{array}$ & 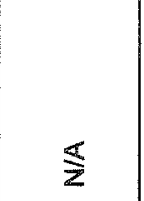 & $\begin{array}{l}\frac{E}{o} \\
\frac{\mathrm{g}}{\mathrm{m}} \\
\mathrm{s}\end{array}$ & 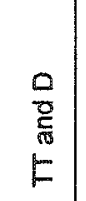 & $\S$ & 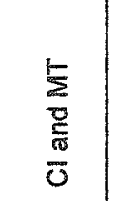 & $\S$ \\
\hline 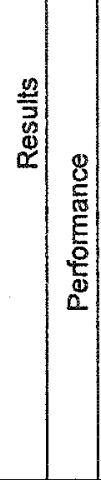 & 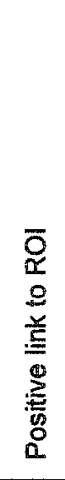 & 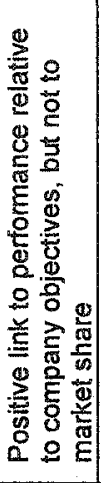 & 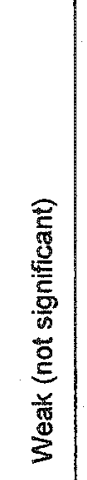 & 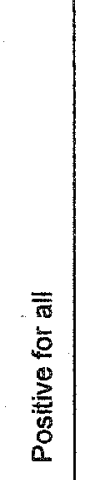 & 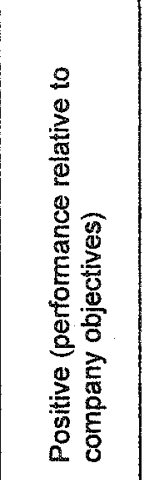 & 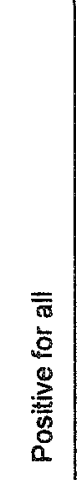 & 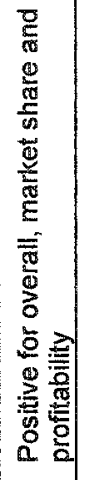 & 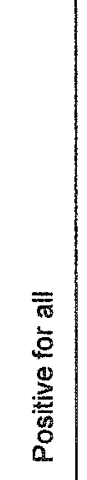 & \begin{tabular}{l} 
总 \\
文 \\
\multirow{2}{*}{}
\end{tabular} & $\begin{array}{l}\mathbf{D} \\
\stackrel{\tilde{X}}{\mathbf{z}}\end{array}$ \\
\hline 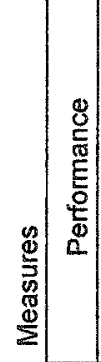 & $\bar{\alpha}$ & 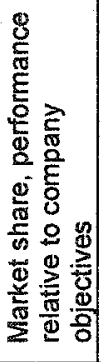 & 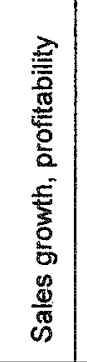 & 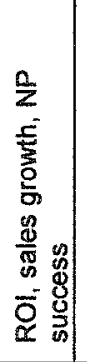 & 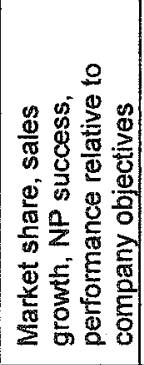 & 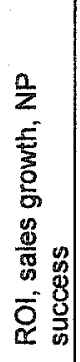 & 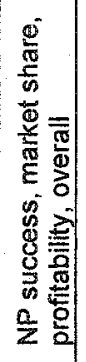 & 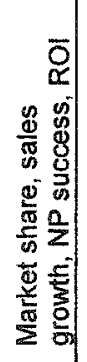 & 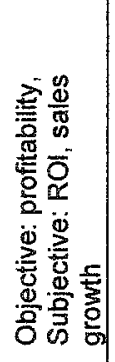 & 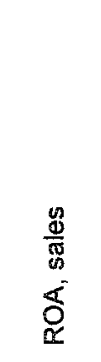 \\
\hline 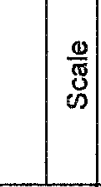 & $\begin{array}{l}\frac{\alpha}{0} \\
\frac{0}{2} \\
\end{array}$ & $\begin{array}{l}\text { ले } \\
\frac{0}{0} \\
\frac{1}{\alpha} \\
\frac{\alpha}{2} \\
\end{array}$ & 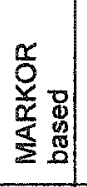 & $\frac{\frac{\alpha}{0}}{\frac{\alpha}{2}}$ & 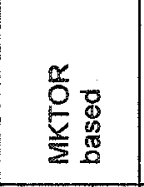 & $\begin{array}{l}\frac{x}{0} \\
\frac{\hat{g}}{\Sigma} \\
\frac{2}{2}\end{array}$ & $\begin{array}{l}\frac{\alpha}{0} \\
\frac{5}{\Sigma} \\
\frac{5}{\Sigma}\end{array}$ & 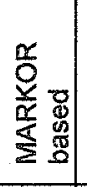 & $\frac{\sigma}{0}$ & $\frac{\frac{a}{0}}{\frac{5}{2}}$ \\
\hline 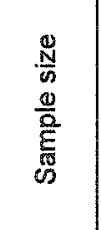 & 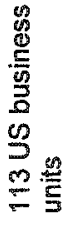 & 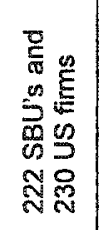 & 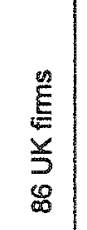 & 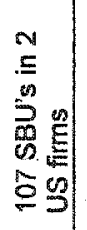 & 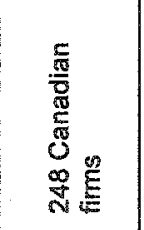 & 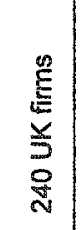 & 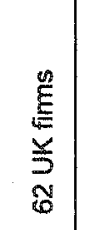 & 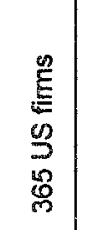 & 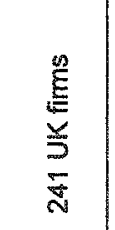 & 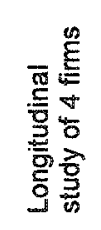 \\
\hline 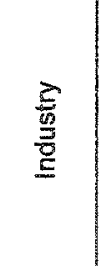 & 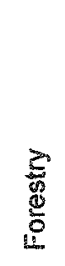 & 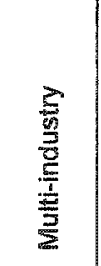 & 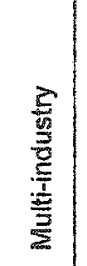 & 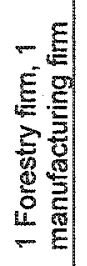 & 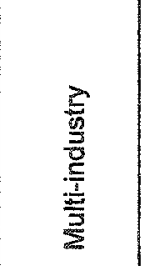 & 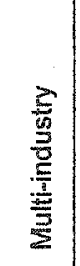 & 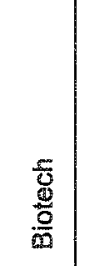 & 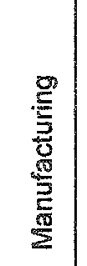 & 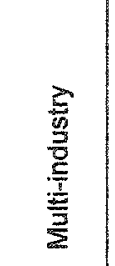 & 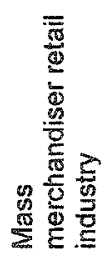 \\
\hline 兽 & $\stackrel{8}{2}$ & \% & ळ్ & ळ్ & 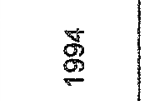 & $\stackrel{2}{2}$ & $\begin{array}{l}\text { 吕 } \\
\stackrel{8}{\circ}\end{array}$ & ষ্ণ & 亏్ & ઠ̊ํํ \\
\hline 总 & 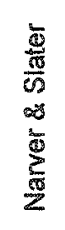 & 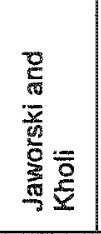 & 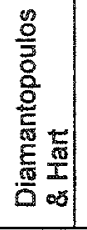 & 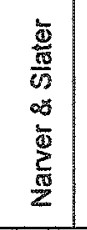 & 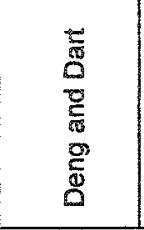 & 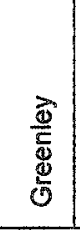 & 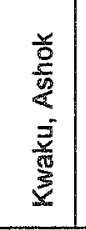 & 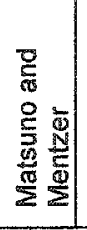 & $\begin{array}{l}\text { 黑 } \\
\text { 焉 }\end{array}$ & $\begin{array}{l}\bar{\pi} \\
\frac{0}{0} \\
0 \\
\frac{0}{0} \\
Z\end{array}$ \\
\hline
\end{tabular}


Narver and Slater's 1994 study was focused on testing the moderating effect of Jaworski and Kohli's [1993】 environmental variables, with special interest on competitive intensity. Their study was based on 107 SBU's in two US organizations, one in the forestry industry and the other of the manufacturing industry. However, neither Jaworski and Kohli [1993】 nor Narver and Slater [1994] found a relationship between the environmental variables and the link between market orientation and performance. Narver and Slater [1994], thus concluded that environmental variables are transient and that a market orientation is beneficial regardless of the condition of the environmental factors.

In contrast, Diamantopolus and Hart [1994] found mixed relationships between the environmental variables and both market orientation and performance. They found some influence of market turbulence and competitive intensity, but of the "demand" factor, they found that the relationship is opposite to that suggested by Jaworski and Kolhi [1990]. i.e. the higher the overall market demand, the stronger the link between market orientation and performance. Greenley also found mixed results. He found that market furbulence and technological turbulence affect the link, but not demand. Conversely, Kwaku and Ashok [1998] found a moderating effect of technological turbulence and demand, but none for competitive intensity. Finally, Harris [2001] only found significant moderating effects of competitive intensity and market turbulence.

In summary, the only area where most authors do not agree is the moderating effect of environmental variables on the market orientation - 
performance link. This has serious implications if a company is to decide whether a market orientation is preferred given the condition of surrounding environmental variables.

Additionally, no study specifically used the telecommunications industry as sampling frame, an industry which has very peculiar characteristics and a history which differentiates it in countless aspects from the rest of the industries in Canada and the world.

\subsection{Literature summary}

In the last few decades there have been successful efforts by several authors to find empirical evidence of a positive link between the degree of market orientation of a company and their business performance. Of the ten empirical studies referenced in this research, seven report a positive link between market orientation and business performance.

These studies use two main measurement scales to measure market orientation, the MARKOR [Jaworski et al,1993] and the MKTOR scale [Narver and Slater, 1990]. Other authors have modified these scales to improve them in various aspecis.

The market business orientation may be associated, either directly or through a moderating effect, with specific environmental factors such as market 
turbulence, competitive intensity, technological turbulence, and overall market demand.

Business performance can be measured using objective or subjective methods. Whether subjective or objective, different authors use different measures of performance including performance relative to company objectives, performance relative to competition, sales growth, new product success, profitability, return on assets (ROA), market share growth and return on investment (ROI). Due to diverse issues discussed in previous sections, the ones that are most pertinent for this research are performance relative to company objectives, performance relative to the competition and sales growth.

The telecommunications industry experienced high demand at the end of the $20^{\text {th }}$ century and thus may not have required a market oriented focus to be highly profitable [Lenain 2003]. However, due to a telecommunications equipment glut and unrealized end user demand at the turn of the millennium, telecommunications equipment manufacturers faced very limited demand from service providers, a high level of competition from hundreds of startups with thousands of innovations, and ever changing technological and market related elements [Lenain 2003, Steinke 2003]. If a link is found beween environmental characteristics and the Market Orientation - Performance continuum, these factors may well play a critical role in the preferred, most effective orientation strategies of telecommunication firms. 


\section{THEORETICAL FRAMEWORK}

\subsection{Research Objectives}

It is clear from the literature review that there is considerable empirical evidence supporting a positive relationship between market orientation and business performance. However, the few authors who have examined the role of the moderating effects of environmental variables have found results that differ from one another. Finding a clear effect of these environmental variables on the market orientation - performance link is critical in order to assess whether certain industries may be significantly assisted by a market orientation given the current environmental factors surrounding them.

At the turn of the millennium, the telecommunications industry may be suffering from a very characteristic mix of environmental factors, such as high technological turbulence and competitive intensity and very low overall market demand, that may affect the market orientation - performance link. With a deeper understanding of the environmental influence on the link between market orientation and performance, it may be easier to analyze the current state of the telecommunications industry and recommend changes in orientation strategies if needed.

Thus this research has four main objectives: 
1. To obtain further empirical evidence supporting a link between a market orientation and business performance. This will be done on a multiindustry.

2. Canadian sample to ascertain the applicability of this relationship over all types of industries, with particular concern for the uniqueness of the telecommunications industry.

3. To explore the pattern of influence of the environmental factors on the market orientation - business performance link. This is also done on a multi-industry Canadian sample to also ascertain the applicability of this relationship over all types of industries, with particular concern for the uniqueness of the telecommunications industry.

4. To understand and ascertain the degree of market orientation of the telecommunications manufacturing industry and the environmental factors affecting it.

5. Given the findings, develop recommendations for companies in the telecommunications industry concerning a preferred orientation strategy to ensure satisfactory business performance

\subsection{Research Model}

This study will base itself on the three models shown in Figure 3 and on the variables listed in Table 6. 
Figure 3. Models to be used for this research

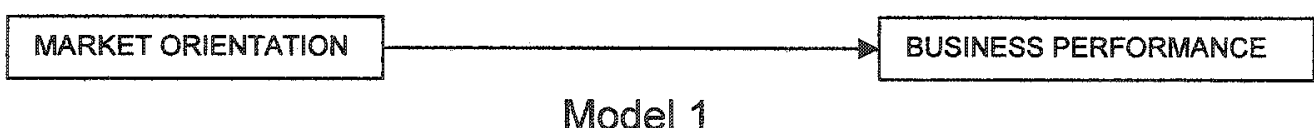

\section{Model 1}

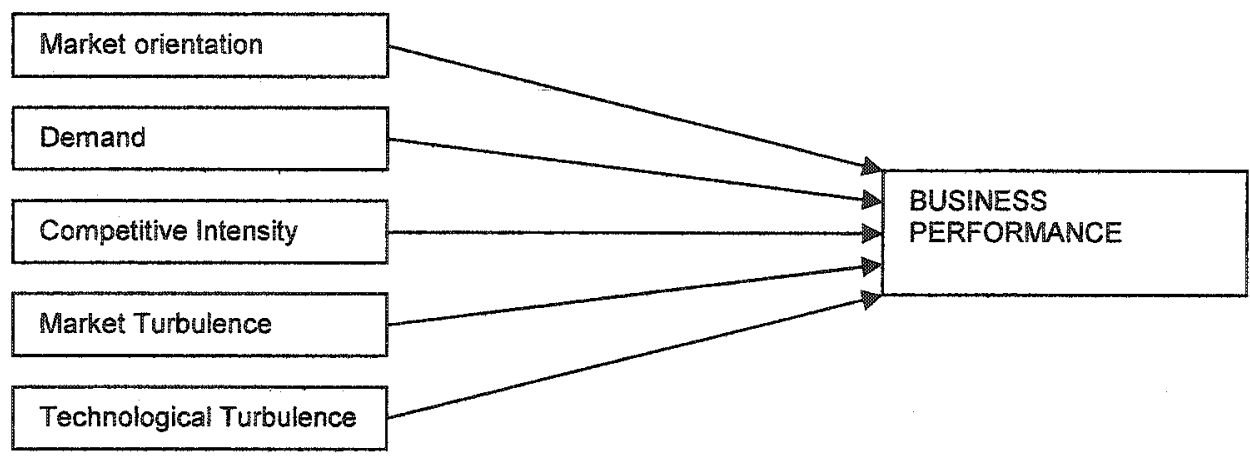

Model 2

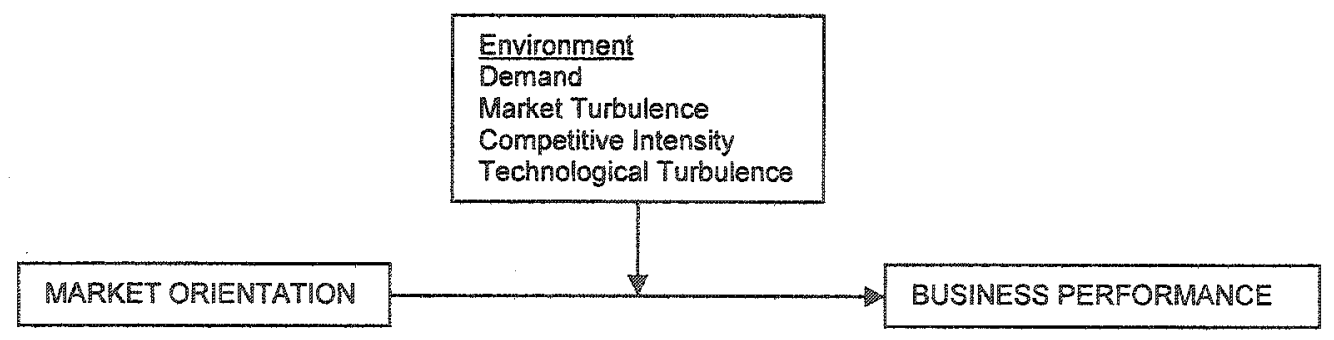

Model 3 
Table 6. List of variables

Model 1

\begin{tabular}{|c|c|c|}
\hline Independent Variables & Moderating Variables & Dependent Variables \\
\hline - Market orientation & --- & $\begin{array}{l}\text { Performance relative to } \\
\text { company objectives } \\
\text { - Performance relative to the } \\
\text { competition } \\
\text { - Sales growth } \\
\text { - Market share growth }\end{array}$ \\
\hline
\end{tabular}

Model 2

\begin{tabular}{|l|l|l|}
\hline Independent Variables & Moderating Variables & Dependent Variables \\
\hline - Market orientation & & - Performance relative to \\
- Overall market demand & & company objectives \\
- Market turbulence & Performance relative to the \\
- Competitive Intensity & - & competition \\
- Technological & $-\begin{array}{l}\text { Sales growth } \\
\text { turbulence }\end{array}$ & - Market share growth \\
\hline
\end{tabular}

\section{Model 3}

\begin{tabular}{|c|c|c|}
\hline Independent Variables & Moderating Variables & Dependent Variables \\
\hline $\begin{array}{l}\text { Market orientation } \\
\text { Overall market demand* } \\
\text { Market turbulence* } \\
\text { Competitive Intensity } \\
\text { Technological } \\
\text { turbulence* }\end{array}$ & $\begin{array}{l}\text { Overall market demand } \\
\text { Market turbulence } \\
\text { Competitive Intensity } \\
\text { Technological } \\
\text { turbulence }\end{array}$ & $\begin{array}{l}\text { Performance relative to } \\
\text { company objectives } \\
\text { Performance relative to the } \\
\text { competition } \\
\text { Sales growh } \\
\text { Market share growth }\end{array}$ \\
\hline
\end{tabular}

* Environmental variables are independent variables when they are not moderating variables 
The following hypotheses will be tested in meeting the objectives and testing the models.

H1: The greater the market orientation of a company, the higher its business performance.

This is the main hypothesis on which all the market orientation research is based and applies to all industries in Canada, not just the telecommunications industry. It tests model 1 and is also fundamental to models 2 and 3 , and it will be used to meet the first objective of this research.

H2a: The greater the overall market demand experienced by the company, the weaker the relationship between market orientation and business performance.

It is expected that under very high overall market demand conditions, a market orientation may not be as necessary to sell products and be profitable. Possible causes of high demand of a product are many, and include a temporary reduction in price, a shortage of the product, a new innovation awakening a latent demand in the consumer, etc. Any of these causes will make a potential consumer less discerning in his buying-decision process and more anxious to purchase. Therefore the seller will require less marketing efforts to influence the buyer to carry out a purchase. This hypothesis is part of the test of model 3 and will be used to meet the second objective. 
H2b: The greater the market turbulence, the stronger the relationship between a market orientation and business performance.

In conditions where market preferences remain unchanged for long periods, it is expected that little market research will be required to maintain sales and profitability. When market preferences change rapidly, market attention will be required to respond to the changes and thus maintain competitiveness. Thus in markets with high turbulence, a stronger market orientation will be more effective. However, it is also possible that if market preferences are unstable enough, then market orientation may prove impractical given that the speed of changes in customer requirements makes market research impossible. This hypothesis is part of the test of model 3 and will be used to meet the second objective.

H2c: The greater the competitive intensity, the stronger the relationship between a market orientation and business performance.

Greater competition will require a more in-depth knowledge of market preferences in order to provide a more likable offering, and thus maintain competitiveness. Thus in a competitive market, a stronger market orientation may be more effective. This hypothesis is part of the test of model 3 and will be used to meet the second objective. 
H2d: The greater the technological turbulence, the weaker the relationship between a market orientation and business performance.

In high tech industries, including the telecommunications industry, new innovative products may satisfy previously unidentified customer wants and needs. These products may result from pure R\&D efforts relying on little to no market input. Thus in markets with high technological turbulence, a market orientation may not be as necessary. This hypothesis is part of the test of model 3 and will be used to meet the second objective.

Due to the alternate model proposed by some researchers (model 2 in Figure 3), the following alternate hypotheses are formulated:

H3a: The overall market demand experienced by the company affects its business performance.

H3b: The competitive intensity experienced by a company affects its business performance.

H3c: The technological turbulence experienced by a company affects its business performance.

H3d: The market turbulence experienced by a company affects its business performance.

This hypothesis will be used to meet the second objective. 
According to hypotheses 2 ( $a, b$ and $c$ ), the telecommunications industry may require a stronger market orientation in order to weather the environmental factors currently affecting it, particularly very low overall market demand and high competitive intensity. On the other hand, it may not require a strong market orientation given that it is in a constant state of high technological turbulence. For this reason it is important to confirm whether the telecommunication manufacturing industry is experiencing conditions of environmental factors different from those facing the rest of the manufacturing industry of Canada in order to recommend a proper level of market orientation.

H4a: The telecommunications industry is currently experiencing below average overall market demand.

H4b: The telecommunications industry is currently experiencing above average competitive intensity.

H4c: The telecommunications industry is currently experiencing above average technological turbulence.

Hypotheses $4(a, b$ and $c)$ will be used to meet the $3^{\text {rd }}$ objective and subsequently the $4^{\text {th }}$ objective.

To recommend a successful market orientation strategy, it is important to verify current levels of market orientation of companies in the telecommunications industry. Given the unprecedented high demand experienced at the end of the $20^{\text {th }}$ century, it is expected that the orientation of 
telecommunication companies may be that of a production orientation or sales orientation, and not one of high market orientation.

To test this assumption, the market orientation of the telecommunications industry must be compared to the rest of the manufacturing industry in order to determine whether it is below, above or at the same level.

H5: The telecommunications industry has a market orientation lower than the rest of the manufacturing industry.

This hypothesis will also be used to meet the $3^{\text {rd }}$ objective and subsequently the $4^{\text {th }}$ objective. 


\section{RESEARCH METHODOLOGY}

This section describes how this research gathered evidence to test the different models and the hypothesis proposed in the previous chapters.

\subsection{Research design}

This research was based on a single cross-sectional observation of the manufacturing industry of Canada and the telecommunications equipment manufacturing industry of Canada. To test the proposed hypotheses, this observation consisted of a self administered questionnaire sent to qualified respondents to collect primary data on the variables listed in Table 6. This method was chosen due to its relative ease of implementation and statistical analysis compared to open-ended interviews, and because it is similar to the methodology used by all but one [Noble et al, 2002] of the previous studies listed in Table 5.

\subsection{Sample}

The overall unit of analysis for this research was Canadian firms. The sample frame consisted of Canadian manufacturers and Canadian telecommunications manufacturers. More specifically, the NAICS codes $31-33$ were used to identify manufacturing firms, and NAICS codes 334210,334220 
and $334290^{4}$ to identify telecommunications related firms. It is important to note the latter is a subset of the former. Throughout this report, the telecommunication group refers to firms in the telecommunications industry and the manufacturing group refers to firms in the manufacturing industry excluding those firms in the telecommunications industry.

Given these codes, a list of firms and contacts was obtained from the 2004 Scott's Select Business Directory. The 2004 Scott's Select Business Directory is a yearly publication containing up-to-date contact information of companies in Canada. It contains contact information for each company's top management employees, including owners, presidents, CEO's, etc., as well as company size and yearly sales information. The database includes 115,000 companies. Although it does not include all companies, its size indicates broad representativeness and usefulness for purposes of this study. It is a highly regarded source as evidenced, for example, by its use by Industry Canada as a reference source in its website industry notes on e-commerce in various sectors ${ }^{5}$.

An initial search of the Canadian Capabilities website $^{6}$, hosted by Strategis Canada, indicated that the population size of the telecommunication

\footnotetext{
434210: Telephone Apparatus Manufacturing 334220: Radio and Television Broadcasting and Wireless Communications Equipment Manufacturing 334290: Other communications equipment manufacturing 5 http://strategis.ic.gc.ca/epic/internet/inecomcome.nsf/en/qy0006le.html?OpenDocument\&source=Headlines 6 http $/ /$ strategis.ic.gc.ca/cgi-bin/sc_coinf/ccc/cccsrch?submit_srchscreen=detalialang=e\&search_screen=cc
} 
group available through them is comprised of 695 companies $^{7}$, and the manufacturing group is comprised of $10650+$ companies $^{8}$. Given the finite population size for the telecommunication group the response rate should be of at least 84 companies for reasonable reliability and confidence ${ }^{9}$. The sample size used for the telecommunication group was of 531 companies; of which 16 were returned because the recipient was no longer at that address, thus the true sample size was of 515 companies. Of these, top management personnel of 73 companies responded the questionnaire, resulting in a $14.2 \%$ response rate and an error of $5.4 \%$ (i.e. 0.27 out of 5 from the 5 point scale).

In the case of the manufacturing group the response should be of at least 95 companies. The sample size used for the manufacturing group was of 545 companies; of which 6 were returned because the recipient was no longer at that address, thus the true sample size was of 539 companies. Of these, top management personnel of 76 companies responded the questionnaire, resulting in a $14.1 \%$ response rate and an error of $5.6 \%$ (i.e. 0.28 out of 5 from the 5 point scale).

\footnotetext{
${ }^{7}$ The search string used was the word on the Strategis website was "telecommunications" and businesses with $\$ 1.00+$ in sales, as of January 9,2004

${ }^{8}$ The code used was SIC E code $E$ (manufacturing), for businesses with $\$ 1.00+$ in sales, as of August 19, 2003

"Sample sizes where calculated using the "sample size equation for finite populations" formula and the "actual sample" formula from Davis [2000], using a variance estimate of 1.25 ( $\sigma=$ range $/$ 4 , [Davis, 2000], where range is 5 , from the 5 point scale), an allowable error of $5 \%(0.25$ is $5 \%$ of 5 , from the 5 point scale) and a 2 score of $1.96(95 \%)$.
} 
In total, of the 1076 questionnaires sent, 149 were retumed completed and 22 returned because the recipient was no longer at that address, resulting in a $14.1 \%$ total response rate.

A questionnaire was sent to all contacts in the business directory list corresponding to the telecommunication group. For the manufacturing group, 2111 contacts existed in the business directory. The list was filtered by keeping only those companies with their President's contact information. Further scrutinizing of the list was done to find duplicated contacts and missing or erred information. The reduced list of 992 contacts was further trimmed down to 539 contacts by maintaining only those contacts with the last name starting with $A$ to K.

This research used a single respondent from each company, versus surveying multiple respondents.

The type of respondents contacted for the telecommunication group was the highest executive in the contact list for that company. The contact list for the manufacturing group had enough contacts to allow only presidents to be contacted, which are considered to have a complete view of the company's product strategy and business orientation. In total, $65 \%$ of respondents were presidents, $11 \%$ were general managers, $7 \%$ were CEO's, $5 \%$ were Vice presidents, $1 \%$ were owners, $1 \%$ were directors, $1 \%$ were Controllers, $1 \%$ were Chairmen, $1 \%$ were CFO's and the last $7 \%$ were a combination of other types of managers and job functions. 


\subsection{Survey design}

This research obtained its data from self administered questionnaires sent through regular mail to the contacts obtained from the sample lists defined previously. See Appendix $\mathrm{C}$ for the full instrument used.

The instrument was a combination of the MARKOR [Jaworski and Kohli, 1993], MKTOR [Narver and Slater's, 1990] and MO [Matsuno, 2000] scales. All these scales were included so as to have as much information from the responses as possible, both for this research as well as for future researchers.

The final instrument used to carry out the final analysis for this study was based on Farrell and Oczkowski's [1997] scale for the following reasons:

- Farrell and Oczkowski's [1997] scale is based on Jaworski et al's [1993] MARKOR scale which is ideal for providing insight into a company's implementation of the market orientation philosophy and its ability to respond to environmental factors [Gauzente 1999].

- It maintains a reasonable balance between the various sub constructs of the MARKOR scale [Jaworski et al's, 1993]

- It improves the goodness of fit of the MARKOR scale [Jaworski et al's, 1993]

- It maintains the itern wording of the MARKOR scale, thus the general essence of the measured construct 
The environmental factors measured where those recommended by Jaworski and Kohli [1990]:

- Market turbulence

- Competitive intensity

- Technological turbulence

- Demand

The measurement scales used to measure these variables where based on those proposed by Jaworksi and Kohli [1993], given that they have been previously tested for goodness of fit. Respondents were asked to estimate the condition of these environmental variables affecting their market.

Due to diverse issues discussed in section 2.5 , the performance variables measured in this research were:

- Performance relative to company objectives

- Performance relative to the competition

- Sales growth

- Market share growth

The performance scales used were based on those proposed by Matsuno [2000] and Matsuno and Mentzer [2000], given that they have been previously tested for goodness of fit.

Besides the scales mentioned previously, the strategy types from Matsuno and Mentzer's [2000] scale were included in the questionnaire, so as to make sure the responses provided useful information for future research. Finally, the 
questionnaire asked respondents for personal information in order to classify them into groups. The personal information requested was:

- Current Position

- Number of Employees

- Annual sales in Canadian Dollars

- Year established

- Primary product/service offered by the company

Additionally, an open ended question was included so that the respondent could add their comments regarding the major trends or factors currently affecting their industry or any other topics of the survey. Their responses are discussed in section 5.6 .

\subsubsection{Pre test}

The first draft of the scale listed in Appendix A was pre-tested using a small convenience sample of respondents to assure that the questionnaire could be answered with clarity and was not difficult or time consuming. The sample of respondents was composed of a CEO of an IT company, a Marketing Manager of a large telecommunications manufacturer, a Vice President of a telecommunications company, and a marketing expert.

Feedback from the test subjects resulted in several changes to the questionnaire, listed below. 
To begin with, the open-ended question initially situated at the beginning of the survey was transferred to the back of the survey since most respondents complained that it required a lot of thought and could deter people from continuing the response of the rest of the questionnaire.

Next, a small preface was introduced at the beginning of the questionnaire to make sure that the respondent understood that:

1. The questionnaire was to be responded according to the respondent's own experiences and not what the company advocated.

2. The survey should be responded by the person who had the most insight into the overall business strategy and operations of the company.

One of the most repeated complaints was that the questionnaire was too long. For this reason, changes where done to the final questionnaire to make it shorter so as to reduce the probability that a respondent would not respond due to the length of the scale [Jaworski et al, 1993, Farrell and Oczkowski, 1997].

Questions 5 and 7, listed in Appendix A, both refer to how the company is concerned in understanding the external factors affecting it, therefore they where combined into a single question:

"In this company, we frequently collect and evaluate general macroeconomic and social trends information (e.g. interest rate, exchange rate, 
GDP, industry growth rate, inflation rate, environmental concerns, emerging lifestyles) that might affect our business".

Questions 33, 34, 35, 38 and 39, listed in Appendix A, all deal with whether the company has interdepartmental meetings to discuss and disseminate environmental and customer information. The concept measured is repeated because the questions come from different scales (MO [Matsuno, 2000], MKTOR [Narver and Slater, 1990] and MARKOR [Jaworski and Kohli, 19931). Thus the questions were combined into one single question that encompassed all five.

"We regularly have interdepartmental meetings to discuss customer experiences and future needs, and market trends and developments (customers, competition, suppliers, regulatory requirements, etc.)"

Question 26, listed in Appendix A, only asks about how well the activities of the different departments are coordinated, but does not relate them to a market orientation or a customer focus. Question 36, listed in Appendix A, on the other hand, encompasses the former question with the addition of a market focus. The latter question is MKTOR's [Narver and Slater, 1990] version of the former (MARKOR [Jaworkki and Kohli, 1993], MO [2000]). Since the MKTOR 
question asks the same concept as the MARKOR question and more, the MARKOR question was deleted.

Finally, the questions where categorized and grouped depending on whether they belonged to the intelligence generation, responsiveness, or intelligence dissemination components defined by Jaworski and Kohli [1993].

With the equivalences between Jaworski and Kohli's [1993] components and Narver and Slater's [1990] components suggested by Diamantopoulus and Hart [1993], MKTOR-based questions were distributed into their respective component grouping.

\subsection{Mailings}

An envelope was sent to each respondent including the following documents:

1. A cover letter inviting the participation of the respondents and introducing and explaining the research, its purpose and benefits. (see Appendix D for a sample cover letter)

2. The questionnaire to gather the required information to meet the study objectives (see Appendix $\mathrm{C}$ for a sample questionnaire)

3. A postage-paid addressed envelope for returning the questionnaire.

4. A separate postage-paid post-card that allowed the respondent to optout of the study, or to report their participation and to ask for the results 
of the study when they became available (see Appendix $F$ for a sample post card).

Measures were taken to maintain the confidentiality and anonymity of the respondent. The questionnaire did not in any way identify the respondent, and the return post card could not be linked to the questionnaire.

The respondents were given a two-week deadline to return the completed questionnaire after its receipt. Two weeks after the first mailing, another questionnaire was sent to those contacts that had not yet responded. The respondents were given another two-week deadline to return the second completed questionnaire after its receipt.

The second mailing included all four elements stated above, but with a new cover letter (see Appendix $E$ for a sample cover letter) that politely reminded the respondents of the importance of his participation and to encourage them once again to answer and return the questionnaire.

To differentiate between both groups of respondents (telecommunication and manufacturing), a small mark was placed at the top right hand corner of the last page of the questionnaire only for those questionnaires sent to telecommunications companies. 


\subsection{Cover letter}

The cover letter sent to each respondent (see Appendix D for a sample cover letter) included:

- The name, affiliation, and means of contacting the principal investigator and supervisor with any questions or comments

- Date and signatures of the principal investigator and supervisor

- An invitation to participate in the research project

- A comprehensive statement of the aim of the study

- Instructions to answer the enclosed questionnaire and the time expected to fill it out

- Confidentiality and security of the respondents identity and answers

- Indications on how anonymity would be ensured and securely handled

- Clear statement of voluntary participation and the right of the participant to refuse to answer any questions, and

- The benefits arising from their participation in the study

\subsubsection{Recurn post card}

The postage-paid post card (see Appendix F for a sample post card) included in the package allowed the respondent to indicate their acceptance or 
declination to answer the questionnaire, as well as allowed them to ask for the receipt of the research results once they became available.

The post card included the respondent's contact information and was to be returned separately at the same time that they sent their questionnaire. When they returned the card, the respondent's name was added to a report mailing list or deleted from the original mailing list, depending on what they requested via the post-card.

\subsubsection{Returned questionnaires}

The returned questionnaires were received directly by the thesis supervisor and their answers were transferred from the questionnaires to an SPSS database by the graduate student himself.

Those contacts that did not return their questionnaire were analyzed to find out possible differences between respondents and non-respondents.

\subsubsection{Results for respondents}

Once the analysis of the data was done and solutions obtained from the research, the results were sent to each respondent that explicitly asked for them via the post-card. 
The results sent to respondents were sent via an envelope that included a cover letter explaining the purpose of the study and a summary of the results of the study, and a brief document with a more detailed description of the results of the study. See Appendix $G$ for a sample cover letter to respondents and Appendix $\mathrm{H}$ for a sample document detailing the results of the study. 


\section{DATA ANALYSIS AND RESULTS}

This section provides the analysis methods and results from the study.

\subsection{General statistics}

\subsubsection{Response levels and representativeness of the sample}

There were 152 questionnaires returned in total from both mailings - 77 were from the manufacturing group and 75 from the telecommunication group (see Table 7).

Table 7. Telecommunication group vs. manufacturing group responses

\begin{tabular}{|c|c|c|c|}
\hline & & Frequency & Percent \\
\hline \multirow[t]{3}{*}{ Valid } & manufacturing & 77 & 50.7 \\
\hline & telecommunication & 75 & 49.3 \\
\hline & Total & 152 & 100.0 \\
\hline
\end{tabular}

All 152 questionnaires responded to all the 5-point Likert scale questions. The data in the SPSS database were checked for outliers to find possible mistakes in the data entry. No outliers were found.

Of the personal questions asked of the respondents, only two of the respondents did not answer the question regarding the number of employees in their company, thirteen did not answer the question about the company's annual 
sales, and one did not respond to the question about the year the company was established (see Table 8).

The number of employees of the companies that responded varied from 4 to 800 employees. The mean was 102 employees and the median 45 employees.

Table 8. Personal question responses statistics

\begin{tabular}{|c|c|c|c|c|c|}
\hline & & $\begin{array}{l}\text { number of } \\
\text { employees }\end{array}$ & annual sales & $\begin{array}{r}\text { yeaı } \\
\text { establis }\end{array}$ & ed \\
\hline & Valid & 150 & 139 & & 51 \\
\hline & Missing & 2 & 13 & & 1 \\
\hline \multicolumn{2}{|c|}{ Mean } & 102.09 & 18.67 & 19 & $i .44$ \\
\hline \multicolumn{2}{|c|}{ Median } & 45.00 & 7.00 & 19 & .00 \\
\hline \multicolumn{2}{|c|}{ Range } & 796 & 250 & & 12 \\
\hline \multicolumn{2}{|c|}{ Minimum } & 4 & 0.250 & & 390 \\
\hline \multicolumn{2}{|c|}{ Maximum } & 800 & 250 & & 302 \\
\hline
\end{tabular}

The annual sales of the companies that responded varied from less than $\$ 1$ million to $\$ 250$ Million dollars. The mean was $\$ 18.7$ Million dollars and the median was $\$ 7$ Million dollars.

Moreover, the oldest company that responded was established in 1890 and the youngest was established in 2002.

To find out if the mix of companies received from the survey was representative of the entire population of companies in Canada, both the distribution of number of employees and the distribution of annual sales results 
were compared to the entire population of companies in Canada. The data for the entire population of companies in Canada was obtained from the Strategis Canada database ${ }^{10}$.

The data for number of employees shown in Figure 4 shows similar distribution between the data obtained in the survey and the data from the Strategis website, except for companies of 10 employees or less. This may be because the business database used for the survey did not have contact information for very small companies that have a small number of employees, and whose contact information is not readily available to business databases like the Scotts business directory. Additionally, the company with the most number of employees had 800 employees; consequently, companies with more than 800 employees are not represented and results may not apply to these very large companies. However, there are few companies of this size in Canada. Industry Canada notes that only $0.2 \%$ of goods and services producing companies have greater than 500 employees. ${ }^{11}$

The data for annual sales shown in Figure 5 shows the same variation in distribution as the data for number of employees. Companies with less than a million dollars in sales were less represented among the survey respondents compared to a high number of companies reported by the Strategis website. Once again, this may be because the business database used for the survey did

\footnotetext{
to hitp://strategis.ic.gc.ca/cgi-oin/sc_coinf/cccicccsrch?submit_srchscreen=detail\&lang=e\&search_screen=cc ${ }^{11} \mathrm{http} / /$ strategis.ic.gc.ca/sc_ecnmy/sio/ciseste.html
} 
not have micro companies, with few sales, whose contact information is not readily available to such business databases.

Figure 4. Number of employees of respondent companies vs. Canadian population of businesses

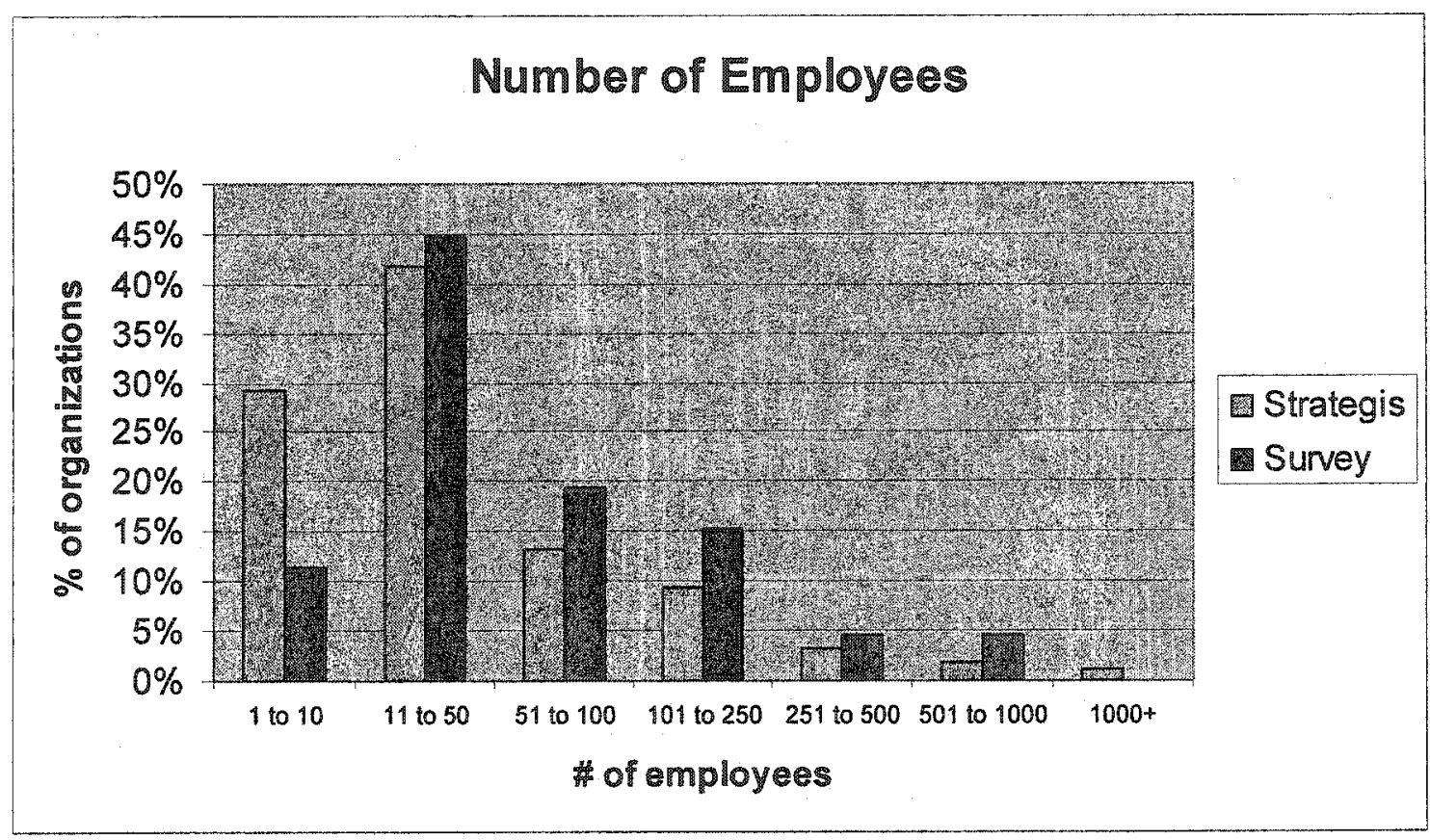

Industry Canada ${ }^{12}$ defines a small manufacturing company as a company with fewer than 100 employees. So for this research, we will consider our sample as representative of small, medium and large corporations in Canada, but not of micro companies of Canada, with less than ten employees and less than a million dollars in sales. This is an obvious limitation of the results obtained for the study and will have to be accounted for when interpreting the results.

\footnotetext{
${ }^{12}$ http://strategis.ic.gc.calepic/internetinsbrp-rppe.nsflen/rd00668e.html
} 
Figure 5. Annual sales of respondent companies vs. Canadian population of businesses

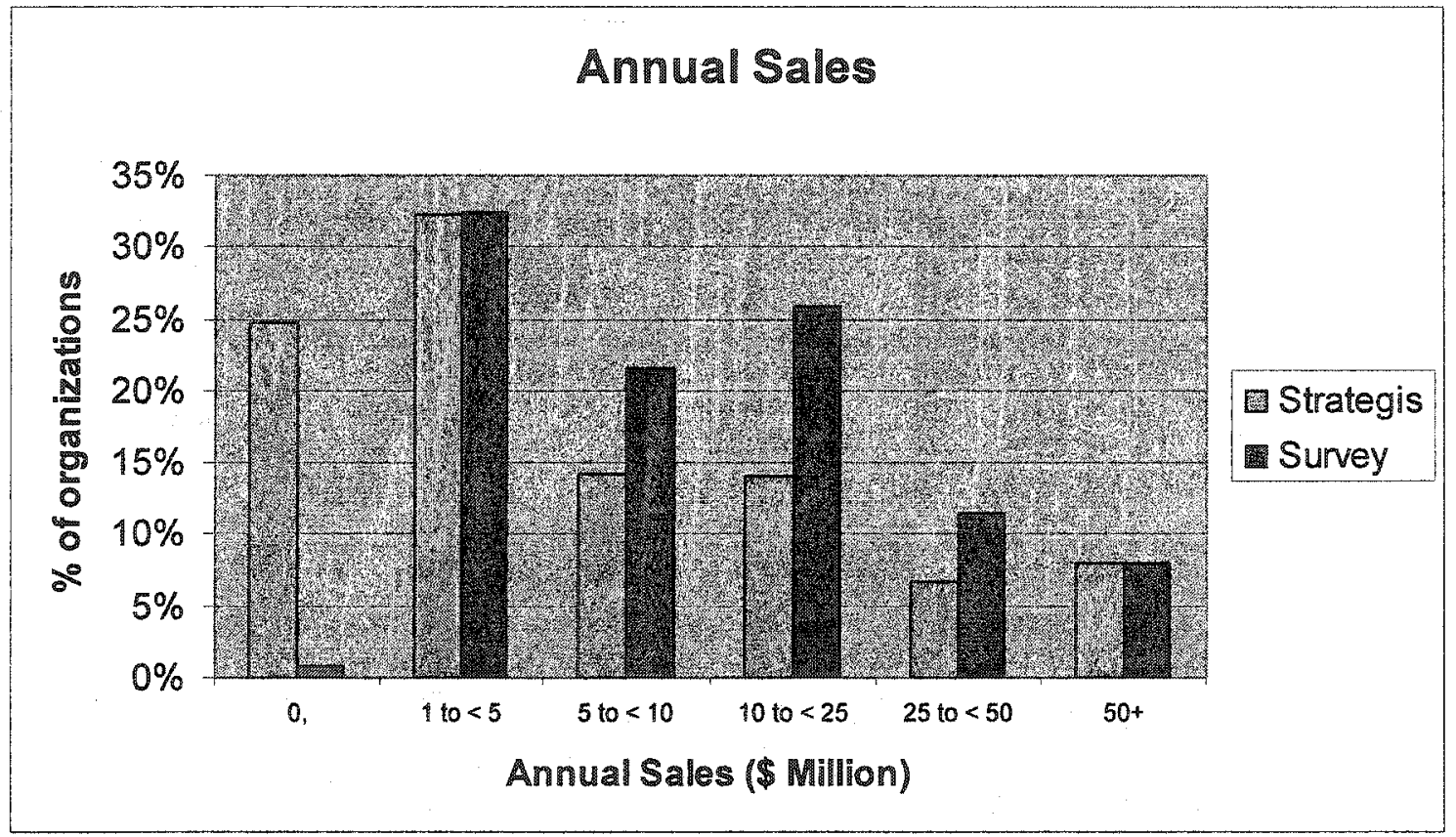

Finally, the results showed that 85 companies (56\%) answered on the first round of the mailings and 67 companies (44\%) responded on the second round of mailings (see Table 9).

Comparisons beiween first and second round respondents using t-tests on the following variables found no significant results (see Table 10) regarding:

- Each individual performance variable:

- Performance relative to company objectives

- Performance relative to the competition

- Sales growth 
- Market share growth

- Number of́ employees

- Annual sales

- Market orientation mean

- Market Turbulence mean

- Competitive intensity mean

- Technological turbulence mean

- Overall market demand mean

Table 9. First vs. Second round responses

\begin{tabular}{|c|c|c|c|}
\hline & & Frequency & Perı nt \\
\hline \multirow[t]{3}{*}{ Valid } & 1 & 85 & 5.9 \\
\hline & 2 & 67 & 4.1 \\
\hline & Total & 152 & 0.0 \\
\hline
\end{tabular}

A t test between respondents and non-respondents with respect to annual sales and number of employees showed no significant difference between them (see Table 11). The annual sales and number of employees from nonrespondents was obtained from the Scott's Business Directory originally used to obtain the contact information for the sample frame. 
Table 10. $t$ tests to compare 1 st and 2 nd round respondents

\begin{tabular}{|l|l|}
\hline & $t(\mathbf{s i g .})$ \\
\hline Performance relative to company objectives & $-0.55(0.59)$ \\
\hline Performance relative to competitors & $1.02(0.31)$ \\
\hline Sales growth & $0.16(0.88)$ \\
\hline Market share growth & $0.98(0.33)$ \\
\hline Number of employees & $-0.13(0.90)$ \\
\hline Annual sales & $-1.06(0.29)$ \\
\hline MOMEAN & $0.72(0.47)$ \\
\hline MKMTMEAN & $0.74(0.46)$ \\
\hline MKCPMEAN & $-0.82(0.41)$ \\
\hline MKTTMEAN & $1.44(0.15)$ \\
\hline MKDMMEAN & $1.39(0.17)$ \\
\hline
\end{tabular}

Table 11. t-test between respondents and non-respondents

\begin{tabular}{|l|l|l|l|l|l|}
\hline \multicolumn{2}{|c|}{} & Mean & $\sigma$ & $t$ & Sig. \\
\hline \multirow{2}{*}{$\begin{array}{l}\text { Number of } \\
\text { employees }\end{array}$} & Respondents & 102.09 & 154.42 & 1.50 & 0.14 \\
\cline { 2 - 6 } & $\begin{array}{l}\text { Non- } \\
\text { respondents }\end{array}$ & 81.96 & 140.45 & & \\
\hline \multirow{3}{*}{ Annual sales } & Respondents & 18.67 & 33.06 & 1.61 & 0.11 \\
\cline { 2 - 5 } & $\begin{array}{l}\text { Non- } \\
\text { respondents }\end{array}$ & 15.23 & 17.82 & & \\
\hline
\end{tabular}


Results from a comparison of early and late respondents is often used to suggest the similarity of respondents to non-respondents. In this case, the comparison indicates no significant differences. Combined with information confirming the similarity of the sample on size to the Canadian population of small, medium and large companies, the study results can be expected to be a valid representation of Canadian businesses.

\subsubsection{Measures of dependent and independent variables}

The mean for all respondents of both dependent and independent variables resulted in values above 3 , except for the overall market demand variable (mkdmmean) (see Table 12). This suggests that, on average, most companies have a high market orientation and experience high market turbulence, competitive intensity, technological turbulence, and performance, and low overall market demand.

This last conclusion seems to provide initial support for Hypothesis $4 a$. However, as can be seen from Table 12 the low market demand is attributed to the manufacturing group and not the telecommunication group. This will be discussed in section 5.5 .1 . 
Table 12. Means of dependent and independent variables

\begin{tabular}{|c|c|c|c|c|c|c|}
\hline & \multicolumn{2}{|c|}{ All respondents } & \multicolumn{2}{|c|}{$\begin{array}{l}\text { Manufacturing } \\
\text { Group }\end{array}$} & \multicolumn{2}{|c|}{$\begin{array}{l}\text { Telecommunication } \\
\text { group }\end{array}$} \\
\hline & Range* & $\operatorname{Mean}(\sigma)$ & Range* & $\operatorname{Mean}(\sigma)$ & Range ${ }^{*}$ & Mean (o) \\
\hline $\begin{array}{l}\text { Market } \\
\text { orientation }\end{array}$ & $2.11-5$ & $\begin{array}{l}3.77 \\
(0.64)\end{array}$ & $2.11-5$ & $\begin{array}{l}3.78 \\
(0.63)\end{array}$ & $2.11-5$ & $3.76(0.66)$ \\
\hline $\begin{array}{l}\text { Market } \\
\text { turbulence }\end{array}$ & $1-4.6$ & $\begin{array}{l}3.16 \\
(0.81)\end{array}$ & $1-4.4$ & $\begin{array}{l}3.09 \\
(0.82)\end{array}$ & $1.2-4.6$ & $3.23(0.81)$ \\
\hline $\begin{array}{l}\text { Competitive } \\
\text { intensity }\end{array}$ & $\begin{array}{l}1.67- \\
4.83\end{array}$ & $\begin{array}{l}3.12 \\
(0.77)\end{array}$ & $\begin{array}{l}1.67- \\
4.67\end{array}$ & $\begin{array}{l}3.21 \\
(0.80)\end{array}$ & $\begin{array}{l}1.67- \\
4.83\end{array}$ & $3.02(0.73)$ \\
\hline $\begin{array}{l}\text { Technological } \\
\text { turbulence }\end{array}$ & $1-5$ & $\begin{array}{l}3.56 \\
(1.04)\end{array}$ & $1-5$ & $\begin{array}{l}3.37 \\
(1.08)\end{array}$ & $1-5$ & $3.76(0.98)$ \\
\hline Demand & $1-5$ & $\begin{array}{l}2.85 \\
(1.02)\end{array}$ & $1-4.5$ & $\begin{array}{l}2.64 \\
(0.91)\end{array}$ & $1-5$ & $3.06(1.08)$ \\
\hline $\begin{array}{l}\text { Performance } \\
\text { mean }\end{array}$ & $1.5-5$ & $\begin{array}{l}3.71 \\
(0.77)\end{array}$ & $1.5-5$ & $\begin{array}{l}3.71 \\
(0.80)\end{array}$ & $2-5$ & $3.72(0.74)$ \\
\hline $\begin{array}{l}\text { Performance } \\
\text { relative to } \\
\text { company } \\
\text { objectives }\end{array}$ & $2-5$ & $\begin{array}{l}3.68 \\
(0.95)\end{array}$ & $2-5$ & $\begin{array}{l}3.70 \\
(0.99)\end{array}$ & $2-5$ & $3.67(0.98)$ \\
\hline $\begin{array}{l}\text { Performance } \\
\text { relative - } \\
\text { competition }\end{array}$ & $2-5$ & $\begin{array}{l}3.98 \\
(0.75)\end{array}$ & $2-5$ & $\begin{array}{l}3.95 \\
(0.76)\end{array}$ & $2-5$ & $4.01(0.74)$ \\
\hline Sales growth & $1-5$ & $\begin{array}{l}3.61 \\
(1.02)\end{array}$ & $1-5$ & $\begin{array}{l}3.64 \\
(1.01)\end{array}$ & $1-5$ & $3.59(1.04)$ \\
\hline $\begin{array}{l}\text { Market share } \\
\text { growth }\end{array}$ & $1-5$ & $\begin{array}{l}3.58 \\
(0.97)\end{array}$ & $1-5$ & $\begin{array}{l}3.55 \\
(1.11)\end{array}$ & $2-5$ & $3.61(0.80)$ \\
\hline
\end{tabular}

* Actual observed range. Possible measure range for all variables was 1 to 5

\subsection{Data preparation for hypothesis and model testing}

As mentioned in section 4.3 , the results from this study were derived from the questions from Farrell and Oczkowski's [1997] scale due to reasons discussed in previous sections. Both Harris [2001] and Greenley [1995] use the summated means of all the items constituting a variable to obtain a single item overall impression of each variable, so the following summated means were 
calculated beforehand for each variable that would be used in the analysis. Reverse scaled questions were recoded as necessary before summing.

(See Appendix B for a complete list of variables and the names used in the SPSS calculations)

Table 13. List of single item overall impressions for each variable

\begin{tabular}{|l|l|}
\hline Variable Description & Variable name \\
\hline Market orientation mean & momean \\
\hline Market turbulence mean & mkmtmean \\
\hline Market Competitiveness mean & mkcpmean \\
\hline Market technological turbulence mean & mkttmean \\
\hline Market demand mean & mkdmmean \\
\hline Performance mean & perfmean \\
\hline
\end{tabular}

Histograms were developed for all mean variables to make sure those variables had a relatively normal distribution and did not show obvious bimodal tendencies (see Appendix I, Figure 6 through Figure 11). All variables showed relative normality, except technological turbulence which showed positive skew. None presented bimodal tendencies. 


\subsection{Valdity and reliabing}

To make sure the scales were useful for measuring the intended constructs the scales were tested for reliability and validity.

\subsubsection{Reliability: Cronbach's alpha}

Reliability was measured using the Cronbach's alpha coefficient as suggested by Harris [2001]. Cronbach's alpha can be written as a function of the number of test items and the average inter-correlation among the items. As the average inter-item correlation increases, Cronbach's alpha increases as well. Thus if the inter-item correlations are high, then there is evidence that the items are measuring the same basic construct. High reliability refers to how well the items measure a single unidimensional latent construct, which is why Cronbach's alpha helps measure reliability.

Harris [2001] suggests that a Cronbach's alpha value of 0.7 or above is needed for a scale to be considered reliable. Deng and Dart [1994] reported alphas between 0.72 and 0.78 .

Except for the overall market demand scale, all Cronbach's alphas reported fell well above the value suggested by Harris [2001], thus indicating reliable scales. 
The results for each scale used in this study are listed below (see details in Appendix 1.2):

Table 14. Cronbach's alpha results for each scale

\begin{tabular}{|l|l|l|}
\hline Scale & $\begin{array}{l}\text { Cronbach's } \\
\text { alpha }\end{array}$ & $\begin{array}{l}\text { Number } \\
\text { of items }\end{array}$ \\
\hline Market Orientation & 0.76 & 9 \\
\hline Market turbulence scale & 0.73 & 5 \\
\hline Market competitiveness scale & 0.74 & 6 \\
\hline Market turbulence scale & 0.89 & 4 \\
\hline Market demand scale & 0.59 & 2 \\
\hline Performance & 0.85 & 4 \\
\hline
\end{tabular}

Values for "alphas if item deleted" were calculated for all items in each scale. These values, from now on referred to as the "item deleted alpha" for simplicity, show the Cronbach's alpha value of the scale if a particular item in the scale were not included in the final scale.

For market orientation, technological turbulence and performance scales, all item deleted alphas are lower than the alpha for the complete scale, suggesting that all items should be used for the highest reliable scale respectively.

For the Market turbulence scale, the question "We cater to many of the same customers that we used to in the past" had a higher item deleted alpha than the total alpha for market turbulence scale. This suggests that if the item were to be deleted then the scale would be more reliable. None the less, given 
that the total alpha that includes that item is high enough to consider the scale reliable, the item was not deleted so as to maintain the original scale proposed by Kohli and Jaworski [1990].

For the competitive intensity scale, the question "Our competitors are relatively weak" had a higher item deleted alpha than the total alpha for the competitive intensity scale. This suggests that if the item were to be deleted then the scale would be more reliable. None the less, given that the total alpha that includes that item is high enough to consider the scale reliable, the item was not deleted so as to maintain the original scale proposed by Kohli and Jaworski [1990].

For the overall market demand scale, the Cronbach's alpha reported for the scale is not above the value suggested by Harris [2001] for a reliable scale. However, the Cronbach's alpha calculation is sensitive to the number of items in the scale, so a Cronbach's alpha of approximately 0.6 will be considered satisfactory given that it only contains two items.

\subsubsection{Validity: Convergent and Discriminant validity}

As per Deng and Dar's [1994] method of validity analysis, three types of validity checks where done: Content, criterion and construct. 
Content: According to Deng and Dart [1994], content validity is obtained "if there is general agreement among the subjects and researchers that constituent items cover all aspects of the variables measured". The scales used for this study MARKOR, MO and MKTOR, were derived from scales proposed by academians [Jaworski and Kohli, 1993, Narver and Slater's, 1990, and Matsuno, 2000] who in turn carried out exhaustive analysis and detailed evaluations to make sure the constructs measured by the scales were valid. Thus the scales used were considered to have content validity.

Criterion: Criterion related validity was evaluated, according to Deng and Dart's 1994 methodology, by examining the multiple correlation coefficient "R" between the different components of market orientation (moigmean = intelligence generation component, moremean $=$ responsiveness component, moidmean $=$ intelligence dissemination component) vs. the measure of performance (perfmean). The resulting multiple correlation coefficient $(R)$ was 0.238 (see Table 31). This value is considerably lower than the value stated by Deng and Dart's [1994] $(R=0.79)$.

This difference can be explained by the fact that the method used in this study is not identical to the method used by Deng and Dart [1994] in several respects. First of all, Deng and Dart [1994] used a scale derived from Narver and Slater's MKTOR scale [1990] that consists of four different components of market orientation (customer orientation, competitor orientation, interfunctional 
coordination and profit emphasis) vs. Jaworski and Kohli's three components (intelligence generation, intelligence dissemination and responsiveness). While the first three components of the MKTOR scale can be related to the first two components of Jaworski and Kohli's scale [1993] used here [Diamantopoulus and Hart, 1993], the final dimensions on each are not equivalent. The fourth component of the Narver and Slater scale [1990] (profit emphasis) may strongly affect the businesses performance measure association accounting for the higher $\mathbf{R}$.

Second, their single item performance relative to company objectives measure is quite different from the one used in this study. Deng and Dart's [1994] is based on eleven different performance measurements ${ }^{13}$, vs. the four performance measurements used in this study (performance relative to company objectives, relative to major competitors, sales growth, and market share growth). Additionally, Deng and Dart [1994] argue that criterion related validity...

"...is concerned with the extent to which the score on the instrument is related to an independent measure of the relative criterion. For example, a test designed to predict future success in college would be said to have high criterionrelated validity if its scores were highly correlated with actual performance as measured, say, by grade point average.

\footnotetext{
${ }^{13}$ Overall financial performance, corporate liquidity, sales volume, market share, penetration of US market, sales in other export markets, new product development, developing new markets, quality improvements, productivity, relative to expectation.
} 
Criterion-related validity of the four measures of market orientation would be demonstrated if the scores on the measures are highly and positively correlated with actual performance. In other words, these measures, taken together, should be able to serve as a predictor of actual marketing success".(p.736)

This is not necessarily true. The first model proposed in this research is actually designed to test for this relationship, so using this association as a validity test of the construct would not be appropriate. In this model (also used by Deng and Dart [1994]), and all other models to be tested in this study, performance is related to market orientation, not equivalent to it. Second, marketing success, as quoted in the second paragraph above, is not equivalent to business performance, it is only associated with it. Indeed, as noted in the literature review, the association between market orientation and performance has not always been found to be high or even significant.

Thus the multiple regression of the components of market orientation vs. performance is not a valid test of criterion validity. A more fitting test would be a correlation between MKTOR scale and the MARKOR scale, since they are both "independent measures" of the same relative criterion. Another fitting test would be to correlate the market orientation measure against some other independent measure of the market orientation of the business such as customer evaluations of the firm on market orientation. Alternatively, the tests carried out to measure 
construct validity, described below, proved to be a more appropriate assessment of criterion validity as well as construct validity.

Construct: According to Deng and Dart [1994], "a measure can be said to have construct validity if it measures the theoretical construct or trait that it was designed to measure". This can be tested by examining both discriminant and convergent validity. To assess both types of validity, the market orientation measure (momean) was compared using a Pearson correlation [Harris, 2001] against the set of descriptions of business philosophies used by Harris [2001], and Deng and Dart [1994]:

- Production orientation

The key to business success is producing quality goods and services at a reasonable cost. Good products and services sell themselves. If possible, products and services should be standardized to keep costs down.

- Sales Orientation

The key to business success lies in persuading potential customers to buy your goods and services through advertising, personal selling or other means. Potential customers must be informed and convinced of the benefits of the products. 
- Market Orientation

The key to business success is to integrate all company activities and personnel towards satisfying customers, while providing satisfactory profits to the firm. The firm should find out what benefits customers want and then provide these benefits through goods and services.

The results showed a significant $(R=0.30, \alpha=0.00)$ correlation between "momean" and the market orientation philosophy (philq3). Moreover, the results showed no significant correlation between "momean" and the production $(R=$ $0.15, \alpha=0.06)$ or sales orientation $(R=0.10, \alpha=0.20)$ philosophies (philq1, philq2) (see Table 32). This indicates both discriminant and convergent validity for the market orientation scale (and is a more appropriate assessment of criterion validity).

Additionally, to make sure the environmental variables are discrete the market variables (mkmtmean, mkcpmean, mkttmean, mkdmmean) were correlated against each other. The resulting coefficients were less than the Cronbach's alpha coefficients of each individual variable, meaning the market variables are indeed discrete and not related to each other [Harris 2001]. 


\subsection{Marke orientation, the environment and performance}

\subsubsection{Market orientation vs. Performance: model}

Initially, this research used multiple regression between market orientation and each performance variable in order to find a potential impact of market orientation on the business performance of the company as shown in model 1 (please refer model 1 in Figure 3 and Table 6). A set of four equations was built; each containing one performance variable as dependent variable and market orientation as the independent variable.

$Y=b_{0}+b_{1} x$

Were $Y$ is a performance variable, and $X$ is market orientation (momean)

The results are summarized Table 15 (see Appendix 1.5 for the full set of results).

The results are all significant at the 0.05 level, and they support hypothesis 1. It is important to note that the adjusted $R$ square values obtained throughout reported range between 0.02 (see Table 15) and 0.32 (see Table 57 ). In comparison, Greenley [1995] reported adjusted $R$ square values of 0.09 to 0.12 throughout their study, and Harris [2001] of 0.13 to 0.21 . 
Table 15. Model 1 results

\begin{tabular}{|l|c|c|c|c|}
\hline Performance variable & $R$ & Adj $R$ square & $F$ & Sig \\
\hline performance relative to company objectives & 0.183 & 0.027 & 5.22 & 0.024 \\
\hline performance relative to competitors & 0.170 & 0.022 & 4.44 & 0.037 \\
\hline sales growth & 0.181 & 0.026 & 5.07 & 0.026 \\
\hline market share growth & 0.230 & 0.047 & 8.40 & 0.004 \\
\hline
\end{tabular}

The positive results of model 1 of this study are in line with the results of most of the authors studied in this research. Although, it contrasts with the results of Jaworski and Kohli [1993] who did not find a significant link between market orientation and market share growth; Diamantopoulos \& Hart [1993] who found no significant link between market orientation and performance; Noble et al [2002], who found only a weak relationship between performance and one of the dimensions of Market Orientation; and Harris [2001] and Greenley [1995] who found only a significant relationship between market orientation and performance when the link was moderated by environmental variables.

5.4.2 Performance vs. market orientation and environmental variables: model 2

To test model 2 the research used multiple regression between market orientation and all environmental variables against each performance variable in 
order to find a potential impact of all variables on the business performance of the company [Harris 2001, Jaworski and Kohli, 1993, Kumar et al 1998, Narver and Slater 1990], (see model 2 in Figure 3 and Table 6). A set of four equations was built; each containing one performance variable as the dependent variable and both market orientation and the environmental variables as independent variables.

The results for each performance variable are described below:

\section{Performance relative to company objectives:}

The results of model 2 using performance relative to company objectives as the dependent variable show market orientation as significant and positive. This means that the higher the market orientation of the company, the better its performance relative to company objectives. These results support hypothesis 1.

Additionally, the results show competitive intensity as significant and negative. This means that the lower the competitive intensity experienced by the company the better its performance relative to company objectives. These results suppont hypothesis 3b. Finally, the results show overall market demand as significant and positive. This means that the higher the overall market demand experienced by the company the better its periormance relative to company objectives. These results support hypothesis 3a. Both inferences are straight foward and reasonable. 
Table 16. Model 2 for Performance relative to company objectives

\begin{tabular}{|c|c|c|c|c|}
\hline & & $\begin{array}{c}\text { Standardized } \\
\text { Coefficients } \\
\text { Beta }\end{array}$ & 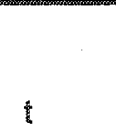 & Sig. \\
\hline \multirow[t]{6}{*}{1} & (Constant) & & 5.220 & .000 \\
\hline & MOMEAN & .167 & 2.172 & .031 \\
\hline & MKMTMEAN & -.073 & -.830 & .408 \\
\hline & MKCPMEAN & -.167 & -2.074 & .040 \\
\hline & MKTTMEAN & -.050 & -.544 & .587 \\
\hline & MKDMMEAN & .273 & 3.249 & .001 \\
\hline
\end{tabular}

a. Dependent Variable: overall performance

$\operatorname{adj} R$ Square $=0.132, F=5.586, a<0.00$

\section{Performance relative to major competitors:}

The results using performance relative to competitors as the dependent variable show the same relationships as the results of performance relative to company objectives, supporting hypothesis 1 , hypothesis $3 a$ and $3 \mathrm{~b}$ :

1. A market orientation is associated with better performance for the company.

2. The lower the competitive intensity experienced by the company, the higher its performance.

3. The higher the overall market demand experienced by the company, the better its performance against the competition. Since high demand was 
measured across the entire market, it affects all companies equally. Thus, given all other things being equal, high overall market demand is not sufficient to guarantee a single company will excel over its competitors. This is an initial indication that a moderator effect may be hidden somewhere in the relationship between overall market demand and performance.

Table 17. Model 2 for performance relative to competitors

\begin{tabular}{|c|c|c|c|c|}
\hline \multirow{2}{*}{\multicolumn{2}{|c|}{ Model }} & $\begin{array}{l}\text { Standardized } \\
\text { Coefficients }\end{array}$ & \multirow[b]{2}{*}{$\mathfrak{t}$} & \multirow[b]{2}{*}{ Sig. } \\
\hline & & \multirow[t]{2}{*}{ Beta } & & \\
\hline 1 & (Constant) & & 8.212 & .000 \\
\hline & MOMEAN & .161 & 2.087 & .039 \\
\hline & MKMTMEAN & -.081 & -.919 & .360 \\
\hline & MKCPMEAN & -.221 & -2.737 & .007 \\
\hline & MKTTMEAN & -.059 & -.636 & .526 \\
\hline & MKDMMEAN & .214 & 2.531 & .012 \\
\hline
\end{tabular}

a. Dependent Variable: Performance relative to competition

adj $R$ Square $=0.127, F=5.413, \alpha<0.00$

Sales growth:

With sales growth as the dependent variable the only two significant positive relationships reported are market orientation and overall market demand. Once again, both inferences are straight forward and reasonable. These results support hypothesis 1 and hypothesis $3 a$. 
Table 18. Model 2 for sales growth

\begin{tabular}{|c|c|c|c|c|}
\hline \multirow{2}{*}{\multicolumn{2}{|c|}{ Model }} & $\begin{array}{l}\text { Standardized } \\
\text { Coefficients }\end{array}$ & \multirow[b]{2}{*}{$t$} & \multirow[b]{2}{*}{ Sig. } \\
\hline & & Beta & & \\
\hline \multirow[t]{6}{*}{1} & (Constant) & & 4.136 & .000 \\
\hline & MOMEAN & .153 & 2.106 & .037 \\
\hline & MKMTMEAN & -.122 & -1.481 & .141 \\
\hline & MKCPMEAN & -.074 & -.969 & .334 \\
\hline & MKTTMEAN & -.091 & -1.050 & .295 \\
\hline & MKDMMEAN & .453 & 5.711 & .000 \\
\hline
\end{tabular}

a. Dependent Variable: sales growth

$\operatorname{adj} R$ Square $=0.230, F=10.018, a<0.00$

\section{Market share growth}

In the case of market share growth as dependent variable, the results show a positive, significant relationship between market orientation and market share growth. These results support hypothesis 1 . The results also show a very significant positive relationship between overall market demand and market share growth. Its interpretation is not straight forward given that the variable implies equal high demand for both the respondent's company as well as the competition. Thus once again, given all other things being equal, high overall market demand is not sufficient to provide a single company the condition to grow its market share compared to its competitors. This is another indication that 
a moderator effect may be hidden somewhere in the relationship between overall market demand and performance.

Table 19. Model 2 for market share growth

\begin{tabular}{|c|c|c|c|c|}
\hline \multirow{2}{*}{\multicolumn{2}{|c|}{ Model }} & $\begin{array}{l}\text { Standardized } \\
\text { Coefficients }\end{array}$ & \multirow[b]{2}{*}{ 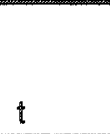 } & \multirow[b]{2}{*}{ Sig. } \\
\hline & & Beta & & \\
\hline & (Constant) & & 4.595 & .000 \\
\hline & MOMEAN & .203 & 2.768 & .006 \\
\hline & MKMTMEAN & -.145 & -1.744 & .083 \\
\hline & MKCPMEAN & -.141 & -1.843 & .067 \\
\hline & MKTTMEAN & -.030 & -.337 & .737 \\
\hline & MKDMMEAN & & 4.459 & .000 \\
\hline
\end{tabular}

a. Dependent Variable: market share growth

adj $R$ Square $=0.214, F=9.208, \alpha<0.00$

\section{4 .3 Comparing model 1 vs model 2}

Comparing the adj $R$ square of model $1 \mathrm{vs}$. model 2 shows that the model that includes the market variables (model 2 ) is relatively better in predicting the dependent variables of performance than the model that only contains the market orientation variable as dependent variable. This is not unexpected since we find from the resuls that, besides market orientation, both overall market demand and competitive intensity have some effect on a company's performance as well. 


\subsubsection{Mutiplicative interaction terms}

Moderating effects of the environmental variables on the market orientation-performance link were studied by using moderated regression analysis [Harris, 2001, Greenley 1995]. This procedure involves the introduction of multiplicative interaction terms into the regression equations mentioned previously:

$$
Y=b_{0}+b_{1} X_{1}+b_{2} X_{2}+b_{3} X_{1} X_{2}+\ldots+b_{n} X_{n}+e
$$

Where $X_{1}$ is market orientation, $X_{2}$ is the environmental factor (moderator variable), $X_{1} X_{2}$ is the multiplicative interaction term and $b_{3}$ is the interaction term [Harris 2001]. A moderator effect is indicated when all interaction terms $\left(b_{3}, X_{1}\right.$ and $X_{2}$ ) are statistically significant. If this is the case, the derivative of equation 1 will provide evidence of the form of the relationship between market orientation and performance, over the range of the moderator variable [Harris, 2001, Greenley 1995]. The derivative of equation 1 is:

$$
d Y / d X_{1}=b_{1}+b_{3} X_{2}=0
$$

Solving for $X_{2}$ will provide the inflection point in the moderating effect. 
The multiplicative interaction terms were calculated by multiplying market orientation (momean) by the environmental variable studied:

$$
\begin{aligned}
\text { momkmt } & =\text { momean } * \text { mkmtmean } \\
\text { momkcp } & =\text { momean *mkcpmean } \\
\text { momktt } & =\text { momean } * \text { mkttmean } \\
\text { momkdm } & =\text { momean } * \text { mkdmmean }
\end{aligned}
$$

\section{Moderating effect of market turbulence}

Market turbulence was found to have no moderation effect in the link between market orientation and any of the performance measures studied. Refer to Appendix 1.6.1.

\section{Moderating effect of competitive intensity}

Periomance relative to company objectives: The multiplicative interaction term MOMKCP was found to be significant ( 0.05 level), as well as the competitive intensity variable (mkcpmean) on its own. Market orientation (momean) was found to be close to significance at the 0.05 level (sig $=0.087$ ), so it is considered to be significant. Since all three variables required to report a moderating effect were significant [Harris, 2001, Greenley 1995], it is concluded 
that competitive intensity has a moderating effect over the link between market orientation and performance relative to company objectives (perfq1).

Table 20. Competitive intensity mutiplicative interaction term against performance relative to company objectives

\begin{tabular}{|c|c|c|c|c|c|c|}
\hline \multirow{2}{*}{\multicolumn{2}{|c|}{ Model }} & \multicolumn{2}{|c|}{$\begin{array}{l}\text { Unstandardized } \\
\text { Coefficients }\end{array}$} & \multirow{2}{*}{$\begin{array}{c}\begin{array}{l}\text { Standardized } \\
\text { Coefficients }\end{array} \\
\text { Beta }\end{array}$} & \multirow[b]{2}{*}{$t$} & \multirow[b]{2}{*}{ Sig. } \\
\hline & & $B$ & Std. Error & & & \\
\hline \multirow[t]{7}{*}{1} & (Constant) & 7.045 & 1.784 & & 3.948 & .000 \\
\hline & MOMEAN & -.779 & .452 & -.528 & -1.724 & .087 \\
\hline & MKMTMEAN & $-9.96 E-02$ & .100 & -.086 & -.993 & .322 \\
\hline & MKCPMEAN & -1.460 & .545 & -1.194 & -2.681 & .008 \\
\hline & MKTTMEAN & $-2.99 E-02$ & .082 & -.033 & -.364 & .716 \\
\hline & MKDMMEAN & .232 & .078 & .250 & 2.994 & .003 \\
\hline & MOMKCP & .331 & .141 & 1.256 & 2.343 & .021 \\
\hline
\end{tabular}

a. Dependent Variable: performance relative to objectives, perfq1

Adjusted $R$ square $=0.158, F=5.713, a<0.00$

The derivative of the regression equation was calculated as:

$\delta$ perfq $1 / \delta$ momean $=-0.779+0.331 *$ mkcpmean $=0$

Solving for mkcpmean:

mkcpmean $=0.779 / 0.331=2.353$ 
The above value is the inflection point of mkcpmean (competitive intensity). When substituting values greater than 2.353 (such as 3 ) on the derivative equation, it results in positive values. Values lower than 2.353 (such as 2), give negative values. This means that for high values of competitive intensity the relationship between Market Orientation and Performance relative to company objectives is positive and for lower values, the relationship is negative. This supports Hypothesis 2c.

Only $20.4 \%$ of all respondent companies reported competitive intensity values lower than the inflection point (2.353), and $79.6 \%$ reported values above the inflection point. This suggests that the relationship between market orientation and performance relative to company objectives is positive for most companies. This supports Hypothesis 1.

Sales growth: The multiplicative interaction term MOMKCP was found to be significant ( 0.05 level), as well as the competitive intensity variable (mkcpmean) on its own. Market orientation (momean) was not found to be close to significance at the 0.05 level ( $\mathrm{sig}=0.108$ ), so it is not considered to be significant. Harris [2001] and Greenley [1995] suggest that the momean, MOMKCP and MKCPMEAN must all be significant to find a moderating effect. Since all three variables required to report a moderating effect were not significant, it is concluded that competitive intensity has no moderating effect over the link between market orientation and sales growth (perfq3). 
Competitive intensity showed to have no moderation effect in the link between market orientation and performance relative to competition or market share growth. Refer to Appendix 1.6.2.

\section{Moderating effect of technological turbulence}

Technological turbulence showed to have no moderation effect in the link between market orientation and any of the performance measures studied. Refer to Appendix 1.6.3.

Moderating effect of overall market demand

Performance against the competition: The multiplicative interaction term MOMKDM was found to be significant, as well as the overall market demand variable (mkdmmean) and market orientation (momean). Since all three variables required to report a moderating effect were significant, it is concluded that overall market demand has a moderating effect over the link between market orientation and performance against the competition (perfq2). 
Table 21. Domand interaction term vs. performance against the competition

\begin{tabular}{|c|c|c|c|c|c|c|}
\hline \multirow[b]{2}{*}{ Mod } & & \multicolumn{2}{|c|}{$\begin{array}{l}\text { Unstandardized } \\
\text { Coefficients }\end{array}$} & \multirow{2}{*}{$\begin{array}{l}\begin{array}{c}\text { Standardized } \\
\text { Coefficients }\end{array} \\
\text { Beta }\end{array}$} & \multirow[b]{2}{*}{$t$} & \multirow[b]{2}{*}{ Sig. } \\
\hline & & $\mathrm{B}$ & Std. Error & & & \\
\hline \multirow[t]{7}{*}{1} & (Constant) & 1.644 & 1.026 & & 1.603 & .111 \\
\hline & MOMEAN & .776 & .257 & .663 & 3.022 & .003 \\
\hline & MKMTMEAN & $-7.37 E-02$ & .080 & -.080 & -.927 & .355 \\
\hline & MKCPMEAN & -.200 & .077 & -.206 & -2.578 & .011 \\
\hline & MKTTMEAN & $-4.82 E-02$ & .065 & -.067 & -.740 & .460 \\
\hline & MKDMMEAN & .858 & .294 & 1.164 & 2.921 & .004 \\
\hline & MOMKDM & -.186 & .076 & -1.124 & -2.439 & .016 \\
\hline
\end{tabular}

a. Dependent Variable: performance against the competition, perfq2

Adjusted $R$ square $=0.156, F=5.655, \alpha<0.00$

The derivative of the regression equation was calculated as:

$\delta$ perfq2 $/ \delta$ momean $=0.776-0.186 *$ MKDMMEAN $=0$

Solving for mkdmmean:

mkdmmean $=-0.776 /-0.186=4.172$

The above value is the inflection point of mkdmmean coverall market demand). When substituting values greater than 4.172 (such as 5) on the derivative equation, it results in negative values. Values lower than 4.172 (such as 4), give positive values. This means that for high values of overall market demand the relationship between Market Orientation and the performance 
against the competition is negative and for lower values, the relationship is positive. This supports Hypothesis 2 a.

The interpretation is straight forward: if overall market demand is low, it is more important to have a market orientation to realize good performance against the competition.

An overall demand value lower than the inflection point (4.172) was reported by $89.5 \%$ of all respondent companies, and only $10.5 \%$ reported values above the inflection point. Once again, this suggests that the relationship between market orientation and performance against the competition is positive for the vast majority of companies. This supports Hypothesis 1.

Market share growth: The multiplicative interaction term MOMKDM was found to be significant, as well as the overall market demand variable (mkdmmean) and market orientation (momean). Since all three variables required to report a moderating effect were significant, it is concluded that overall market demand has a moderating effect over the link between market orientation and market share growth (periq4). 
Table 22. Demand against market share growth

\begin{tabular}{|c|c|c|c|c|c|c|}
\hline \multirow{2}{*}{\multicolumn{2}{|c|}{ Model }} & \multicolumn{2}{|c|}{$\begin{array}{l}\text { Unstandardized } \\
\text { Coefficients }\end{array}$} & \multirow{2}{*}{$\begin{array}{l}\begin{array}{l}\text { Standardized } \\
\text { Coefficients }\end{array} \\
\text { Beta }\end{array}$} & \multirow[b]{2}{*}{$t$} & \multirow[b]{2}{*}{ Sig. } \\
\hline & & $B$ & Std. Error & & & \\
\hline \multirow[t]{7}{*}{1} & (Constant) & .154 & 1.259 & & .122 & .903 \\
\hline & MOMEAN & .964 & .315 & .639 & 3.059 & .003 \\
\hline & MKMTMEAN & -.172 & .098 & -.145 & -1.761 & .080 \\
\hline & MKCPMEAN & -.160 & .095 & -.128 & -1.683 & .095 \\
\hline & MKTTMEAN & $-3.41 E-02$ & .080 & -.037 & -.427 & .670 \\
\hline & MKDMMEAN & 1.125 & .361 & 1.183 & 3.118 & .002 \\
\hline & MOMKDM & -.208 & .094 & -.977 & -2.225 & .028 \\
\hline
\end{tabular}

a. Dependent Variable: market share growth, perfq4

Adjusted $R$ square $=0.265, F=8.707, \alpha<0.00$

The derivative of the regression equation was calculated as:

$\delta$ perfq $4 / \delta$ momean $=0.964-0.208 *$ MKDMMEAN $=0$

Solving for mkdmmean:

mkdmmean $=-0.964 /-0.208=4.635$

The above value is the inflection point of mkdmmean (overall market demand). When substituting values greater than 4.635 (such as 5) on the derivative equation, it results in negative values. Values lower than 4.635 (such as 4), give positive values. This means that for high values of overall market demand the relationship between Market Orientation and market share growth is 
negative and for lower values, the relationship is positive. This supports Hypothesis $2 a$ as well.

The interpretation is straight forward: if overall market demand is low, it is more important to have a market orientation for one to increase its market share against the competition.

An overall demand value lower than the inflection point (4.635) was reported by $96.7 \%$ of all respondent companies, and only $3.3 \%$ reported values above the inflection point. Once again, this suggests that the relationship between market orientation and performance against the competition is positive for the vast majority of companies. This supports Hypothesis 1.

Overall market demand showed to have no moderation effect in the link between market orientation and performance relative to company objectives or sales growth. Refer to Appendix 1.6.4.

\subsection{Comparing the celecommunications industry to other manufacturing} industries

To tes: Hypotheses $H 4$ and $H 5$, all the environmental variables, the market orientation variable and all other variables from the telecommunications industry (telecommunication group) were compared against those of the rest of the manufacturing industries of Canada (manufacturing group). This was done 
using $t$ tests, and by developing and comparing regression equations for each industry (telecommunication group vs. manufacturing group).

\section{5 .1 t-tests}

To compare the telecommunication group and the manufacturing group, $t-$ tests were carried out on all the scalar variables included in the questionnaires. The only significant results are listed in Table 23.

The complete set of t-tests between the telecommunications group and the manufacturing group are listed in Table 54 in Appendix I.7.

Table 23. Significant t-tests between manufacturing and telecommunication groups

\begin{tabular}{|c|c|c|c|c|c|c|c|}
\hline & $\begin{array}{l}\text { Telecommunication or } \\
\text { manufacturing }\end{array}$ & $\mathbf{N}$ & Mean & $\sigma$ & t & df & Sig \\
\hline \multirow[t]{2}{*}{ MKTTMEAN } & manufacturing & 77 & 3.37 & 1.08 & -2.365 & 150 & 0.019 \\
\hline & telecommunication & 75 & 3.76 & 0.98 & & & \\
\hline \multirow{2}{*}{ MKDMMEAN } & manufacturing & 77 & 2.64 & 0.91 & -2.617 & 150 & 0.010 \\
\hline & relecommunication & 75 & 3.06 & 1.08 & & & \\
\hline
\end{tabular}

Technological turbulence

As expected companies in the telecommunications industry had significantly more technological turbulence than manufacturing industry companies. In other words, telecommunications companies are more prone to 
technological development and high tech characteristics when compared to the more broadly encompassing manufacturing industry. This supports Hypothesis $4 c$.

\section{Market demand}

The results suggest that the telecommunications industry is not experiencing low demand. This is contrary to hypothesis $4 a$, in which we suggested that the telecommunications industry may be currently experiencing low demand.

To further understand the difference between demand for the telecommunications industry and the manufacturing industry, $t$-tests between the telecommunications and manufacturing groups were carried out for each of the two items of the demand variable. The first item measures growth, while the second item measures demand relative to supply, in other words, excess capacity. The results are shown in Table 24.

Table 24. Per item t-test between telecommunications and manufacturing companies for the demand variable

\begin{tabular}{|l|l|l|c|c|c|c|}
\hline & Item & & t & Sig. & mean & $\begin{array}{c}\text { std. } \\
\text { dev. }\end{array}$ \\
\hline \multirow{2}{*}{1} & $\begin{array}{l}\text { Currently our market is } \\
\text { experiencing high growth. }\end{array}$ & Telecom & \multirow{2}{*}{1.606} & 0.110 & 3.05 & 1.272 \\
\cline { 2 - 3 } & Manufacturing & & 2.74 & 1.129 \\
\hline \multirow{2}{*}{2} & $\begin{array}{l}\text { Currently, in our market, } \\
\text { supply exceeds demand. }\end{array}$ & Telecom & - & 0.006 & 2.93 & 1.288 \\
\cline { 6 - 7 } & & Manufacturing & 2.784 & & 3.47 & 1.071 \\
\hline
\end{tabular}


The results of the individual scale item t-tests show that the second item is the large source of the significant difference in demand between telecommunications and manufacturing companies. This suggests that this difference is not solely an issue of recent growth of the telecommunications industry, but more importantly, demand relative to supply.

The t-tests also showed that the telecommunications industry is not experiencing higher competitive intensity than the rest of the manufacturing industry as proposed by Hypothesis $4 \mathrm{~b}$. Additionally, the results also showed that the telecommunications industry has a market orientation just as high as the rest of the manufacturing industry. This does not support hypothesis 5 .

\subsubsection{Comparing regressions of telecommunication and manufacturing groups}

Regression equations were developed based on models 1,2 and 3 using either telecommunication group responses or manufacturing group responses to find any significant differences in the results (see Appendix 1.8). For simplicity reasons the dependent variable used for all regression equations using either telecommunication group responses or manufacturing group responses was the single item overall impression of performance, perfmean. 
Model 1:Pertomance vs. MO

The results show that the relationship between market orientation and performance is significant both for manufacturing and telecommunications companies. The adjusted $\mathrm{R}$ square value indicates that this relationship has approximately the same intensity for both groups.

Table 25. Model 1, manufacturing vs telecommunication

\begin{tabular}{|l|l|l|l|l|}
\hline & $\mathbf{R}$ & Adj R Square & Beta of MOMEAN & Sig \\
\hline Telecommunication & 0.231 & 0.040 & 0.259 & 0.046 \\
\hline Manufacturing & 0.233 & 0.042 & 0.295 & 0.042 \\
\hline
\end{tabular}

Model 2: Performance vs. MO and the environmental variables

The results show a significant relationship between market orientation and performance for the telecommunications industry. For the manufacturing industry, the alpha approaches significance.

Regarding the environmental variables, competitive intensity negatively affects the performance of manufacturing industry companies, but is not significant for telecommunications industy companies. Market turbulence 
approaches significance for the telecommunication group with a negative beta, but is not a significant factor for the manufacturing group.

Table 26. Model 2, manufacturing vs. telecommunication

\begin{tabular}{|l|c|c|}
\hline & $\begin{array}{l}\text { Telecommunication }- \text { Beta } \\
\text { (Sig.) }\end{array}$ & $\begin{array}{l}\text { Manufacturing } \\
\text { (Sig.) }\end{array}$ \\
\hline$R$ & 0.605 & 0.498 \\
\hline Adj R square & 0.320 & 0.195 \\
\hline F & $7.961(0.000)$ & $4.687(0.001)$ \\
\hline MOMEAN & $0.250(0.024)$ & $0.263(0.063)$ \\
\hline MKMTMEAN & $-0.179(0.073)$ & $-0.049(0.685)$ \\
\hline MKCPMEAN & $-0.129(0.205)$ & $-0.262(0.026)$ \\
\hline MKTTMEAN & $-0.069(0.407)$ & $-0.009(0.921)$ \\
\hline MKDMMEAN & $0.348(0.000)$ & $0.254(0.015)$ \\
\hline
\end{tabular}

The results also showed that performance of both manufacturing and telecommunications industry companies are positively affected by overall market demand. The inference is straight forward and reasonable. 
Model 3: Multiplicative interaction terms

Regression equations were developed using moderated regression analysis as per the method used in section 5.4.4, using either manufacturing group responses or telecommunication group responses separately, and the single item overall impression of performance, perfmean, as dependent variable.

The only two results that showed significant moderating effects on the market-orientation link were competitive intensity for manufacturing industry companies, and overall market demand for manufacturing industry companies (see Table 27 and Table 28). The telecommunications industry didn't show any significant moderating effects on the market-orientation link from environmental variables.

These findings initially suggest that model 3 is only representative of the market orientation - performance link of the manufacturing group and not so for the telecommunication group. This will be discussed in section 6 . 
Table 27. Model 3, Regression with demand multiplicative term for manufacturing companies only

Coefficients,

\begin{tabular}{|c|c|c|c|c|c|c|}
\hline \multirow{2}{*}{\multicolumn{2}{|c|}{ Model }} & \multicolumn{2}{|c|}{$\begin{array}{l}\text { Unstandardized } \\
\text { Coefficients }\end{array}$} & \multirow{2}{*}{$\begin{array}{c}\begin{array}{c}\text { Standardized } \\
\text { Coefficients }\end{array} \\
\text { Beta } \\
\end{array}$} & \multirow[b]{2}{*}{$\hat{t}$} & \multirow[b]{2}{*}{ Sig. } \\
\hline & & B & Std. Error & & & \\
\hline \multirow[t]{7}{*}{1} & (Constant) & .213 & 1.584 & & .135 & .893 \\
\hline & MOMEAN & 1.014 & .403 & .799 & 2.519 & .014 \\
\hline & MKMTMEAN & $-9.67 E-02$ & .122 & -.099 & -.795 & .429 \\
\hline & MKCPMEAN & -.190 & .119 & -.192 & -1.598 & .115 \\
\hline & MKTTMEAN & $-2.80 E-02$ & .096 & -.038 & -.292 & .771 \\
\hline & MKDMMEAN & 1.292 & .533 & 1.470 & 2.426 & .018 \\
\hline & MOMKDM & -.272 & .137 & -1.410 & -1.983 & .051 \\
\hline
\end{tabular}

a. Dependent Variable: PERFMEAN

b. Selecting only cases for which Telecom or manufacturing = manufacturing

$\operatorname{adj} R$ Square $=0.227, F=4.723, \alpha<0.00$

Table 28. Model 3, Regression with competitive intensity multiplicative term for manufacturing companies only

Coefficients, ${ }^{\mathrm{a}, \mathrm{b}}$

\begin{tabular}{|c|c|c|c|c|c|c|}
\hline \multirow[b]{2}{*}{ Mod } & & \multicolumn{2}{|c|}{$\begin{array}{l}\text { Unstandardized } \\
\text { Coefficients }\end{array}$} & \multirow{2}{*}{$\begin{array}{c}\begin{array}{c}\text { Standardized } \\
\text { Coefficients }\end{array} \\
\text { Beta }\end{array}$} & \multirow[b]{2}{*}{ t } & \multirow[b]{2}{*}{ Sig. } \\
\hline & & B & Std. Error & & & \\
\hline & (Constant) & 8.287 & 2.316 & & 3.578 & .001 \\
\hline & MOMEAN & -1.028 & .567 & -.810 & -1.814 & .074 \\
\hline & MKMTMEAN & $-9.66 E-02$ & .120 & -.099 & -.807 & .422 \\
\hline & MKCPMEAN & -1.789 & .661 & -1.807 & -2.708 & .008 \\
\hline & MKTTMEAN & $-3.86 E-03$ & .094 & -.005 & -.041 & .968 \\
\hline & MKDMMEAN & .194 & .102 & .220 & 1.904 & .061 \\
\hline & MOMKCP & 398 & .170 & 1.951 & 2.345 & .022 \\
\hline
\end{tabular}

a. Dependent Variable: PERFMEAN

b. Selecting only cases for which Telecom or manufacturing = manufacturing

$\operatorname{adj} R$ Square $=0.243, F=5.070, \alpha<0.00$ 


\subsection{Open ended question results}

Of the 152 responses obtained in this study, 45 respondents provided responses to the open ended question at the end of the survey. Two respondents from the telecommunications group commented on the downturn affecting the telecommunications industry in the last few years. Although one of the respondents mentioned that the industry is currently "on a major rebound and improvement for the last six months". He suggested the study be done a year from the date of his responses. This supports the findings in section 5.5.1 regarding high overall demand for the telecommunications industry, and suggests that a longitudinal study or periodic tracking of the environmental variables may be important to completely understand the business environment of the telecommunications industry.

In total, twelve respondents commented on the high competitive intensity affecting their industry. Nine of those twelve respondents were from the manufacturing group and quoted Asian markets as the highest source of competition. Seven manufacturing industry respondents also mentioned low price as being the only way to compete in their market, although seven other respondents suggested high product quality as the key differentiator. A few other responses referred to a variety of factors affecting their industry: (number of occurrences are in brackets): currency fluctuations (4), shrinking markets (3), high costs of raw material (3), post 9/11 era (2) and low availability of skilled 
labor (2). If deemed appropriate, some of these factors can be used as environmental variables for some industry sectors in future research. 


\section{SUMMARY OF RESULTS AND DISCUSSION}

In general, it was found that the responding companies where highly representative of small, medium and large manufacturing companies of Canada and the findings can be interpreted as reflective of the conditions affecting small, medium and large Canadian companies. On the other hand, the results are not representative of micro companies of Canada, i.e. companies with less than 10 employees and less than a million dollars in sales.

\subsection{Objective 1}

The first objective of this study was to obtain further empirical evidence supporting a link between a market orientation and business performance. Throughout the study the results showed that a market orientation is related to business performance for all three models and for all manufacturing industries, including the telecommunications industry. This supports hypothesis 1 proposed by this research and therefore the first objective of this study.

\subsection{Objective 2}

The second objective of this study was to understand and measure the influence of the environmental factors on the market orientation - business 
performance link. Models 1,2 and 3, and hypothesis 2 (a to d) and 3 (a to d) were proposed to meet the second objective.

\section{Model 1 - Direct relationship of market orientation on performance}

The results for model 1 showed a significant positive relationship between the market orientation of a company and its business performance.

This suggests that a market orientation helps a company do well in all performance aspects measured. In other words, businesses with a market orientation are more likely to have higher performance than competitors, higher sales, greater increases in market share, and higher performance relative to organizational goals. This is true both for manufacturing companies and telecommunication companies. This is in line with the results of most of the authors studied in this research, but contrasts with the results of the studies of Jaworski and Kohli [1993], Diamantopoulos \& Hart [1993]; Noble et al [2002], Harris [2001] and Greenley [1995] as discussed in section 5.4.1.

Model 2 - Direct Relationship of both market orientation and the environmental variables on performance

The results of the study also showed that high overall market demand and low competitive intensity positively affect a company's performance. This is clear and its interpretation straight forward. The higher the overall market demand the higher the performance of a company will be. And the more intense the 
competition, the more difficult it is to gain high performance. These results supports hypothesis $3 a$ and $3 b$ proposed by this research and provides initial evidence to meet the second objective of this study. This is in partial accordance with Harris [2001], who found a direct effect of competitor intensity on performance, but which also found a direct effect of market turbulence on organizational performance. It is also in contrast with Narver and Slater's 1990 study that found a direct negative relationship between Technological Turbulence and performance.

As previously noted, the two performance variables that showed direct links with overall market demand were performance relative to major competitors and market share growth. As discussed in section 5.4.2, both performance measures imply equal high demand for both the respondent's company as well as the competition. Thus, given all other things being equal, high overall market demand is not sufficient to guarantee a specific company will excel over its competitors. This provided an initial indication that a moderator effect may be hidden somewhere in the relationship between overall market demand and performance, and thus the importance of further exploration of moderating influences of environmental factors (model 3).

The differences between the results of the studies mentioned with the results of this research indicates the importance of further exploration of environmental factors across a range of countries, sectors and market conditions. 
Model 3 - Relationship of market orientation on performance moderated by environmental variables

The results showed that performance is not only affected by market orientation, overall market demand and competitive intensity directly (model 1 and 2), it also showed that studying a moderating effect of environmental variables is important to describe the market orientation - performance relationship correctly. This is evident from the adjusted $R$ square results from each model. These values are discussed later in this section.

The results showed that if overall market demand is low and competition is high, it is very important for a company to choose a market orientation strategy to realize strong performance. This supports hypothesis $2 a$ and $2 c$ proposed by this research and provides further evidence to meet the second objective of this study. On the other hand, it showed that technological turbulence and market turbulence did not impact company performance or the importance of a market orientation to have successful business performance. In other words, even when technology and market demands are changing quickly, businesses that address customer needs through a market orientation strategy approach will be more successful.

It is important to note that the results of moderating effects of the environmental variables on the market orientation - performance link do not coincide exactly with the results of any other study reviewed in this research. It 
partially coincides with Diamantopoulus and Hart's [1993] results that show a moderating effect of demand and competitive intensity on the market orientation - performance link, although Diamantopoulus and Hart's [1993] study also found a moderating effect of market turbulence. This study also partially coincides with Kwaku and Ashok's 1998 study, which found a moderating effect not only for demand but also for technological turbulence, and found no moderating effect for competitive intensity. Finally, it partially coincides with Harris's 2001 study, which found a moderating effect for competitive intensity and market turbulence, but found no moderating effect for demand.

Additionally, the results of this study contrast with the results of Jaworski and Kohli [1993] and Narver and Slater [1994] who found no moderating effect of any environmental variable on the market orientation - performance link, and Greenley [1995], who found a moderating effect between technological turbulence and market turbulence on the market orientation - performance link, but no moderating effect of demand or competitive intensity.

The differences between the results of the mentioned studies with the results of this research suggests once again that the sample population of this study and the environmental variables affecting may differ for different industries and under different times and places, indicating that the study of this particular population is important to better understand the complex nature of the market orientation-performance association. 
As can be seen from Table 29 the adjusted $R$ square values of model 2 are greater than those of model 1 , suggesting that model 2 is a better fit than model 1. On average (see Table 29, "Model 3 average adjusted R square"), the mean of all adjusted $R$ squares for each industry and performance variable was greater for model 3 than the adjusted $R$ squares of model 2. This suggests that, on average, model 3 is a better fit than model 2 .

It can be argued that since the regressions for model 3 for the telecommunications industry, although significant, reported non-significant multiplicative interaction terms and that the adjusted $R$ square for model 2 for telecommunications industry is not only significant, but also high, then model 2 may be a better fit to describe the market orientation - performance link for the telecommunications industry. However, since the environmental variables surrounding the telecommunications industry may be in a temporal state, changes in those conditions could possibly result in a significant multiplicative interaction term for the telecommunications industry in the future. For example, overall market demand in the telecommunications industry is currently higher and competitive intensity lower than the rest of the manufacturing industry, but if demand ever goes down and competitive intensity grows to the levels of the rest of the manufacturing industry (as was initially suggested in this research) the multiplicative interaction terms for model 3 for the telecommunications industry may show significant results. 
Table 29. Adjusted $\mathbf{R}$ square comparisons of all regressions

\begin{tabular}{|c|c|c|c|c|c|c|}
\hline & $\begin{array}{l}\text { Env. } \\
\text { Vars. }\end{array}$ & $\begin{array}{c}\text { Performance } \\
\text { mean }\end{array}$ & Overall & $\begin{array}{l}\text { Performance } \\
\text { relative to } \\
\text { competition }\end{array}$ & $\begin{array}{l}\text { Salas } \\
\text { growth }\end{array}$ & $\begin{array}{l}\text { Market } \\
\text { share } \\
\text { growth }\end{array}$ \\
\hline \multicolumn{7}{|l|}{ Model 1} \\
\hline All respondents & & & 0.027 & 0.022 & 0.026 & 0.047 \\
\hline Telecom & & 0.04 & & & & \\
\hline Manufacturing & & 0.042 & & & & \\
\hline \multicolumn{7}{|l|}{ Model 2} \\
\hline All respondents & & & 0.132 & 0.127 & 0.23 & 0.214 \\
\hline Telecom & & 0.32 & & & & \\
\hline Manufacturing & & 0.195 & & & & \\
\hline \multicolumn{7}{|l|}{ Model 3} \\
\hline \multirow[t]{4}{*}{ All respondents } & MT & & 0.129 & 0.124 & 0.225 & 0.209 \\
\hline & $\mathrm{CP}$ & & 0.158 & 0.14 & 0.25 & 0.22 \\
\hline & $\pi$ & & 0.126 & 0.122 & 0.225 & 0.21 \\
\hline & $\mathrm{DM}$ & & 0.44 & 0.156 & 0.23 & 0.234 \\
\hline \multirow[t]{4}{*}{ Telecom } & MT & 0.319 & & & & \\
\hline & $\mathrm{CP}$ & 0.322 & & & & \\
\hline & $\pi$ & 0.318 & & & & \\
\hline & $\overline{D M}$ & 0.323 & & & & \\
\hline \multirow[t]{4}{*}{ Manufacturing } & MT & 0.184 & & & & \\
\hline & $\mathrm{CP}$ & 0.243 & & & & \\
\hline & $\pi$ & 0.191 & & & & \\
\hline & $\overline{D M}$ & 0.227 & & & & \\
\hline \multicolumn{7}{|c|}{ Model 3 average adjusted $R$ square } \\
\hline All respondents & & & 0.138 & 0.136 & 0.233 & 0.218 \\
\hline Telecom & & 0.321 & & & & \\
\hline Manufacturing & & 0.211 & & & & \\
\hline
\end{tabular}

- Env. Vars. = Environmental Variables, MT = Market hurbulence, CP = Competitive intensity, $D M=$ Demand, $T T=$ Technological Turbulence, telecom = telecommunication group, manufacturing = manufacturing group, all respondents = telecommunication and manufacturing group combined

- Adjusted $R$ square values in bold are significant

On the other hand, since changes in organizational orientation may take several years and are extremely complex and difficult to effect, and given that the 
percentage of companies beyond the moderating influence of environmental variables is relatively low (see section 5.4 .4 ), it may make sense for a company to always focus on obtaining and maintaining a market orientation regardless of the status of the environmental conditions surrounding it.

Finally, it can be seen from Table 29 that the adjusted $R$ square results of sales growth and market share growth regressions are almost twice as high as those of performance relative to company objectives and performance relative to competition regressions. This can be due to sales growth and market share growth being relatively quantitative performance measures, compared to performance relative to company objectives and performance relative to competition which are more qualitative measures of performance. Thus, the difference in adjusted $R$ square results from the kind of "fix" that CEOs can get on the more quantitative measures (sales growth and market share growth). It may give them a better, more concrete reference point for their responses.

\subsection{Objective 3}

\section{Manufacturing vs. telecommunications industry}

Several interesting conclusions were obtained from the results, when comparing the telecommunication and the manufacturing industries. First of all, when compared to the responses from other manufacturing industries, businesses operating in the telecommunications industry in 2004 do not see their 
industry as experiencing low demand. This is contrary to what this research had initially hypothesized and suggests that either the telecommunications industry has recuperated from the hypothesized woes it experienced at the turn of the millennium, or that the industry itself is typically affected by high demand.

The results also showed that a market orientation is just as significant for telecommunications industry companies as for manufacturing industry companies. The performance of the manufacturing industry was directly affected by market demand and competitive intensity, as well. In contrast, the telecommunications industry was only directly affected by market orientation and overall market demand. This can be explained by the fact that the telecom industry experiences significantly more demand and lower competitive intensity than the rest of the manufacturing industry, suggesting that high overall market demand may diminish the effect of competition on the performance of telecommunications companies, i.e. new competing companies in the telecommunications industry may not affect the performance of established telecommunications companies given the high overall market demand experienced by both.

Additionally, the results showed that the environmental variables do not moderate the link between market orientation and performance for companies in the telecommunications industry. In contrast, the link is moderated by overall market demand and competitive intensity for manufacturing companies. This means that a market orientation is even more critical for telecommunications 
companies. Their performance is more dependent on strategy choice and less dependent on variances in the conditions of market, competition, and technology evolution.

\subsection{Objective 4}

Six conclusions and bases for recommendations were obtained from the results of the study:

1. A company will always benefit from a market orientation regardless of industry sector

2. High overall market demand and low competition will help achieve good business performance, but even under these conditions, a market orientation means better performance

3. The importance of maintaining a market orientation becomes even more apparent when overall market demand begins to lag and/or competition begins to increase

4. Industries with both high and low technological turbulence benefit from a market orientation

5. A market orientation benefits companies with customers whose needs and demands are evolving rapidly as well as those with more stable needs 
6. The perfomance of telecommunications industry companies is more dependent on a market orientation and less dependent on conditions of market, competition, and technology evolution than the rest of the manufacturing industry. 


\section{LIMITATIONS}

One of the limitations of this research is that the results are not representative of micro companies of Canada, i.e. companies with less than 10 employees and less than a million dollars in sales. Failure rates of micro companies are high in the first few years after startup compared to small, medium and large companies in $\mathrm{Canada}^{14}$, so it may be critical to redo the study focusing on micro companies to see if these results apply to them as well.

Another key limitation of this research is in the population size. The number of available telecommunications manufacturers of Canada was not large enough to allow for a sample size that would yield a higher number of responses. The power of this research may not be sufficient to provide trustworthy results. Nonetheless, adjusted $R$ squares for all three models were equal or higher than those of other studies reviewed in this research (see section 5.4.1). Additionally, some of the response rates for the studies reviewed for this research where as low as 62 responses [Kwaku and Ashok 1998]. In fact, of the ten studies that yielded results reviewed for this research, five had fewer respondents than those used in this study.

Another shortcoming in the research design is that the study used only one observation, at one point in time. Given that the telecommunications industry and the Canadian economy may still be undergoing market and business changes, some companies may be at different stages of being affected by the

\footnotetext{
${ }^{14}$ http://strategis.ic.gc.ca/epic/internet/insbrp-rppe.nsflen/rd00671e.html
} 
economic downturn and the telecommunications slump, or its recovery. Additionally, the change from a production orientation to a market orientation may take time not accounted for in this type of research [Jaworski and Kohli 1990]. Only Noble et al [2002] carried out a longitudinal study of the market orientation - performance link, and found no clear effect of market orientation on business performance. Changing environmental variables during their longitudinal research could have contributed to the unclear results obtained by their study. Unfortunately, they did not study the effect of environmental variables on the market orientation - performance link.

Another such unaccounted-for lag will be the time between the implementation of a market orientation and an improvement in business performance [Harris 2001].

Finally, leniency errors are a possible problem that can be encountered when using self administered surveys with interval scales. Given that Chief Officers and other top managers were asked to report the behavior of their own companies, they may have tried to hide their own deficiencies by reporting inaccurate or inflated responses. This is argued by Deng and Dart [1994] who note that the MARKOR scale's generic (philosophical) questions may be subject to lip service (i.e. insincere replies). Additionally, given the respondents hefty workload, quick, poorly-thought responses may have provided inaccurate results. 
However, there is no expectation that these issues would differ across respondents and therefore would not affect relationships. Only top level managers could provide the accuracy and overview of the company needed. 


\section{BENEFITS AND IMPLICATIONS}

Just like previous studies, this research provides further empirical evidence of the link between market orientation of a company and its business performance. However, the results of this research differ significantly from those of previous studies. First of all, compared to the studies reviewed which researched the link between market orientation and performance, this study is the only study that uses Farrell and Oczkowski's [1997] proposed market orientation scale. This is significant given that Farrel and Oczkowski's scale [1997] demonstrates several advantages over other comparable scales (please refer to section 4.3). Additionally, it is the only study, besides Deng and Dart's 1994 research that studies a Canadian based sample. The results of both this and Deng and Dart's study [1994] differ significantly from the results of other US and UK based studies (please refer to Table 5 and section 6), especially concerning the moderating effects of the environment. This reaffirms the importance of a study such as this one to understand the particular Canadian business environment. Moreover, there are several differences between Deng and Dart's study [1994] and this one. First of all, Deng and Dart's study finds a significant link between market orientation and performance relative to company objectives, but unlike this study, they do not find a link between market orientation and market share, or market orientation and sales growth. This can be attributed to the fact that Deng and Dart [1994] use the MKTOR scale vs. Farrell and Oczkowski's more robust scale [1997] used in this study. 
Another key benefit of this Canadian-based research, vs. Deng and Dart's 1994 Canadian-based study, is that this research studies the moderating effect of the environmental variables on the market orientation - performance link. The significant moderating effect results obtained from this study not only show that the link between market orientation and performance for manufacturing companies in Canada is moderated by competitive intensity and overall market demand, they also show that the link is not moderated for companies in the telecommunications industry. The difference in these results shows the importance of a study like this that researches both groups separately.

Furthermore, this study provided information regarding the current state of the environment as experienced by the telecommunications industry of Canada. It showed that, contrary to hypothesis $4 a$ proposed by this study, the telecommunications industry may not be experiencing low demand. These results and the rest of the results in section 5 may be useful to other researchers, as well as to those respondents to whom they were sent.

Finally, the questionnaire itself had additional unexpected benefits. First, feedback from one of the pre-test respondents showed that responding to the questionnaire motivated him to question and review his own business practices. This may be true for other respondents of the questionnaire. Second, as stated in section 4.3 , the results obtained from the questionnaire included other scales that may be helpful to other researchers. 


\section{Suggestions for future research}

Further analysis should be done to understand the link between market orientation and business performance between small, medium and large companies to see if the link is just as strong for each type or if environmental conditions affect or moderate the link in any way for each type. Moreover, responses for micro companies (companies with less than 10 employees) and very large companies (over 800 employees) should be obtained to verify if the effects concluded from the results of this study affect micro and very large companies in the same way. Moreover, since very large companies are sometimes comprised of multiple business units that may have different business orientations and different environmental conditions, studying business units as the unit of analysis should be continued as it may also yield important information about market orientation at the SBU area (as has been studied by Narver and Slater [1994] and other authors afterwards).

It is evident from the results of this study that results vary by industry type, country and era, so a study of market orientation, environmental variables and performance for each particular industry is not unreasonable if required.

Furthermore, from the discussion in section 7 and the suggestions of some respondents discussed in section 5.6, a longitudinal analysis of each particular industry or periodic tracking of the environmental variables may be useful to understand the changing environment of a particular industry. 
Finally, as discussed in section 5.6, it may be important for some industries to measure other environmental variables that may affect their industry and the relationship between market orientation and business performance. 


\section{REFERENCES}

Berthon, P. \& Holbrook, M. B. (2000). Beyond market orientation: a conceptualization of market evolution. Joumal of Interactive Marketing, Summer, Vol. 14 Issue 3, 50 - 66

Brownlie, D. T. (1987). The Strategic Management of Technology: a New Wave of Market-led Pragmatism or a Return to Product Orientation? European Journal of Marketing, Vol. 21 Issue 9, 45 - 65

Carson, D. J. (1985). The Evolution of Marketing in Small Firms. European Journal of Marketing. Vol. 19 Issue 5, 7 - 16

Davis, D. (2000), Business research for decision making. USA: Duxbury

Deng, S. \& Dart, J. (1994). Measuring Market Orientation: A Multi-factor, Multiitem Approach. Journal of Marketing Management, Nov94, Vol. 10 Issue 8, 725 742

Diamantopoulos, A. \& Hart, S. (1993). Linking market orientation and company performance: preliminary evidence on Jaworski and kohli's framework. Journal of Strategic Marketing, Vol. 1 Issue 2, 93 - 121

Dillman, D. A. (2000). Mail and internet surveys; the tailored design method. New York: J. Wiley.

Farrell, M. A. \& Oczkowski, E. (1997). An analysis of the MKTOR and MARKOR measures of market orientation: an Australian perspective. Marketing Bulletin, 01136895, Vol. $8,30-41$ 
Gauzente. (1999). Comparing Market Orientation Scales: A Content Analysis, Marketing Bulletin, 01136895, Vol. 10,76-83

Gray, B. \& Matear, S. (1998). Developing a better measure of market orientation. European Joumal of Marketing. Vol. 32 Issue 9/10, 884 - 903

Greenley, G. E. (1995). Market Orientation and Company Performance:

Empirical Evidence From UK Companies. British Journal of Management, Vol. 6 Issue 1, 1- 13

Harris, L. C. (2001). Market orientation and performance: objective and subjective empirical evidence from uk companies. Journal of Management Studies, Vol. 38 Issue 1, $17-43$

Houston, F. S. (1986). The Marketing Concept: What It is and What it is Not. Joumal of Marketing, Vol. 50 Issue 2, 81 - 87

Jaworski, B. J. \& Kohli, A. K. (1990). Market orientation: The construct, research propositions, and managerial implications. Joumal of Marketing, Vol. 54 Issue 2, $1-18$

Jaworski, B. J. \& Kohli, A. K. (1993). Market orientation: Antecedents and consequences. Loumal of Marketing, Vol. 57 Issue 3, $53-70$

Jaworski, B. J., Kohli, A. K., Kumar, A. (1993). MARKOR: A measure of market orientation. Joumal of Marketing Research, Vol. 30 Issue 4, $467-477$ 
Kwaku, A. \& Ashok. R., (1998). Market orientation and performance in the biotechnology. Technology Analysis \& Strategic Management, Vol. 10 Issue 2, $197-210$

Lenain, Patrick \& Paltridge, Sam. (2003) After the telecoms bubble. OECD Observer, Issue 238,13-17

Matsuno, K. (2000). A Refinement and Validation of the MARKOR Scale. Joumal of the Academy of Marketing Science, Vol. 28 Issue 4, 527 - 539

Matsuno, Ken \& Mentzer, John T. (2000) The Effects of Strategy Type on the Market Orientation-Performance Relationship. Journal of Marketing, Vol. 64 Issue 4, p1-16

Maydeu-Olivares, (1998). Market orientation and business economic performance: a mediational model, Business Economics Series 98-59 (09) Working paper, Universidad Carlos III de Madrid. 1 - 41

Morgan, R. E., and Morgan, N. A. (1991) An Exploratory Study of Market Orientation in the U.K. Consulting Engineering Profession. International Journal of Advertising 10, 333-347

Narver, J.C. \& Slater, S.F. (1990). The effect of a market orientation on business profitability. Joumal of Marketing, Vol. 54 Issue 4, 20 - 35

Narver, J C. \& Slater, S. F. (1994). Does competitive environment moderate the market orientation-performance relationship? Journal of Marketing, Vol. 58 Issue $1,46-55$ 
Noble, C. H.; Sinha, R. K.; Kumar, A. (2002). Market Orientation and Alternative Strategic Orientations: A Longitudinal Assessment of Performance Implications. Joumal of Marketing, Vol. 66 Issue 4, 25 - 39

Sevcik, P. (1999). The myth of internet growth, Business Communications Review, Vol. 29, issue 1, 12 - 14

Sharp, B. (1991). Marketing Orientation: More than just customer focus. International Marketing Review, Vol. 8 Issue 4, 20 - 25

Sommers \& Barnes. (2001) Fundamentals of Marketing, $9^{\text {th }}$ Canadian Edition, Toronto, Ontario: McGraw-Hill Ryerson Limited

Steinke, Steve. (2003). Bubble-ology. Network Magazine, Vol. 18 Issue 9, 6

Van Bruggen et al, (2002) Informants in Organizational Marketing Research: Why Use Multiple Informants and How to Aggregate Responses. Journal of Marketing Research, Vol. 39 Issue 4, 469 - 478

Workman Jr. (1993). Marketing's limited role in new product development in one computer systems firm. Journal of Marketing Research, Vol. 30 Issue 4, 405 421 


\section{APPENDICES}

Appendix A: Market Orientation scale comparison 
\# = Question number used to identify the questions in this study

$S=$ Questions used in the survey of this study (in order). Refer to Appendix C.

$\mathrm{A}=$ Farrel and Oczowski [1997] - (used in the analysis of this study)

$B=$ MARKOR32, Jaworski et al [1993]

$C=$ MARKOR20, Jaworski et al [1993]

$\mathrm{D}=\mathrm{MO}$, Matsuno [2000]

$E=M K T O R$, Narver and Slater (not complete ${ }^{15}$ )

$R=$ denotes a reverse coded item.

\section{Table 30. Market orientation scales compared to each other}

\begin{tabular}{|c|c|c|c|c|c|c|c|c|}
\hline & & Question & \multicolumn{6}{|c|}{ Scale } \\
\hline \# & $S$ & Intelligence Generation & $A$ & $B$ & $\mathrm{C}$ & D & $E$ & $R$ \\
\hline 1 & 1 & $\begin{array}{l}\text { Our strategy for competitive advantage is based on our } \\
\text { understanding of customer needs. }\end{array}$ & & & & & $\checkmark$ & \\
\hline 2 & 2 & $\begin{array}{l}\text { Our business strategies are driven by our beliefs about } \\
\text { how we can create greater value for customers. }\end{array}$ & & & & & $\checkmark$ & \\
\hline 3 & 3 & $\begin{array}{l}\text { We target customers and customer groups where we } \\
\text { have, or can develop, a competitive advantage. }\end{array}$ & & & & & $\checkmark$ & \\
\hline 4 & 4 & $\begin{array}{l}\text { We periodically review the likely effect of changes in our } \\
\text { business environment (e.g. regulation) on customers. }\end{array}$ & $\checkmark$ & $\checkmark$ & $\checkmark$ & $\checkmark$ & & \\
\hline 5 & 5 & $\begin{array}{l}\text { In this company, we frequently collect and evaluate } \\
\text { general macroeconomic information (e.g. interest rate, } \\
\text { exchange rate, GDP, industry growth rate, inflation rate). }\end{array}$ & & & & $\checkmark$ & & \\
\hline 6 & 6 & $\begin{array}{l}\text { In this company, we maintain contacts with officials of } \\
\text { government and regulatory bodies in order to collect and } \\
\text { evaluate pertinent information. }\end{array}$ & & & & $\checkmark$ & & \\
\hline 7 & 5 & $\begin{array}{l}\text { In this company, we collect and evaluate information } \\
\text { concerning general social trends (e.g. environmental } \\
\text { concerns, emerging lifestyles) that might affect our } \\
\text { business }\end{array}$ & & & & $\checkmark$ & & \\
\hline 8 & 7 & In this company we do a lot of in-house market research. & $\checkmark$ & $\checkmark$ & $\checkmark$ & & & \\
\hline 9 & 8 & $\begin{array}{l}\text { We monitor our level of commitment and orientation to } \\
\text { serving customers' needs. }\end{array}$ & & & & & $\checkmark$ & \\
\hline 10 & 9 & $\begin{array}{l}\text { In this company, we meet with customers at least once a } \\
\text { year to find out what products or services they will need } \\
\text { in the future. }\end{array}$ & $\checkmark$ & 7 & $\checkmark$ & & & \\
\hline 11 & 10 & $\begin{array}{l}\text { We are slow to detect changes in our customers' } \\
\text { productiservice preferences }\end{array}$ & $\checkmark$ & $\checkmark$ & $\checkmark$ & & & $R$ \\
\hline 12 & 11 & $\begin{array}{l}\text { We poll end users at least once a year to assess the } \\
\text { guality of our products and services. }\end{array}$ & $\checkmark$ & $\checkmark$ & $\checkmark$ & $\checkmark$ & & \\
\hline 13 & 12 & $\begin{array}{l}\text { In this company, we spend time with our suppliers to } \\
\text { leam more about various aspects of their business (e.g. } \\
\text { manufacturing process, industry practices, clientele). }\end{array}$ & & & & $\checkmark$ & & \\
\hline 14 & 13 & $\begin{array}{l}\text { The top management team regularly discusses } \\
\text { competitors' strengths and strategies. }\end{array}$ & & & & & $\checkmark$ & \\
\hline
\end{tabular}

${ }^{15}$ The MKTOR items listed in this table were provided by the study of Farrel and Oczowski [1997] 


\begin{tabular}{|c|c|c|c|c|c|c|c|}
\hline 15 & 14 & $\begin{array}{l}\text { In this company, only a few people are collecting } \\
\text { competitor information }\end{array}$ & & & & $\checkmark$ & $R$ \\
\hline 16 & $\mathrm{~N} / \mathrm{A}$ & $\begin{array}{l}\text { Individuals from our manufacturing department interact } \\
\text { directly with customers to learn how to serve them better }\end{array}$ & & $\checkmark$ & & & \\
\hline 17 & N/A & $\begin{array}{l}\text { We are slow to detect changes in our customer's product } \\
\text { preferences }\end{array}$ & & $\checkmark$ & $\checkmark$ & & $R$ \\
\hline 18 & $\mathrm{~N} / \mathrm{A}$ & $\begin{array}{l}\text { We often talk with or survey those who can influence our } \\
\text { end users' purchases (e.g. retailers, distributors) }\end{array}$ & & $\checkmark$ & & & \\
\hline 19 & N/A & $\begin{array}{l}\text { We collect industry information by informal means (e.g. } \\
\text { lunch with industry friends, talks with trade partners) }\end{array}$ & & $\checkmark$ & & & \\
\hline 20 & N/A & $\begin{array}{l}\text { In our company, intelligence on our competitors is } \\
\text { generated independently by several departments }\end{array}$ & & $\checkmark$ & & & \\
\hline & & Responsiveness & & & & & \\
\hline 21 & 15 & $\begin{array}{l}\text { If a major competitor were to launch an intensive } \\
\text { campaign targeted at our customers we would implement } \\
\text { a response immediately. }\end{array}$ & $\checkmark$ & $\checkmark$ & $\checkmark$ & $\checkmark$ & \\
\hline 22 & 16 & $\begin{array}{l}\text { We tend to take longer than our competitors to respond } \\
\text { to a change in regulatory policy. }\end{array}$ & & & & $\checkmark$ & $\mathrm{R}$ \\
\hline 23 & 17 & $\begin{array}{l}\text { If a special interest group (e.g. consumer group, } \\
\text { environmental group) were to publicly accuse us of } \\
\text { harmful business practices, we would respond to the } \\
\text { criticism immediately. }\end{array}$ & & & & $\checkmark$ & \\
\hline 24 & 18 & $\begin{array}{l}\text { We are slow to start business with new suppliers even } \\
\text { though we think they are better than existing ones. }\end{array}$ & & & & $\checkmark$ & $\mathrm{R}$ \\
\hline 25 & 19 & $\begin{array}{l}\text { Several departments get together periodically to plan a } \\
\text { response to changes taking place in our business } \\
\text { environment. }\end{array}$ & $\checkmark$ & $\checkmark$ & $\checkmark$ & & \\
\hline 26 & 21 & $\begin{array}{l}\text { The activities of the different departments in this } \\
\text { company are well coordinated. }\end{array}$ & $\checkmark$ & $\checkmark$ & $\checkmark$ & $\checkmark$ & \\
\hline 27 & N/A & $\begin{array}{l}\text { A lot of informal "hall talk" in this company concerns our } \\
\text { competitors' tactics or strategies }\end{array}$ & & $\checkmark$ & & & \\
\hline 28 & $\mathrm{~N} / \mathrm{A}$ & $\begin{array}{l}\text { Our company periodically circulates documents (e.g. } \\
\text { reports, news letters) that provide information on our } \\
\text { customers }\end{array}$ & & $\checkmark$ & & & \\
\hline 29 & N/A & $\begin{array}{l}\text { When something important happens to a major customer } \\
\text { or market, the whole company knows about it within a } \\
\text { short period }\end{array}$ & & $\checkmark$ & $\checkmark$ & & \\
\hline 30 & N/A & $\begin{array}{l}\text { Data on customer satisfaction are disseminated at all } \\
\text { levels in this company on a regular basis }\end{array}$ & & $\checkmark$ & $\checkmark$ & & \\
\hline 31 & N/A & $\begin{array}{l}\text { There is minimal communication between marketing and } \\
\text { manufacturing departments concerning market } \\
\text { developments }\end{array}$ & & $\checkmark$ & & & $R$ \\
\hline 32 & N/A & $\begin{array}{l}\text { When one department finds out something important } \\
\text { about competitors, it is slow to alert other departments }\end{array}$ & & $\checkmark$ & $\checkmark$ & & $R$ \\
\hline & & Intelligence Dissemimation & & & & & \\
\hline 33 & 20 & $\begin{array}{l}\text { We have interdepartmental meetings at least once a } \\
\text { quarter to discuss market trends and developments. }\end{array}$ & $\checkmark$ & 7 & 7 & & \\
\hline 34 & 20 & $\begin{array}{l}\text { Marketing personnel in our company spend time } \\
\text { discussing customers' future needs with other functional } \\
\text { departments. }\end{array}$ & $\checkmark$ & $\checkmark$ & $\checkmark$ & $\checkmark$ & \\
\hline
\end{tabular}




\begin{tabular}{|c|c|c|c|c|c|c|c|}
\hline 35 & 20 & $\begin{array}{l}\text { We communicate information about our successful and } \\
\text { unsuccessful customer experiences across all business } \\
\text { functions. }\end{array}$ & & & & $\checkmark$ & \\
\hline 36 & 21 & $\begin{array}{l}\text { All of our business functions (e.g. marketing/sales, } \\
\text { manufacturing, R\&D) are integrated in serving the needs } \\
\text { of our target markets. }\end{array}$ & & & & $\checkmark$ & \\
\hline 37 & 22 & $\begin{array}{l}\text { All of our managers understand how everyone in our } \\
\text { company can contribute to creating customer value. }\end{array}$ & & & & $\checkmark$ & \\
\hline 38 & 20 & $\begin{array}{l}\text { We have cross-functional meetings very often to discuss } \\
\text { market trends and developments (e.g. customers, } \\
\text { competition, suppliers). }\end{array}$ & & & $\checkmark$ & & \\
\hline 39 & 20 & $\begin{array}{l}\text { We regularly have interdepartmental meetings to update } \\
\text { our knowledge of regulatory requirements. }\end{array}$ & & & $\checkmark$ & & \\
\hline 40 & 23 & $\begin{array}{l}\text { Technical people in this company spend a lot of time } \\
\text { sharing information about technology for new products } \\
\text { with other departments. }\end{array}$ & & & $\checkmark$ & & \\
\hline 41 & 24 & $\begin{array}{l}\text { Market information spreads quickly through all levels in } \\
\text { this company }\end{array}$ & & & $\checkmark$ & & \\
\hline 42 & N/A & $\begin{array}{l}\text { It takes us forever to decide how to respond to our } \\
\text { competitor's price changes }\end{array}$ & $\checkmark$ & $\checkmark$ & & & $\mathrm{R}$ \\
\hline 43 & N/A & $\begin{array}{l}\text { Principles of market segmentation drive new product } \\
\text { development efforts in this company }\end{array}$ & $\checkmark$ & & & & \\
\hline 44 & N/A & $\begin{array}{l}\text { For one reason or another we tend to ignore changes in } \\
\text { our customers' product or service needs }\end{array}$ & $\checkmark$ & $\checkmark$ & & & $\mathrm{R}$ \\
\hline 45 & N/A & $\begin{array}{l}\text { We periodically review our product development efforts to } \\
\text { ensure that they are in line with what customers want }\end{array}$ & $\checkmark$ & $\checkmark$ & & & \\
\hline 46 & N/A & $\begin{array}{l}\text { Our business plans are driven more by technological } \\
\text { advances than by market research }\end{array}$ & $\checkmark$ & & & & $\mathrm{R}$ \\
\hline 47 & N/A & $\begin{array}{l}\text { The product lines we sell depends more on internal } \\
\text { politics than real market needs }\end{array}$ & $\checkmark$ & & & & $\mathbf{R}$ \\
\hline 48 & N/A & Customer complaints fall on deaf ears in this company & $\checkmark$ & $\checkmark$ & & & R \\
\hline 49 & N/A & $\begin{array}{l}\text { Even if we came up with a great marketing plan, we } \\
\text { probably would not be able to implement it in a timely } \\
\text { fashion }\end{array}$ & $\checkmark$ & $\checkmark$ & & & $\mathrm{R}$ \\
\hline 50 & N/A & $\begin{array}{l}\text { We are quick to respond to significant changes in our } \\
\text { competitors' pricing structures }\end{array}$ & $\checkmark$ & & & & \\
\hline 51 & N/A & $\begin{array}{l}\text { When we find out that customers are unhappy with the } \\
\text { quality of our service, we take corrective action } \\
\text { immediately }\end{array}$ & $\checkmark$ & & & & \\
\hline 52 & N/A & $\begin{array}{l}\text { When we find that customers would like us to modify a } \\
\text { product or service, the departments involved make } \\
\text { concerted efforts to do so. }\end{array}$ & $\checkmark$ & $\checkmark$ & & & \\
\hline
\end{tabular}


Appendix B: Variable names 


\section{Variable names}

$\begin{array}{ll}\text { perfq1 } & \text { performance relative to company objectives } \\ \text { perfq2 } & \text { performance relative to major competitors } \\ \text { perfq3 } & \text { sales growth } \\ \text { perfq4 } & \text { market share growth } \\ \text { philq1 } & \text { production orientation } \\ \text { philq2 } & \text { sales orientation } \\ \text { philq3 } & \text { market orientation } \\ \text { momean } & \text { market orientation mean } \\ \text { mkmtmean } & \text { market turbulence mean } \\ \text { mkcpmean } & \text { competitive intensity mean } \\ \text { mkttmean } & \text { technological turbulence mean } \\ \text { mkdmmean } & \text { overall market demand mean } \\ \text { perfmean } & \text { performance mean } \\ \text { momkmt } & \text { market turbulence multiplicative interaction term } \\ \text { momkcp } & \text { competitive intensity multiplicative interaction term } \\ \text { momktt } & \text { technological turbulence multiplicative interaction term } \\ \text { momkdm } & \text { demand multiplicative interaction term } \\ \text { moigmean } & \text { intelligence generation component mean } \\ \text { moremean } & \text { responsiveness component mean } \\ \text { moidmean } & \text { intelligence dissemination component mean }\end{array}$


Appendix C: Questionnaire 


\section{Business Strategy and Performance Survey 2004}

Please answer the following questionnaire giving your opinion about your company or main strategic business unit, its business approach, practices, market conditions, and general outcomes. It should take about $10-15$ minutes to complete. Completion of all the questions is very important to our being able to do a complete analysis but you are free not to answer any question.

This questionnaire should be flled out by someone who has insight into the overall business strategy and operations of your organization. If there is someone in your organization who is better situated to complete the questionnaire, we would kindly ask you to pass it along to them.

A. To what extent do you agres with the following starements about your marker? (Please put an $X$ in the box that best retects your opinion)

In our kind of business, customers' productiservice preferences

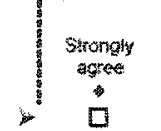

3ongwhic

Neither agres no somewhat strongly change quile a bil over time.

Our customers kend to look for new productsiservices all the time.

We are witnessing demand for our products and services from customers who never bought them before.

New customers tend to have product/service-related needs that are different from those of our existing customers.

We cater to many of the same customers that we used to in the past.

Competition in our industry is cutthroat.

There are many "promotion wars" in our industry.

Anything that one competitor can offer others can match readiy.

Price competition is halimark of our industry.

One hears of a new competive move almost every day.

Out competitors are relatively weak.

The technology in our industy is changing rapidy.

Technological changes provide big opportunities in our industry.

A large number of new product/service ideas have been made possible through technological breakthroughs in our industry.

Technological developments in our industry are rather minor.

Currently our market is experiencing high growth.

Currenty, in our marke. supply exceds demand. 
5. To what extent do you agre whth the tollowing statements abou your company? (Plasse put an X in the box that bast rellexts your opinion)

\begin{tabular}{|c|c|c|c|c|c|c|}
\hline & & & & & & \\
\hline $\begin{array}{l}\text { Out strategy for competitive advantage is based on out } \\
\text { understanding of customer needs. }\end{array}$ & 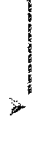 & $\begin{array}{l}\text { Susongly } \\
\text { iagies } \\
\square\end{array}$ & $\begin{array}{l}\text { Somathat } \\
\text { agree }\end{array}$ & 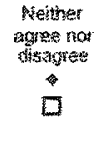 & $\begin{array}{l}\text { Sarrexituat } \\
\text { gisagree } \\
\$\end{array}$ & $\begin{array}{l}\text { Sirongly } \\
\text { disagre } \\
\square \\
\square\end{array}$ \\
\hline $\begin{array}{l}\text { Our business strategies are driven by our beliefs about how we } \\
\text { can create greater value for customers. }\end{array}$ & $>$ & $\square$ & $\square$ & $\square$ & $\square$ & $\square$ \\
\hline $\begin{array}{l}\text { We larget customers and customer groups where we have, or } \\
\text { can develop, competitive advantage. }\end{array}$ & $>$ & $D$ & $\square$ & 0 & 0 & $\square$ \\
\hline $\begin{array}{l}\text { We periodically review the likely eftect of changes in our } \\
\text { business environment (e.g. Jegulation) on customers. }\end{array}$ & 3 & $\mathbb{D}$ & $\square$ & $D$ & 0 & $\square$ \\
\hline $\begin{array}{l}\text { In this company, we frequently collect and evaluate general } \\
\text { macroeconomic and social trends information (e.g. interest rate, } \\
\text { exchange rate, GDF, industry growth rate, infiation rate, } \\
\text { environmental concerns, emerging lifestyles) that might affect } \\
\text { our business }\end{array}$ & $>$ & $B$ & $\square$ & $\square$ & $\mathbb{Q}$ & $\square$ \\
\hline $\begin{array}{l}\text { In this company, we maintain contacts with officials of } \\
\text { government and regulatory bodies in order to collect and } \\
\text { avautute perinent information. }\end{array}$ & in & $\square$ & $\square$ & D & $D$ & $\square$ \\
\hline In this company we do a lot of market research. & i & {[} & $\square$ & D & D & $\square$ \\
\hline $\begin{array}{l}\text { We monitor our level of commitment and orientation to serving } \\
\text { customers' needs. }\end{array}$ & $>$ & $\mathrm{D}$ & $\square$ & $\square$ & 0 & $D$ \\
\hline $\begin{array}{l}\text { In this company, we meet with cuslomers at least once a year to } \\
\text { find out what products or services they will need in the future. }\end{array}$ & $>$ & $\mathrm{D}$ & $\square$ & $\square$ & $\square$ & $\square$ \\
\hline $\begin{array}{l}\text { We are slow to detect changes in our customers' productservice } \\
\text { preferences. }\end{array}$ & $p$ & $\square$ & $\square$ & $\square$ & $\square$ & $\square$ \\
\hline $\begin{array}{l}\text { We poll end users at least once a year to assess the quality of } \\
\text { our products and services. }\end{array}$ & $>$ & $\square$ & $\square$ & $\mathrm{D}$ & 0 & $\square$ \\
\hline $\begin{array}{l}\text { In this company, we spend time with our suppliers to learn more } \\
\text { about various aspects of their business (e.g. manufacturing } \\
\text { process, incistry practices, clientele). }\end{array}$ & 7 & $\square$ & $\square$ & $\square$ & D & $\square$ \\
\hline $\begin{array}{l}\text { The top management team regularly discusses competitors' } \\
\text { strengths and strategies. }\end{array}$ & $\sigma$ & $\square$ & $\square$ & 0 & $\square$ & $\square$ \\
\hline $\begin{array}{l}\text { In this company, only a few people are collecting compettor } \\
\text { information }\end{array}$ & $\not$ & $\square$ & $\square$ & $\sqrt{3}$ & $\square$ & $\square$ \\
\hline $\begin{array}{l}\text { If a major compettor were to launch an intensive campaign } \\
\text { targeted at our customers we would implement a response } \\
\text { immediately. }\end{array}$ & $\ddot{z}$ & $\mathbb{E}$ & 0 & 5 & $\square$ & $\square$ \\
\hline $\begin{array}{l}\text { We lend to take longer than our compettors to respond to } \\
\text { change in regulatory policy. }\end{array}$ & $\not$ & $\mathrm{D}$ & 0 & $\square$ & 1 & 0 \\
\hline $\begin{array}{l}\text { If a special interest group (e.g. consumer group, environmental } \\
\text { group) ware to publicly accuse us of hamful bustims practices, } \\
\text { we would respond to the criticism immediately. }\end{array}$ & $>$ & $\square$ & 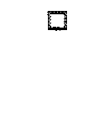 & $\square$ & $\Pi$ & $\square$ \\
\hline $\begin{array}{l}\text { We are slow to start business with new suppliers even though } \\
\text { we think they are better than existing ones. }\end{array}$ & 3 & $\square$ & $\square$ & 0 & $D$ & 0 \\
\hline $\begin{array}{l}\text { Several deparments get bgeiher periodicaly to plan tesponse } \\
\text { to changes taking dace in our business environment. }\end{array}$ & $>$ & $D$ & $\square$ & $\square$ & 0 & 0 \\
\hline
\end{tabular}
to changes taking place in our business environment. 
We regularly have interdepartmental meetings to discuss customer experiences and future needs, and market trends and developments (customers, competition, supplisers, regulatory requirements, etc.).

All of our business functions (e.g. marketing/sales, manufacturing, RaD) are integrated in serving the needs of our target markets.

All of our managers understand how everyone in our company can contribute to crealing customer value.

Technical people in this company spend a lot of time sharing information about technology for new products with other departments.

\begin{tabular}{|c|c|c|c|c|}
\hline $\begin{array}{l}\text { Strongly } \\
\text { axpree }\end{array}$ & Somentats & 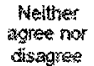 & $\begin{array}{l}\text { Someytha: } \\
\text { dicungee }\end{array}$ & $\begin{array}{l}\text { Stronghy } \\
\text { dristagret }\end{array}$ \\
\hline$\square$ & $\ddot{\square}$ & D & $\ddot{0}$ & $\mathbb{1}$ \\
\hline
\end{tabular}

Market intormation spreads quickly through all levels in this company

C. To what extent do you agre with the following statements about your company's overall strategy? (Please put an $X$ in the box that best rentects your opinion)

We attempl to locate and maintain a secure niche in a relatively stable product or service area. We tend to offer a more limited range of products or services than our competitors, and we try to proted its domain by offering higher quality, superior service, lower prices, elc.

We sypically operate within a broad product-market domain that undergoes periodic redefinition. We value being "first in" in new product and market areas even if not all of these efforts prove to be profitable.

\begin{tabular}{|c|c|c|c|c|}
\hline $\begin{array}{l}\text { strongly } \\
\text { natee }\end{array}$ & $\begin{array}{c}\text { Sunzewhat } \\
\text { agrese }\end{array}$ & 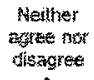 & $\begin{array}{l}\text { Somewhat } \\
\text { chiswgree }\end{array}$ & $\begin{array}{l}\text { Strongy } \\
\text { disagree }\end{array}$ \\
\hline$\square$ & $\square$ & D & 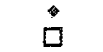 & 0 \\
\hline
\end{tabular}

We attempt to maintain a stable, limited line of products or services While at the same time moving quickly to follow a carefully selected set of the more promising new developments in the industry.

We are not usually as aggressive in maintaining established products and markets as some of our compelitors, or take as many risks as other compeliters, given that we are forced to spend our time responding to environmental pressures.

D. Flease rate the performance of your compomy fast yaar relativ to the following factors:

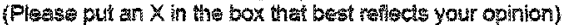

Our compeny's overall performance relative to company objectives

Our company's overall performance relative to major competitors

Our company's sales growth in our primary market.

Our company's market share growth in our primany market.

\begin{tabular}{|c|c|c|c|c|}
\hline $\begin{array}{c}\text { Exceltern } \\
\square\end{array}$ & $\ddot{\square}$ & $\ddot{\Delta}$ & $\square$ & $\begin{array}{c}\text { Yey poor } \\
\dot{\square}\end{array}$ \\
\hline 0 & $\square$ & 0 & $D$ & $\square$ \\
\hline$\square$ & $\square$ & $\square$ & $\square$ & $\square$ \\
\hline$\square$ & $\square$ & $\square$ & 0 & $\square$ \\
\hline
\end{tabular}


E. To what extent do you agree with the following statements about your company's overall philosophy? (Plase put an $X$ in the box that best reflects your opinion)

The key to business success is producing qualty goods and serwices at a reasonable cost. Good productsistrvices sell themserves. if possible, productsiservices should be standardize to keep costs down.

The key to business success lies in perstading potential customers to buy your goods and services through advertising. personal selling or other means. Potential customers must be intonred and convinced a the benefits of the products.

The key to business success is to integrate all company activites and personnel towards satisfying customers, while providing satisfactory profts to the firm. The firm should ind out what benefits customers want

\begin{tabular}{|c|c|c|c|c|}
\hline $\begin{array}{c}\text { Strongly } \\
\text { agree }\end{array}$ & $\begin{array}{l}\text { Somestutat } \\
\text { agres }\end{array}$ & 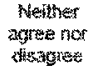 & $\begin{array}{c}\text { Somethat } \\
\text { gisagree }\end{array}$ & $\begin{array}{l}\text { Strongly } \\
\text { ixisagree }\end{array}$ \\
\hline$\square$ & 문 & 0 & $\stackrel{4}{\square}$ & $\ddot{\square}$ \\
\hline
\end{tabular}
and then provide these benefits through goods and services.

F. To houp classify your answers please tenl us littlo about yoursolf and your company: What ts your current position? Current Position

How many employes are in your company?

What are the annual sales of your company? Employass

In what year was your company established? Annual sales in $C A D$

What is the primary produci/service offered by your company? Year establisinec Froductservice

If there's anything you wowld inke to tell ts about the major fronds or factors currenty attecting your industry or any other topics of this survey, please do go in the space provided below.

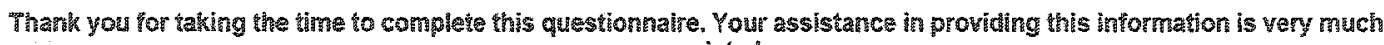
appraciated.

Ir you have any questions, please contact us by phone or email:

Dr. Loutse Hislop. Proisssor

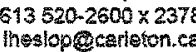

Please return your completed questionnaire in the postago-pard envelope provided to the following address by dine 18 th

$$
\begin{aligned}
& \text { Dr. Louise Haslop, Professor } \\
& \text { Sprot School of Business } \\
& \text { Cariston University } \\
& 1125 \text { Colonel By Dive } \\
& \text { Ottawa. ON K } 1586
\end{aligned}
$$

Also, please rewin the postage paid card separately to obtain a copy of the results. Thank you. 
Appendix D: Cover letter, first round 

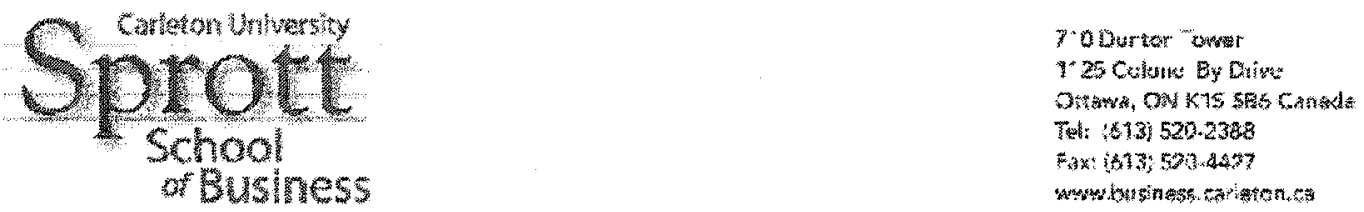

Mir Armen Kazxan

President

ARP Products

2300 Rue, Victoria

Lachine, $\mathrm{ON}$

K2K 2B4, Canada

Dear Mr. Zazaan,

Canadia companys are facing growing national and intemational competition, tougher matket conditions, and increasingly selective customers, making it more and more difficult to meet business performance goals. Choosing the right business strategy that makes sense in the conditions aced is critical to success in these clallenging tines. As competition and narket situations change, business managers, like yourself, must make many decisions each day that reflect your business strategy and have both short and long-term impacts on the perfonnance of your business. Are these decisions well suited to company goals, the competitive enviromment, and the changing demands of your buyers?

To help Canadin companys choose the most effective business strategy for their simation, at Carleton Univerity's Sprott School of Business we are carying ont a study of Canadian corporate behaviors, market conditions and business performance. Resulis from the study will be used to develop business strategy recommendatious tailored to different industries and the envirouments they face.

The results of the enclosed survey will be compled and, at your request, will be returned to you to enable you to compare you business practice with other businesses in a range of industries. Cross-industry comparisons will allow you to benolmak your practices with those of others in your industry with similar goals, age and stage of development, and with those in other intustries. These results will help you choose successtul business stategies and increase yout organization ${ }^{2} \mathrm{~s}$ business perfomance.

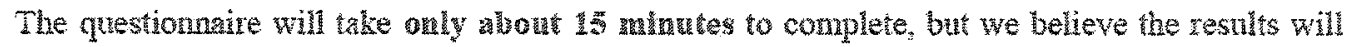
be of significant worth to you. We value your time and will provithe feedback to yoll guickly. In order to do so, we need your completed questionnare returned to us (in the postage-paid envelope provided within the next wo weers. 
Appendix E: Cover letter, second round 
Appendix F: Return post card 


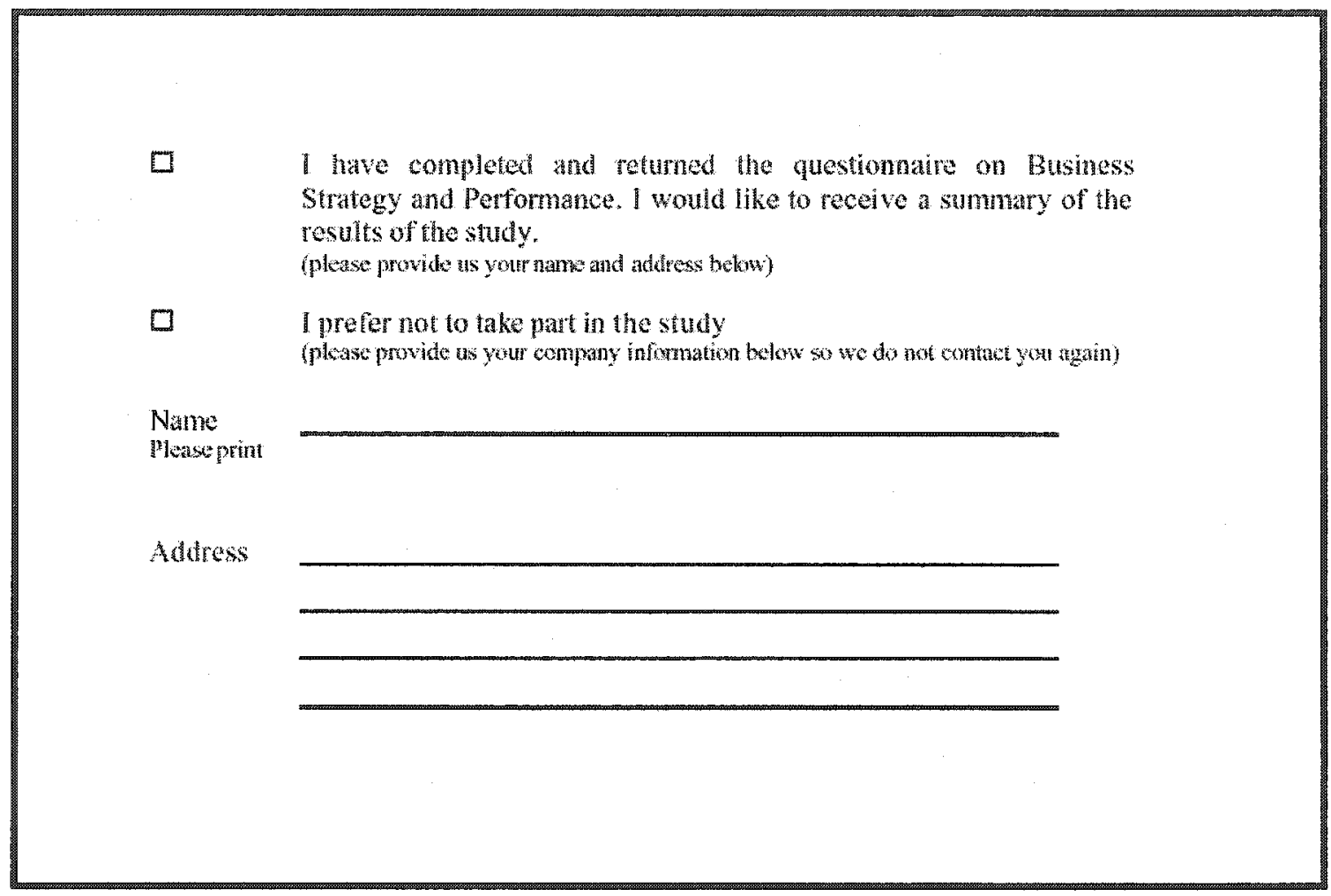


Appendix $\mathrm{G}$ : Cover letter, results to respondents 
Appendix H: Results to respondents 


\title{
Canadian corporate strategies and behaviors, market conditions and business performance: A summary report for study participants
}

\author{
Dr. Louise A. Heslop \\ Alain Rojas, MBA candidate \\ Sprott School of Business, Carteton University
}

The puppose of this study was to find whether a specinic business strategic approach would predict better business performance and whether the type of industy makes a difference in "best" strategy. Three strategic approacles have been identified in earlier research - a market onientation, a product orientation, and a sales orientition. Many earlier studies bave found that a "market orientation" strategy is the most effective approach. However, the question is whether this is true today in Canade and under current situations faced by some industries. In particular, the techuology sector has weathered particulaty turbulent times and a major decrease in market denand. Also, some industries, including technology industries face situations of rapid teclmology changes and changes in customer needs. In particular, the environmental conditions that miglat influence the effectiveness of a market orientation that were examined were - maket tubulence, competitive inteasity, teclmological tubulence, and market demmin.

The model for the study is indicated below.

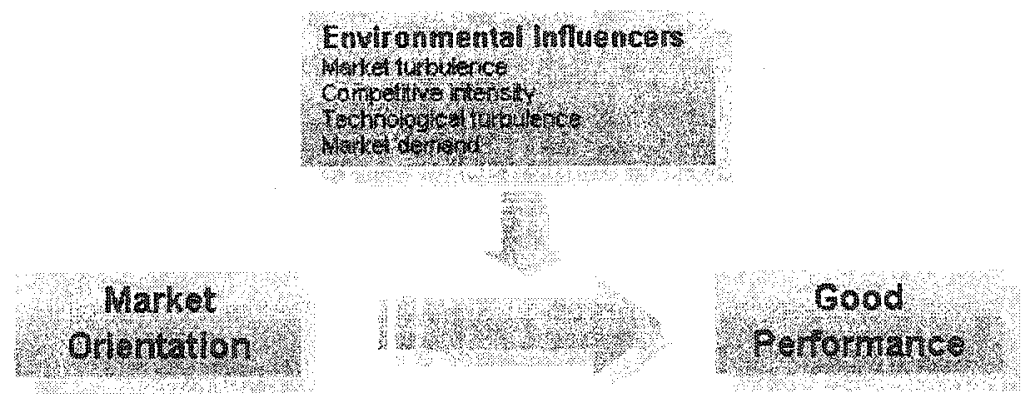

Lastly, the study tried to find differences between the effectiveness of a market onientation for fims in the telecommunications industry and firms in the rest of the manufacturing indnstry sectors. The recent downum in the telecommunications industry suggests that the results of this study might be useful to help finns in that industry weather the shump.

\section{Summary of results}

The results from the study dowed that businesses with a high market orientation are more likely to experience:

1. high overall businests performance

2. high performance nelative to their najor competitors

3. High sales growth, and,

4. high matket shere growth 
The results showed that if a company is experiencing low demand or high competition, then a market orientation is critical to achieving high business perfomance. However, they also indicated for those organizations experiencing high denand and low competition, a high market orientation leads to higher organization performance directly and also enhances the effectiveness of the market orientation in supporting high business perfomance.

Additionally, the results showed that a market onientation is even more critical for companies in the telecommunications sector. The natket onientation effects are as strong as they are in other sectors and operate without regard to issues of teclnology or market turbulence. That is, even though markets and technology are evolving rapidy and regardless of demand and competition levels, keeping an eye on customers and building their needs across all the organization is what makes for high performance.

The results from the stady are explained in detail below.

\section{Respondent profille}

The results where derived from responses by presidents, CEO's and top managers of 152 Canadia companys in the manufacturing industy, and about half of these were from organizations with their main business in the telecomununications indistry in Canada. The responding organizations varied by size, fiom 4 to 800 enployees, and from $\$ 1$ Million to $\$ 250$ Million in annual sales. Most had less than 100 employees and sales of \$1-25 Million. In general, it was found that the responding organizations where highly representative of the general manufacturing industry population of Canada and the findings can be interpreted as reflective of Canadian industry conditions.

\section{Market Orientation}

The results showed a significant positive relationship between the "market orientation" of a conpany and its business petformance. A company that has a market orientation will:

1. have a customer focus across the entire organization and all its deparments

2. place special enplasis in understanding its market, its competitors and its custoners

3. design its products using the understanding mentioned in the previous point, without departing from its overall mission, experience and skills.

Besides a market orientation, other altemate business strategies exist: mainly a product orientation and a sales orientation. A product orientation focuses on the organization's products instead of the market, so prodnction and engineering executives rua the organization. They base their business decision on developing a good product, and the assumption that a good product will natually sell. $A$ sales onieutation is focused on sales, so the marketing and sales deparments mu the organization. Advertising and product pronotion are the basis of this bnsiness strategy. Many earlier studies have found that a "market orientation" strategy is the most effective approacl of the three.

In general, a market-oriented company will continuously engage in three main activities:

1. The generation of market intelligence,

2. The dissemination of market inteligence thronglout the entire organization

3. The generation of actionable strategies based on the market intelligence obtained. 
Businesses that have a market onientation will cary out all or most of the following activities:

- Periodically review the likely effects of changes in their business enviromment (e.g. regulation) on customers.

- Collect and evaluate information concening general social trends (e.g. envirommental concems. emerging lifestyles) that might affect their business

- Carry out market research.

- Meet with customers at least once a year to find out what products or services they will need in the future.

- Be attentive to changes in customers' product'service preferences.

- Be attentive and quick to respond to competitors' strategies and marketing campaigns aimed at customers

- Make sure key deparments in the organization get togetiler periodically to plan a response to changes faking place in the business environment

- Make sure the activities of the different departments in the company are well coordinated

- Have interdepartmental nieetings at least once a quarter to discuss market trends and developments.

- Make sure marketing personnel spend time discussing customers furure needs with other functional departnents.

\section{Business Performance}

Business performance was measured relative to:

- a company's overall objectives

- its major competitors

- the company's sales growth

- its mauket share growth

The results from the study showed that a market orientation helped a company experience a high business perfonnance in all the aspects measured. In other words, if businesses with a market onientation increase their chances of lwing higher performance than competitors, increase their likelhood of haviug high sales as well as incrementing market share. and increase their chances of having high perfomance relative to organizational goals.

\section{Envirommental influencers}

The results of the stukly also showed interesting effects of the environmental factors surounding an industry on a company's bisiness pertormance, ats well as an effect on the effectiventess of a company's market orientation on performance. Four extemal factors where sadied:

- Market turbulence

- Competitive intensity

- Technological turbulence

- Market denand

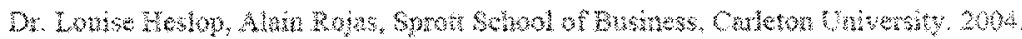

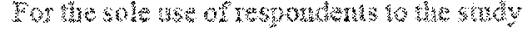

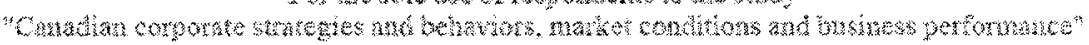


Market tubulence refers to how cuickly the customer's needs and wants change in a specific industry. High market turbulence means that a customer's preferences change significanty over a short period of time. Low market turbulence would nean that customer preferences seldom change. Competitive intensity refers to the quantity and aggressiveness of a company's competition. Technological turbulence refers to the importance and significance of tecinology and innovativeness in an indusiry. High tech industries generally experience high rechnological tubulence. Market demand refers to the quantity of demand experienced by an industry. Several industries experience constant demand, while others liave seasonal demand or experience a period of high or low demand over time.

The results of the study showed that high demand and low competitive intensity positively affect a company's performance. This is clear and not unexpected on an absolute level, but also holds true for relative performance. However, the results also showed that if demand is low and competition is high, it is very important for a company to choose a market orientation strategy to realize strong perfornance.

The results of the study showed that technological tubulence and market fubulence did not inpact finm performance or the impotance of a market orientation to successful perfomance. In other words, even when technology and matket demands are changing quickly, businesses that address asstoner needs through a maket orientation strategy approach will be more successfil.

Additionally, the results showed that issnes of market and technology twoulence do not affect organizations in the telecommunications industry as moln as companies in the rest of the manufacturing industry sectors. This means that a maket orientation is even more critical for telecommunications companies. Their performance is more dependent on strategy choice and less dependent on conditions of market, competition, and tecinology evolution.

Summing up, five conclusions were obtained from the results of the study:

1. A conpany will always beneft from a narket orientation

2. High denand and low competition will help achieve good business performance, but even inder tiese conditions, a narke onentaton means better perfommance

3. The inpotance of nainaining a maiket orientation becones even nore apparent when demaud begins to lag andor compertion begin to ncrease

4. Both Ingh and low tech ndustres benefit fon a maket cientation and the advantage is not lower for industres experencing rapid tednology changes

5. Anaket onentaton benefits organzations with customers whose needs and demands ate evolving repidly as well as hose with nore stable needs

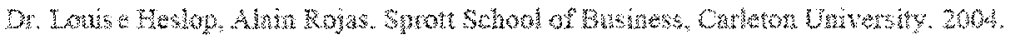

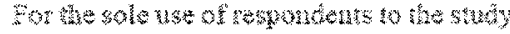

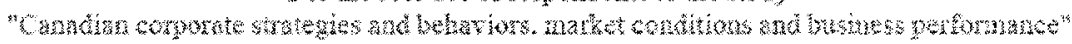


Appendix 1: Results 
1.1 Histograms or mean variables

Figure 6. Market orientation, momean, histogram

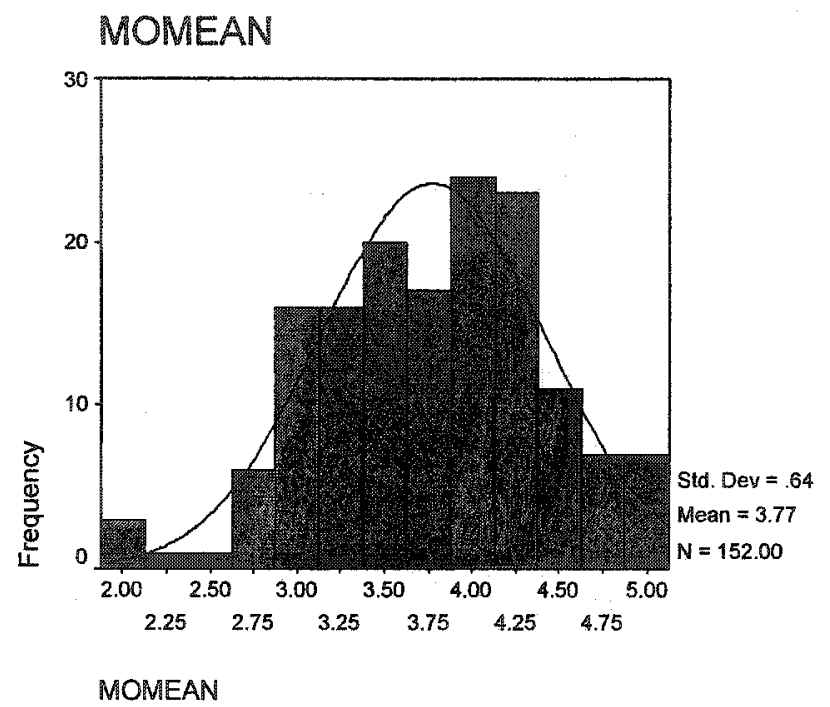

Figure 7. Market turbulence, mkmtmean, histogram

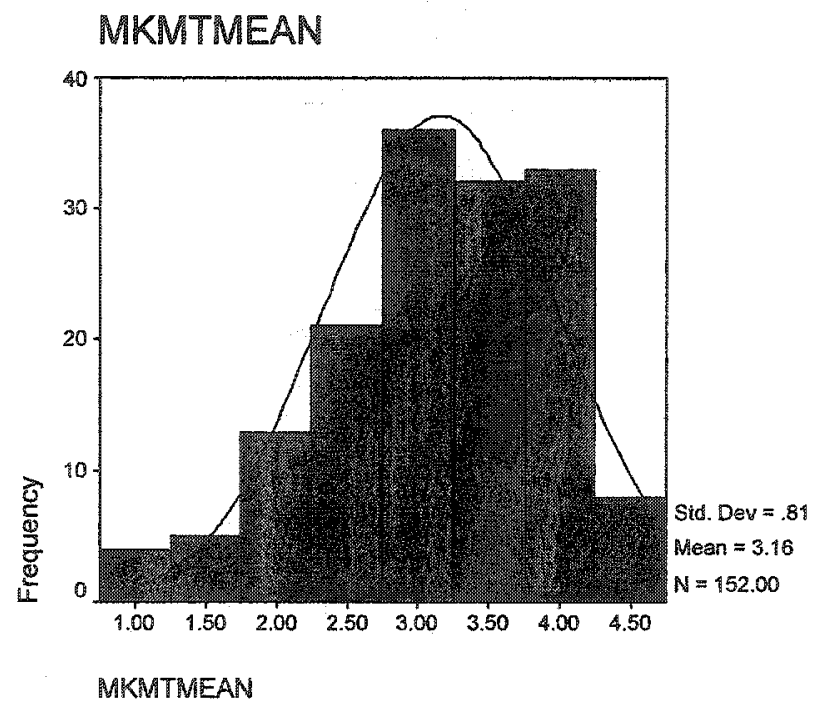


Figure 8. Competitive intensity, mkcpmean, histrogram

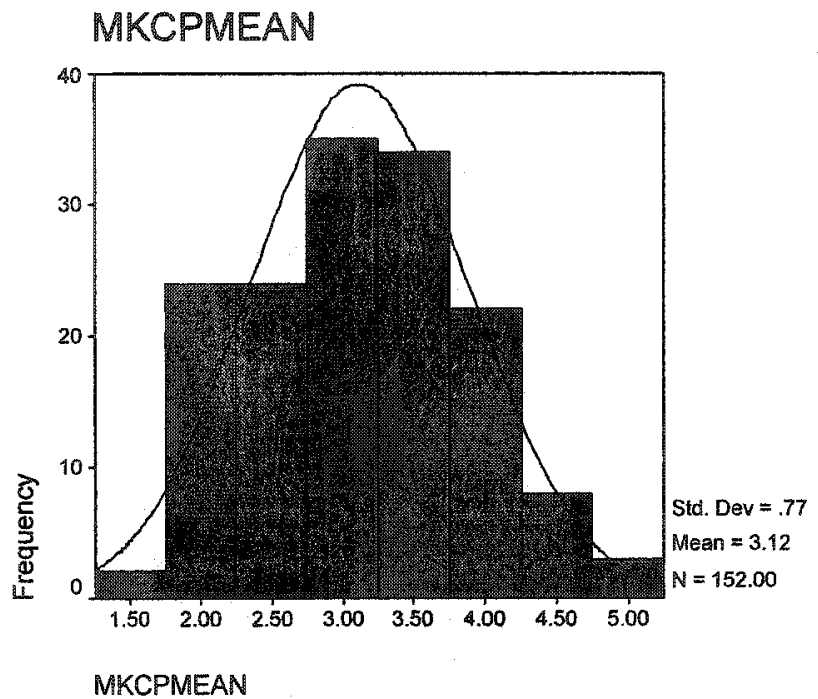

Figure 9. Technological turbulence, mkttmean, histogram

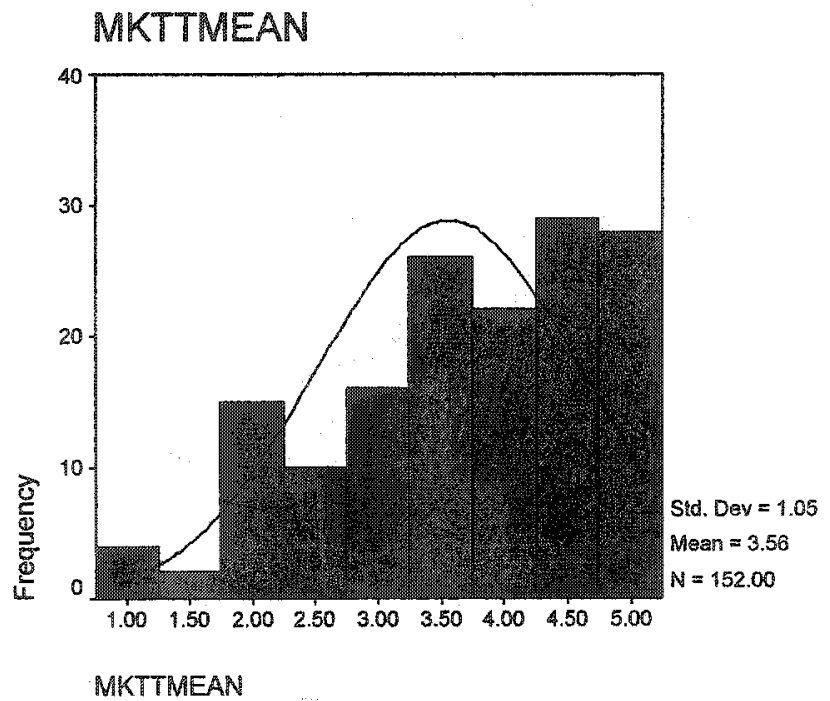


Figure 10. Demand, mkdmmean, histogram

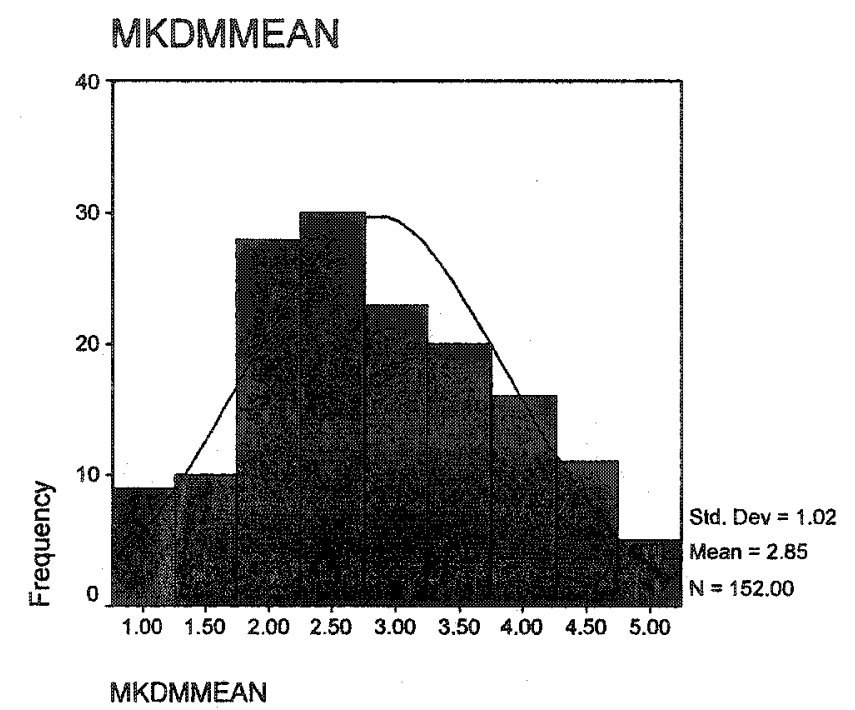

Figure 11. Performance, perfmean, histogram

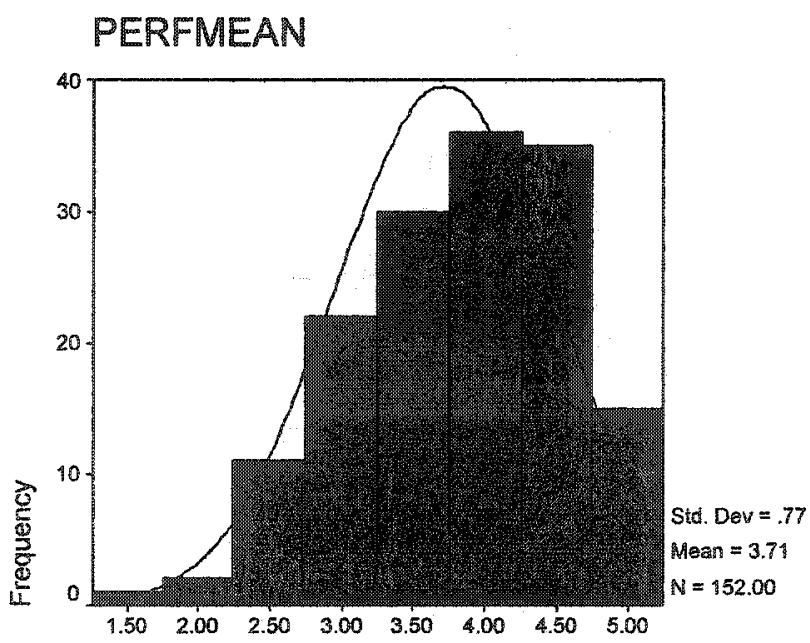

PERFMEAN 
.2 Crombach's alpha

Market Orientation (momean)

List of items

- MOIGQ4 Intelligence generation q4

- MOIGQ7 Intelligence generation 97

- MOIGQ9 Intelligence generation q9

- MOIGQ10 Intelligence generation q10 reversed

- MOIGQ11 Intelligence generation q11

- MOREQ1 responsiveness $q 1$

- MOREQ5 responsiveness q5

- MOIDQ1 intelligence dissemination q1

- MOIDQ2 intelligence dissemination q2

alpha $=.7569$

alpha if item deleted

- MOIGQ4 $\quad .7346$

- MOIGQ7 $\quad .7379$

- MOIGQ9 $\quad .7335$

- MOIGQ10 $\quad .7462$

$\begin{array}{ll}\text { - MOIGQ11 } & .7504\end{array}$

- MOREQ1 $\quad .7385$

- MOREQ5 $\quad .7174$

- MOIDQ1 $\quad .7257$

- MOIDQ2 $\quad .7269$ 
Market turbulence (mkmtmean)

List of items

- MKMTQ1 market turbulence q1

- MKMTQ2 market turbulence q2

- MKMTQ3 market turbulence $q^{3}$

- MKMTQ4 market turbulence q4

- MKMTQ5 market turbulence q5 rev

alpha $=.7272$

alpha if item deleted

- MKMTQ1 .6720

- MKMTQ2 $\quad .6132$

- MKMTQ3 .6426

- MKMTQ4 .6764

- MKMTQ5 $\quad .7680$

Market competitiveness (mkcpmean)

List of items

- MKCMPQ1 market competitiveness q1

- MKCMPQ2 market competitiveness q2

- MKCMPQ3 market competitiveness q3

- MKCMPQ4 market competitiveness q4

- MKCMPQ5 market competitiveness q5

- MKCMPQ6 market competitiveness q6 rev

alpha $=.7408$ 
alpha if item deleted

- MKCMPQ1 $\quad 6973$

- MKCMPQ2 .6873

- MKCMPQ3 $\quad .6747$

- MKCMPQ4 $\quad .6810$

- MKCMPQ5 $\quad .6968$

- MKCMPQ6 $\quad .7726$

Technological Turbulence (mkttmean)

- MKTTQ1 market technology q1

- MKTTQ2 market technology q2

- MKTTQ3 market technology q3

- MKTTQ4 market technology q4

alpha $=.8866$

alpha if item deleted

- MKTTQ1 .8448

- MKTTQ2 .8453

- MKTTQ3 .8591

- MKTTQ4 $\quad .8678$

Overall market demand (mkdmmean)

- MKDEMQ1 market demand q1

- MKDEMQ2 market demand q2 
alpha $=.5876$

alpha if item deleted

- MKDEMQ1 N/A

- MKDEMQ2 N/A

Performance (perfmean)

- PERFQ1 performance relative to company objectives

- PERFQ2 performance relative to competitors

- PERFQ3 sales growth

- PERFQ4 market share growth

alpha $=.8450$

alpha if item deleted

- PERFQ1 .8105

- PERFQ2 8251

- PERFQ3 $\quad .7841$

- PERFQ4 .7883 


\subsection{Criterion Validity}

Table 31. Regression of momean vs, perfmean

Model Summary

\begin{tabular}{|l|r|r|r|r|}
\hline Model & $R$ & R Square & $\begin{array}{c}\text { Adjusted } \\
\text { R Square }\end{array}$ & $\begin{array}{c}\text { Std. Error of } \\
\text { the Estimate }\end{array}$ \\
\hline 1 & $.238^{2}$ & .057 & .037 & .75130 \\
\hline
\end{tabular}

a. Predictors: (Constant), MOIDMEAN, MOIGMEAN, MOREMEAN

ANOVA

\begin{tabular}{|c|c|c|c|c|c|c|}
\hline Model & & $\begin{array}{l}\text { Sum of } \\
\text { Squares }\end{array}$ & $d f$ & Mean Square & $F$ & Sig. \\
\hline \multirow[t]{3}{*}{1} & Regression & 5.013 & 3 & 1.671 & 2.961 & $.034^{2}$ \\
\hline & Residual & 83.538 & 148 & .564 & & \\
\hline & Total & 88.551 & 151 & & & \\
\hline
\end{tabular}

a. Predictors: (Constant), MOIDMEAN, MOIGMEAN, MOREMEAN

b. Dependent Variable: PERFMEAN

Coefficients $^{2}$

\begin{tabular}{|c|c|c|c|c|c|c|}
\hline \multirow[b]{2}{*}{ Model } & & \multicolumn{2}{|c|}{$\begin{array}{l}\text { Unstandardized } \\
\text { Coefficients }\end{array}$} & \multirow{2}{*}{$\begin{array}{c}\begin{array}{c}\text { Standardized } \\
\text { Coefficients }\end{array} \\
\text { Beta }\end{array}$} & \multirow[b]{2}{*}{1} & \multirow[b]{2}{*}{ Sig. } \\
\hline & & $B$ & Std. Error & & & \\
\hline \multirow[t]{4}{*}{1} & (Constant) & 2.729 & .377 & & 7.231 & .000 \\
\hline & MOIGMEAN & .202 & .105 & .188 & 1.927 & .056 \\
\hline & MOREMEAN & 6.801E-02 & .092 & .077 & .737 & .462 \\
\hline & MOIDMEAN & -4.67E-04 & .100 & .000 & -.005 & .996 \\
\hline
\end{tabular}

a. Dependent Variable: PERFMEAN 


\subsection{Construct Validity}

Table 32. Correlations between momean and a set of descriptions of business philosophies

\begin{tabular}{|ll|r|r|r|r|}
\hline & & MOMEAN & phil q1 & phil q2 & phil q3 \\
\hline MOMEAN & Pearson Correiation & 1 & .152 & .104 & $.302^{* 1}$ \\
& Sig. (2-tailed) &. & .062 & .201 & .000 \\
& $\mathrm{~N}$ & 152 & 152 & 152 & 152 \\
\hline philosophy q1 & Pearson Correlation & .152 & 1 & .128 & -.007 \\
& Sig. (2-tailed) & .062 &. & .115 & .933 \\
& $\mathrm{~N}$ & 152 & 152 & 152 & 152 \\
\hline philosophy q2 & Pearson Correlation & .104 & .128 & 1 & $.204^{*}$ \\
& Sig. (2-tailed) & .201 & .115 &. & .012 \\
& $\mathrm{~N}$ & 152 & 152 & 152 & 152 \\
\hline philosophy q3 & Pearson Correlation & $.302^{* *}$ & -.007 & $.204^{*}$ & 1 \\
& Sig. (2-tailed) & .000 & .933 & .012 &. \\
& $\mathrm{~N}$ & 152 & 152 & 152 & 152 \\
\hline
\end{tabular}

* Correlation is significant at the 0.01 level (2-talled).

* Correlation is significant at the 0.05 level (2-tailed). 
Table 33. Correlations between market (environmental) variables

\begin{tabular}{|c|c|c|c|c|c|}
\hline & & MKMTMEAN & MKCPMEAN & MKTTMEAN & MKDMMEAN \\
\hline \multirow[t]{3}{*}{ MKMTMEAN } & Pearson Correlation & 1 & $.223^{* * 4}$ & $.462^{* * 4}$ & .103 \\
\hline & Sig. (2-tailed) & - & .006 & .000 & .207 \\
\hline & N & 152 & 152 & 152 & 152 \\
\hline \multirow[t]{3}{*}{ MKCPMEÁN } & Pearson Correlation & $.223^{*+1}$ & 1 & .098 & $-.218^{*+1}$ \\
\hline & Sig. (2-tailed) & .006 & . & .230 & .007 \\
\hline & N & 152 & 152 & 152 & 152 \\
\hline \multirow[t]{3}{*}{ MKTTMEAN } & Pearson Correlation & $.462^{*+4}$ & .098 & 1 & $.350^{*}$ \\
\hline & Sig. (2-tailed) & .000 & .230 & . & .000 \\
\hline & $N$ & 152 & 152 & 152 & 152 \\
\hline \multirow[t]{3}{*}{ MKDMMEAN } & Pearson Correlation & .103 & $-.218^{* \times}$ & $.350^{*+4}$ & 1 \\
\hline & Sig. (2-tailed) & .207 & .007 & .000 & \\
\hline & $N$ & 152 & 152 & 152 & 152 \\
\hline
\end{tabular}

**. Correlation is significant at the 0.01 level (2-tailed). 


\subsection{Model 1}

Table 34. Regression of MOMEAN vs. Performance relative to company objectives

Model Summary

\begin{tabular}{|l|r|r|r|r|}
\hline Model & $\mathrm{R}$ & $\mathrm{R}$ Square & $\begin{array}{c}\text { Adjusted } \\
\text { R Square }\end{array}$ & $\begin{array}{c}\text { Std. Error of } \\
\text { the Estimate }\end{array}$ \\
\hline 1 & $.183^{2}$ & .034 & .027 & .932 \\
\hline
\end{tabular}

a. Predictors: (Constant), MOMEAN

ANOVAb

\begin{tabular}{|ll|r|r|r|r|r|}
\hline Model & $\begin{array}{r}\text { Sum of } \\
\text { Squares }\end{array}$ & df & Mean Square & F & Sig. \\
\hline 1 & Regression & 4.535 & 1 & 4.535 & 5.220 & $.024^{a}$ \\
& Residual & 130.307 & 150 & .869 & & \\
Total & 134.842 & 151 & & \\
\hline
\end{tabular}

a. Predictors: (Constant), MOMEAN

b. Dependent Variable: performance $q 1$

Coefficients

\begin{tabular}{|c|c|c|c|c|c|c|}
\hline \multirow{2}{*}{\multicolumn{2}{|c|}{ Model }} & \multicolumn{2}{|c|}{$\begin{array}{c}\text { Unstandardized } \\
\text { Coefficients }\end{array}$} & \multirow{2}{*}{$\begin{array}{c}\text { Standardized } \\
\text { Coefficients } \\
\text { Beta }\end{array}$} & \multirow[b]{2}{*}{$t$} & \multirow[b]{2}{*}{ Sig. } \\
\hline & & 8 & Std. Error & & & \\
\hline & (Constant) & 2.664 & .453 & & 5.882 & .000 \\
\hline & MOMEAN & .271 & .118 & .183 & 2.285 & .024 \\
\hline
\end{tabular}

a. Dependent Variable: performance of 
Table 35. Regression of MOMEAN vs. Performance against competitors

Model Summary

\begin{tabular}{|c|c|c|c|c|}
\hline Model & $\mathbb{R}$ & R Square & $\begin{array}{l}\text { Adjusted } \\
\text { R Square }\end{array}$ & $\begin{array}{l}\text { Std. Error of } \\
\text { the Estimate }\end{array}$ \\
\hline 1 & $.170^{a}$ & .029 & .022 & .742 \\
\hline
\end{tabular}

a. Predictors: (Constant), MOMEAN

\begin{tabular}{|c|c|c|c|c|c|c|}
\hline \multicolumn{7}{|c|}{ ANOVA } \\
\hline \multicolumn{2}{|c|}{ Model } & $\begin{array}{l}\text { Sum of } \\
\text { Squares }\end{array}$ & df & Mean Square & $\mathrm{F}$ & Sig. \\
\hline \multirow[t]{3}{*}{1} & Regression & 2.447 & 1 & 2.447 & 4.449 & $.037^{a}$ \\
\hline & Residual & 82.494 & 150 & .550 & & \\
\hline & Total & 84.941 & 151 & & & \\
\hline
\end{tabular}

a. Predictors: (Constant), MOMEAN

b. Dependent Variable: performance $q 2$

\section{Cooticiente}

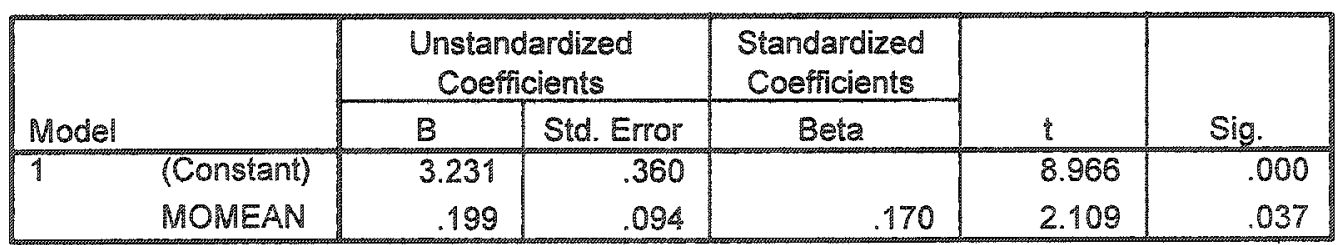

a. Dependent Variable: performance $q_{2}$ 
Table 36. Regression of MOMEAN vs. sales growth performance

Model Summary

\begin{tabular}{|l|r|r|r|r|}
\hline Model & R & R Square & $\begin{array}{c}\text { Adjusted } \\
\text { R Square }\end{array}$ & $\begin{array}{c}\text { Std. Error of } \\
\text { the Estimate }\end{array}$ \\
\hline 1 & $.181^{2}$ & .033 & .026 & 1.010 \\
\hline
\end{tabular}

a. Predictors: (Constant), MOMEAN

ANOVA

\begin{tabular}{|ll|r|r|r|r|r|}
\hline Model & \multicolumn{1}{|c|}{$\begin{array}{c}\text { Sum of } \\
\text { Squares }\end{array}$} & df & Mean Square & $F$ & Sig. \\
\hline 1 & Regression & 5.174 & 1 & 5.174 & 5.075 & $.026^{a}$ \\
& Residual & 152.925 & 150 & 1.019 & & \\
& Total & 158.099 & 151 & & & \\
\hline
\end{tabular}

a. Predictors: (Constant), MOMEAN

b. Dependent Variable: performance q3

Coerticients

\begin{tabular}{|c|c|c|c|c|c|c|}
\hline \multirow{2}{*}{\multicolumn{2}{|c|}{ Modeî }} & \multicolumn{2}{|c|}{$\begin{array}{c}\text { Unstanderdized } \\
\text { Coefficients }\end{array}$} & \multirow{2}{*}{$\begin{array}{l}\text { Standardized } \\
\text { Coefficients } \\
\text { Beta }\end{array}$} & \multirow[b]{2}{*}{ t } & \multirow[b]{2}{*}{ Sig. } \\
\hline & & $B$ & Std. Error & & & \\
\hline & (Constant) & 2.522 & .491 & & 5.141 & .000 \\
\hline & MOMEAN & .289 & .128 & .181 & 2.253 & .026 \\
\hline
\end{tabular}

a. Dependent Variable: performance $q^{3}$ 
Table 37. Regression of MOMEAN vs. market share growth performance

Model summary

\begin{tabular}{|l|r|r|r|r|}
\hline Model & $R$ & R Square & $\begin{array}{c}\text { Adjusted } \\
\text { R Square }\end{array}$ & $\begin{array}{l}\text { Std. Error of } \\
\text { the Estimate }\end{array}$ \\
\hline 1 & $.230^{\circ}$ & .053 & .047 & .944 \\
\hline
\end{tabular}

a. Predictors: (Constant), MOMEAN

ANOVA

\begin{tabular}{|ll|r|r|r|r|r|}
\hline Model & $\begin{array}{c}\text { Sum of } \\
\text { Squares }\end{array}$ & df & Mean Square & F & Sig. \\
\hline 1 & Regression & 7.485 & 1 & 7.485 & 8.406 & $.004^{2}$ \\
& Residual & 133.568 & 150 & .890 & & \\
Total & 141.053 & 151 & & \\
\hline
\end{tabular}

a. Predictors: (Constant), MOMEAN

b. Dependent Variable: performance $q 4$

Coekicients

\begin{tabular}{|c|c|c|c|c|c|c|}
\hline \multirow{2}{*}{\multicolumn{2}{|c|}{ Model }} & \multicolumn{2}{|c|}{$\begin{array}{c}\text { Unstandardized } \\
\text { Coeflicients }\end{array}$} & \multirow{2}{*}{$\begin{array}{c}\text { Standardized } \\
\text { Coefficients } \\
\text { Beta }\end{array}$} & \multirow[b]{2}{*}{ 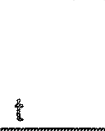 } & \multirow[b]{2}{*}{ Sig. } \\
\hline & & $B$ & Std. Error & & & \\
\hline \multirow[t]{2}{*}{1} & (Constant) & 2.268 & .459 & & 4.947 & .000 \\
\hline & MOMEAN & .348 & .120 & .230 & 2.899 & .004 \\
\hline
\end{tabular}

a. Dependen Variable: pertormance 94 


\subsection{Model 3}

\subsubsection{Market turbulence multiplicative interaction term}

Table 38. Regression using market turbulence multiplicative interaction term vs. performance relative to company objectives

Model Summary

\begin{tabular}{|l|r|r|r|r|}
\hline Model & \multicolumn{1}{|c|}{$R$} & R Square & $\begin{array}{l}\text { Adjusted } \\
\text { R Square }\end{array}$ & $\begin{array}{c}\text { Std. Error of } \\
\text { the Estimate }\end{array}$ \\
\hline 1 & $.405^{\circ}$ & .164 & .129 & .882 \\
\hline
\end{tabular}

a. Predictors: (Constant), MOMKMT, MKDMMEAN, MKCPMEAN, MKTTMEAN, MOMEAN, MKMTMEAN

\section{ANOVA}

\begin{tabular}{|c|c|c|c|c|c|c|}
\hline Model & & $\begin{array}{l}\text { Sum of } \\
\text { Squares }\end{array}$ & $d f$ & Mean Square & $F$ & Sig. \\
\hline \multirow[t]{3}{*}{1} & Regression & 22.116 & 6 & 3.686 & 4.741 & $.000^{\mathrm{a}}$ \\
\hline & Residual & 112.727 & 145 & .777 & & \\
\hline & Total & 134.842 & 151 & & & \\
\hline
\end{tabular}

a. Predictors: (Constant), MOMKMT, MKDMMEAN, MKCPMEAN, MKTTMEAN, MOMEA MKMTMEAN

b. Dependent Variable: performance $q 1$

\section{Coefficients}

\begin{tabular}{|c|c|c|c|c|c|c|}
\hline \multirow{2}{*}{\multicolumn{2}{|c|}{ Model }} & \multicolumn{2}{|c|}{$\begin{array}{c}\text { Unstandardized } \\
\text { Coeficients }\end{array}$} & \multirow{2}{*}{$\begin{array}{c}\begin{array}{c}\text { Standardized } \\
\text { Coefficients }\end{array} \\
\text { Beta }\end{array}$} & \multirow[b]{2}{*}{ 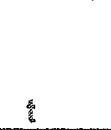 } & \multirow[b]{2}{*}{ Sig. } \\
\hline & & B & Std. Error & & & \\
\hline \multirow[t]{7}{*}{1} & (Constan') & 1.737 & 1.859 & & .935 & .352 \\
\hline & MOMEAN & .606 & .480 & .411 & 1.264 & .208 \\
\hline & MKMTMEAN & .344 & .565 & .297 & .609 & .543 \\
\hline & MKCPMEAN & -.199 & .099 & -.163 & -2.009 & .046 \\
\hline & MKTTMEAN & $-6.55 E-02$ & .087 & -.073 & -.750 & .454 \\
\hline & MKDMMEAN & .261 & .079 & .280 & 3.308 & .001 \\
\hline & MOMKMT &. .110 & .143 & -.437 & -.771 & .442 \\
\hline
\end{tabular}

a. Dependent Variable: performance $q 1$ 
Table 39. Regression using market turbulence multiplicative interaction term vs. performance against competitors

Model Summary

\begin{tabular}{|l|r|r|r|r|}
\hline Model & $R$ & R Square & $\begin{array}{c}\text { Adjusted } \\
\text { R Square }\end{array}$ & $\begin{array}{c}\text { Std. Error of } \\
\text { the Estimate }\end{array}$ \\
\hline 1 & $.399^{2}$ & .159 & .124 & .702 \\
\hline
\end{tabular}

a. Predictors: (Constant), MOMKMT, MKDMMEAN, MKCPMEAN, MKTTMEAN, MOMEAN, MKMTMEAN

ANOVA

\begin{tabular}{|ll|r|r|r|r|r|}
\hline Model & $\begin{array}{c}\text { Sum of } \\
\text { Squares }\end{array}$ & df & Mean Square & $F$ & Sig. \\
\hline 1 & Regression & 13.525 & 6 & 2.254 & 4.577 & $.000^{2}$ \\
& Residual & 71.416 & 145 & .493 & & \\
& Total & 84.941 & 151 & & & \\
\hline
\end{tabular}

a. Predictors: (Constant), MOMKMT, MKDMMEAN, MKCPMEAN, MKTTMEAN, MOMEA MKMTMEAN

b. Dependent Variable: performance $q 2$

Coefficients

\begin{tabular}{|c|c|c|c|c|c|c|}
\hline \multirow{2}{*}{\multicolumn{2}{|c|}{ Model }} & \multicolumn{2}{|c|}{$\begin{array}{l}\text { Unstandardized } \\
\text { Coefficients }\end{array}$} & \multirow{2}{*}{$\begin{array}{c}\text { Standardized } \\
\text { Coefficients }\end{array}$} & \multirow[b]{2}{*}{ 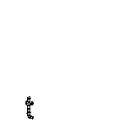 } & \multirow[b]{2}{*}{ Sig. } \\
\hline & & $\mathrm{B}$ & Std. Error & & & \\
\hline \multirow[t]{7}{*}{1} & (Constant) & 2.894 & 1.479 & & 1.956 & .052 \\
\hline & MOMEAN & .448 & .382 & .383 & 1.174 & .242 \\
\hline & MKMTMEAN & .235 & .450 & .255 & .523 & .602 \\
\hline & MKCPMEAN & -.211 & .079 & -.217 & -2.674 & .008 \\
\hline & MKTTMEAN & $-5.67 E-02$ & .069 & -.079 & -.816 & .416 \\
\hline & MKDMMEAN & .162 & .063 & .220 & 2.587 & .011 \\
\hline & MOMKMT & $-7.97 E-02$ & .114 & -.398 & -.700 & .485 \\
\hline
\end{tabular}

a. Dependent Variable: perfomance $q 2$ 
Table 40. Regression using market turbulence multiplicative interaction term vs. sales growth performance

Model Summary

\begin{tabular}{|l|r|r|r|r|}
\hline Model & R & R Square & $\begin{array}{c}\text { Adjusted } \\
\text { R Square }\end{array}$ & $\begin{array}{c}\text { Std. Error of } \\
\text { the Estimate }\end{array}$ \\
\hline 1 & $.505^{2}$ & .255 & .225 & .901 \\
\hline
\end{tabular}

a. Predictors: (Constant), MOMKMT, MKDMMEAN, MKCPMEAN, MKTTMEAN, MOMEAN, MKMTMEAN

ANOVA

\begin{tabular}{|c|c|c|c|c|c|c|}
\hline \multicolumn{2}{|c|}{ Model } & $\begin{array}{l}\text { Sum of } \\
\text { Squares }\end{array}$ & $d f$ & Mean Square & $F$ & Sig. \\
\hline \multirow[t]{3}{*}{1} & Regression & 40.390 & 6 & 6.732 & 8.292 & $.000^{\circ}$ \\
\hline & Residual & 117.709 & 145 & .812 & & \\
\hline & Total & 158.099 & 151 & & & \\
\hline
\end{tabular}

a. Predictors: (Constant), MOMKMT, MKDMMEAN, MKCPMEAN, MKTTMEAN, MOMEAI MKMTMEAN

b. Dependent Variable: performance $q 3$

Coeffieients ${ }^{2}$

\begin{tabular}{|c|c|c|c|c|c|c|}
\hline \multirow{2}{*}{\multicolumn{2}{|c|}{ Model }} & \multicolumn{2}{|c|}{$\begin{array}{c}\text { Unstandardized } \\
\text { Coefficients }\end{array}$} & \multirow{2}{*}{$\begin{array}{c}\begin{array}{c}\text { Standardized } \\
\text { Coefficients }\end{array} \\
\text { Beta }\end{array}$} & \multirow[b]{2}{*}{$t$} & \multirow[b]{2}{*}{ Sig. } \\
\hline & & 8 & Std. Error & & & \\
\hline \multirow[t]{7}{*}{1} & (Constant) & 2.353 & 1.899 & & 1.239 & .217 \\
\hline & MOMEAN & .283 & .490 & .177 & .578 & .564 \\
\hline & MKMTMEAN & -.107 & .577 & -.085 & -185 & .853 \\
\hline & MKCPMEAN & $-9.69 E-02$ & .101 & -.073 & -.958 & .340 \\
\hline & MKTTMEAN & $-9.12 E-02$ & .089 & -.094 & -1.023 & .308 \\
\hline & MKDMMEAN & .456 & .081 & .453 & 5.668 & .000 \\
\hline & MOMKMT & $-1.20 E-02$ & .146 &. .044 & -.082 & .935 \\
\hline
\end{tabular}

a. Dependent Variable: performance $\mathrm{q}^{3}$ 
Table 41. Regression using market turbulence multiplicative interaction term vs. market share growth

Model Sunmary

\begin{tabular}{|l|r|r|r|r|}
\hline Model & $R$ & R Square & $\begin{array}{l}\text { Adjusted } \\
\text { R Square }\end{array}$ & $\begin{array}{r}\text { Std. Error of } \\
\text { the Estimate }\end{array}$ \\
\hline 1 & $.490^{a}$ & .241 & .209 & .860 \\
\hline
\end{tabular}

a. Predictors: (Constant), MOMKMT, MKDMMEAN, MKCPMEAN, MKTTMEAN, MOMEAN, MKMTMEAN

ANOVA

\begin{tabular}{|c|c|c|c|c|c|c|}
\hline Model & & $\begin{array}{l}\text { Sum of } \\
\text { Squares }\end{array}$ & $d f$ & Mean Square & $F$ & Sig. \\
\hline \multirow[t]{3}{*}{1} & Regression & 33.927 & 6 & 5.654 & 7.654 & $.000^{2}$ \\
\hline & Residual & 107.126 & 145 & .739 & & \\
\hline & Total & 141.053 & 151 & & & \\
\hline
\end{tabular}

a. Predictors: (Constant), MOMKMT, MKDMMEAN, MKCPMEAN, MKTTMEAN, MOMEA MKMTMEAN

b. Dependent Variable: performance $\mathrm{q} 4$

Coefficients

\begin{tabular}{|c|c|c|c|c|c|c|}
\hline \multirow{2}{*}{\multicolumn{2}{|c|}{ Model }} & \multicolumn{2}{|c|}{$\begin{array}{c}\text { Unstandardized } \\
\text { Coeficients }\end{array}$} & \multirow{2}{*}{$\begin{array}{c}\text { Standardized } \\
\text { Coeficicients } \\
\text { Beta }\end{array}$} & \multirow[b]{2}{*}{$\downarrow$} & \multirow[b]{2}{*}{ Sig. } \\
\hline & & $\mathrm{B}$ & Std. Error & & & \\
\hline \multirow[t]{7}{*}{1} & (Constant) & 1.988 & 1.812 & & 1.097 & .274 \\
\hline & MOMEAN & .482 & .467 & .319 & 1.030 & .305 \\
\hline & MKMTMEAN & $3.701 E-02$ & .551 & .031 & .067 & .947 \\
\hline & MKCPMEAN & -.174 & .097 & -.139 & -1.804 & .073 \\
\hline & MKTTMEAN & $-3.72 E-02$ & .085 & -.040 & -.437 & .663 \\
\hline & MKOMMEAN & .343 & .077 & .361 & 4.462 & .000 \\
\hline & MOMKMT & $-5.39 E-02$ & .139 & -.209 & -.387 & .700 \\
\hline
\end{tabular}

a. Dependent Variable: performance 94 


\subsubsection{Competitive intensity multiplicative interaction term}

Table 42. Regression using competitive intensity multiplicative interaction term vs. performance relative to company objectives

Model Summary

\begin{tabular}{|l|r|r|r|r|}
\hline Model & $\mathrm{R}$ & $\mathrm{R}$ Square & $\begin{array}{c}\text { Adjusted } \\
\mathrm{R} \text { Square }\end{array}$ & $\begin{array}{c}\text { Std. Error of } \\
\text { the Estimate }\end{array}$ \\
\hline 1 & $.437^{2}$ & .191 & .158 & .867 \\
\hline
\end{tabular}

a. Predictors: (Constant), MOMKCP, MKDMMEAN, MKMTMEAN, MKTTMEAN, MOMEAN, MKCPMEAN

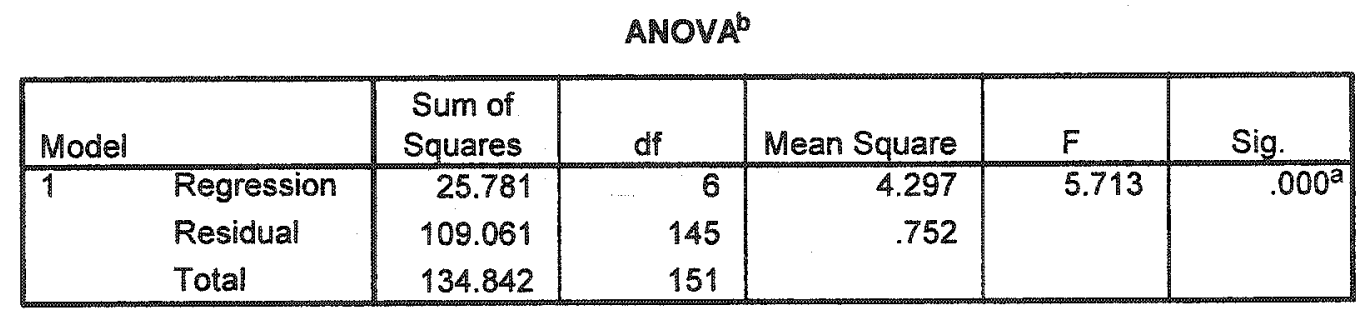

a. Predictors: (Constant), MOMKCP, MKDMMEAN, MKMTMEAN, MKTTMEAN, MOMEAI MKCPMEAN

b. Dependent Variable: performance $q 1$

Coefinients

\begin{tabular}{|c|c|c|c|c|c|c|}
\hline \multirow[b]{2}{*}{ Model } & & \multicolumn{2}{|c|}{$\begin{array}{l}\text { Unstandardized } \\
\text { Coefficients }\end{array}$} & \multirow{2}{*}{$\begin{array}{c}\text { Standardized } \\
\text { Coefficients } \\
\text { Beta }\end{array}$} & \multirow[b]{2}{*}{ 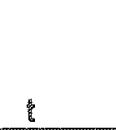 } & \multirow[b]{2}{*}{ Sig. } \\
\hline & & $B$ & Std. Error & & & \\
\hline \multirow[t]{7}{*}{1} & (Constant) & 7.045 & 1.784 & & 3.948 & .000 \\
\hline & MOMEAN & -.779 & .452 & -.528 & -1.724 & .087 \\
\hline & MKMTMEAN & $-9.96 E-02$ & .100 & -.086 & -.993 & .322 \\
\hline & MKCPMEAN & -1.480 & .545 & -1.194 & -2.681 & .008 \\
\hline & MKTTMEAN & $-2.99 E-02$ & .082 & -.033 & -.364 & .716 \\
\hline & MKDMMEAN & .232 & .078 & .250 & 2.994 & .003 \\
\hline & MOMKCP & .331 & .141 & 1.256 & 2.343 & .021 \\
\hline
\end{tabular}

a. Dependent Variable: performance $q 1$ 
Table 43. Regression using competitive intensity multiplicative interaction term vs. performance against competitors

\begin{tabular}{|c|c|c|c|c|}
\hline \multicolumn{5}{|c|}{ Model Summary } \\
\hline Model & $R$ & R Square & $\begin{array}{l}\text { Adjusted } \\
\text { R Square }\end{array}$ & $\begin{array}{l}\text { Std. Error of } \\
\text { the Estimate }\end{array}$ \\
\hline 1 & $.417^{a}$ & .174 & .140 & .696 \\
\hline
\end{tabular}

a. Predictors: (Constant), MOMKCP, MKDMMEAN, MKMTMEAN, MKTTMEAN, MOMEAN, MKCPMEAN

ANOVA

\begin{tabular}{|l|r|r|r|r|r|r|}
\hline Model & $\begin{array}{c}\text { Sum of } \\
\text { Squares }\end{array}$ & df & Mean Square & F & Sig. \\
\hline 1 & Regression & 14.781 & 6 & 2.463 & 5.091 & $.000^{2}$ \\
& Residual & 70.160 & 145 & .484 & & \\
Total & 84.941 & 151 & & & \\
\hline
\end{tabular}

a. Predictors: (Constant), MOMKCP, MKDMMEAN, MKMTMEAN, MKTTMEAN, MOMEA MKCPMEAN

b. Dependent Variable: performance $q 2$

Coofficients

\begin{tabular}{|c|c|c|c|c|c|c|}
\hline \multirow{2}{*}{\multicolumn{2}{|c|}{ Model }} & \multicolumn{2}{|c|}{$\begin{array}{c}\text { Unstandardized } \\
\text { Coefficients }\end{array}$} & \multirow{2}{*}{$\begin{array}{c}\begin{array}{c}\text { Standardized } \\
\text { Coefficients }\end{array} \\
\text { Beta }\end{array}$} & \multirow[b]{2}{*}{$t$} & \multirow[b]{2}{*}{ Sig. } \\
\hline & & $B$ & Std. Error & & & \\
\hline \multirow[t]{7}{*}{1} & (Constant) & 6.253 & 1.431 & & 4.369 & .000 \\
\hline & MOMEAN & .429 & .362 & -.366 & -1.184 & .238 \\
\hline & MKMTMEAN & $-8.35 E-02$ & .080 & -.091 & -1.038 & .301 \\
\hline & MKCPMEAN & -.971 & .437 & -1.000 & -2.222 & .028 \\
\hline & MKTTMEAN & $-3.29 E-02$ & .066 & -.046 & -.499 & .619 \\
\hline & MKDMMEAN & .144 & .062 & .196 & 2.320 & .022 \\
\hline & MOMKCP & .199 & .113 & .953 & 1.759 & .081 \\
\hline
\end{tabular}

a. Dependent Variable: pertormance $q 2$ 
Table 44. Regression using competitive intensity multiplicative interaction term vs. sales growth performance

\begin{tabular}{|l|r|r|r|r|}
\hline \multicolumn{3}{|c|}{ Model Summany } \\
\hline Model & $R$ & $R$ Square & $\begin{array}{c}\text { Adjusted } \\
\text { R Square }\end{array}$ & $\begin{array}{c}\text { Std. Error of } \\
\text { the Estimate }\end{array}$ \\
\hline 1 & $.529^{2}$ & .280 & .250 & .886 \\
\hline
\end{tabular}

a. Predictors: (Constant), MOMKCP, MKDMMEAN, MKMTMEAN, MKTTMEAN, MOMEAN, MKCPMEAN

ANOVA

\begin{tabular}{|ll|r|r|r|r|r|}
\hline Model & $\begin{array}{r}\text { Sum of } \\
\text { Squares }\end{array}$ & df & Mean Square & $F$ & Sig. \\
\hline 1 & Regression & 44.234 & 6 & 7.372 & 9.388 & $.000^{2}$ \\
& Residual & 113.864 & 145 & .785 & & \\
& Total & 158.099 & 151 & & \\
\hline
\end{tabular}

a. Predictors: (Constant), MOMKCP, MKDMMEAN, MKMTMEAN, MKTTMEAN, MOMEAI MKCPMEAN

b. Dependent Variable: performance $\mathrm{q} 3$

Coefficients

\begin{tabular}{|c|c|c|c|c|c|c|}
\hline \multirow{2}{*}{\multicolumn{2}{|c|}{ Model }} & \multicolumn{2}{|c|}{$\begin{array}{c}\text { Unstandardized } \\
\text { Coefficients }\end{array}$} & \multirow{2}{*}{$\begin{array}{c}\begin{array}{c}\text { Standardized } \\
\text { Coefficients }\end{array} \\
\text { Beta }\end{array}$} & \multirow[b]{2}{*}{$t$} & \multirow[b]{2}{*}{ Sig. } \\
\hline & & $B$ & Std. Error & & & \\
\hline \multirow[t]{7}{*}{1} & (Constant) & 6.316 & 1.823 & & 3.464 & .001 \\
\hline & MOMEAN & -.746 & .462 & -.467 & -1.617 & .108 \\
\hline & MKMTMEAN & -.168 & .102 & -.134 & -1.642 & .103 \\
\hline & MKCPMEAN & -1.310 & .557 & -.989 & -2.354 & .020 \\
\hline & MKTTMEAN & $-7.43 E-02$ & .084 & -.076 & -.885 & .378 \\
\hline & MKDMMEAN & .435 & .079 & .432 & 5.481 & .000 \\
\hline & MOMKCP & .319 & .144 & 1.121 & 2.214 & .028 \\
\hline
\end{tabular}

a. Dependent Variable: performence $q^{3}$ 
Table 45. Regression using competitive intensity multiplicative interaction term vs. market share growth

\begin{tabular}{|c|c|c|c|c|}
\hline \multicolumn{5}{|c|}{ Model Summary } \\
\hline Model & $R$ & R Square & $\begin{array}{l}\text { Adjusted } \\
\text { R Square }\end{array}$ & $\begin{array}{l}\text { Std. Error of } \\
\text { the Estimate }\end{array}$ \\
\hline 1 & $.501^{\mathrm{a}}$ & .251 & .220 & .854 \\
\hline
\end{tabular}

a. Predictors: (Constant), MOMKCP, MKDMMEAN, MKMTMEAN, MKTTMEAN, MOMEAN, MKCPMEAN

ANOYA

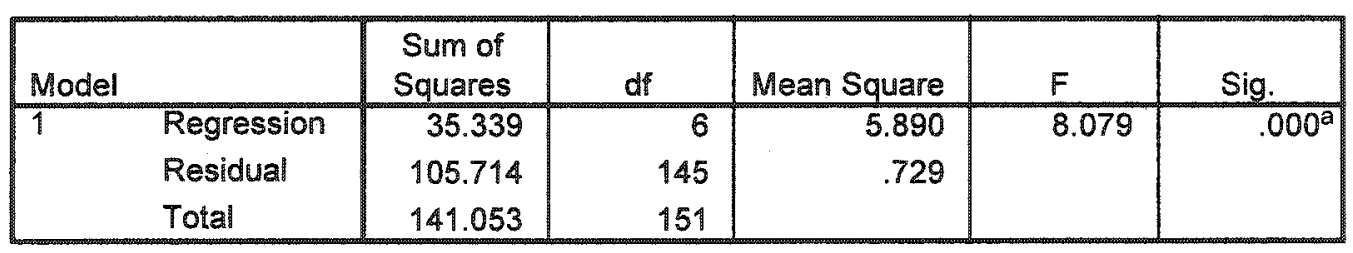

a. Predictors: (Constant), MOMKCP, MKDMMEAN, MKMTMEAN, MKTTMEAN, MOMEA MKCPMEAN

b. Dependent Variable: performance $q 4$

Coeficients

\begin{tabular}{|c|c|c|c|c|c|c|}
\hline \multirow{2}{*}{\multicolumn{2}{|c|}{ Model }} & \multicolumn{2}{|c|}{$\begin{array}{c}\text { Unstandardized } \\
\text { Coefficients }\end{array}$} & \multirow{2}{*}{$\begin{array}{c}\begin{array}{c}\text { Standardized } \\
\text { Coefficients }\end{array} \\
\text { Beta }\end{array}$} & \multirow[b]{2}{*}{$t$} & \multirow[b]{2}{*}{ Sig. } \\
\hline & & $\mathrm{B}$ & Std. Error & & & \\
\hline \multirow[t]{7}{*}{1} & (Constant) & 5.051 & 1.757 & & 2.875 & .005 \\
\hline & MOMEAN & -.317 & .445 & -210 & -.712 & .478 \\
\hline & MKMTMEAN & -.182 & .099 & -.153 & -1.840 & .068 \\
\hline & MKCPMEAN & -.940 & .536 & -.751 & -1.752 & .082 \\
\hline & MKTTMEAN & $-1.80 E-02$ & .081 & -.020 & -.222 & .824 \\
\hline & MKDMUEAN & .326 & .076 & .343 & 4.270 & .000 \\
\hline & MOMKCP & .201 & .139 & .746 & 1.445 & .151 \\
\hline
\end{tabular}

a. Dependent Variable: performance $q 4$ 


\subsubsection{Technological turbulence multiplicative interaction term}

Table 46. Regression using technological turbulence multiplicative interaction term vs. performance relative to company objectives

Model Summay

\begin{tabular}{|l|r|r|r|r|}
\hline Model & $R$ & R Square & $\begin{array}{c}\text { Adjusted } \\
\text { R Square }\end{array}$ & $\begin{array}{c}\text { Std. Error of } \\
\text { the Estimate }\end{array}$ \\
\hline 1 & $.401^{2}$ & .161 & .126 & .884 \\
\hline
\end{tabular}

a. Predictors: (Constant), MOMKTT, MKCPMEAN, MKMTMEAN, MKDMMEAN, MOMEAN, MKTTMEAN

\section{ANOVA}

\begin{tabular}{|ll|r|r|r|r|r|}
\hline Model & $\begin{array}{r}\text { Sum of: } \\
\text { Squares }\end{array}$ & df & Mean Square & F & Sig. \\
\hline 1 & Regression & 21.655 & 6 & 3.609 & 4.623 & $.000^{2}$ \\
& Residual & 113.187 & 145 & .781 & & \\
& Total & 134.842 & 151 & & \\
\end{tabular}

a. Predictors: (Constant), MOMKTT, MKCPMEAN, MKMTMEAN, MKDMMEAN, MOMEAI MKTTMEAN

b. Dependent Variable: performance $\mathrm{q} 1$

Cocticients

\begin{tabular}{|c|c|c|c|c|c|c|}
\hline \multirow{2}{*}{\multicolumn{2}{|c|}{ Model }} & \multicolumn{2}{|c|}{$\begin{array}{c}\text { Unstandardized } \\
\text { Coefficients }\end{array}$} & \multirow{2}{*}{$\begin{array}{l}\text { Standardized } \\
\text { Coeficienis } \\
\text { Beta }\end{array}$} & \multirow[b]{2}{*}{ 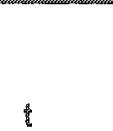 } & \multirow[b]{2}{*}{ Sig. } \\
\hline & & $B$ & Std. Error & & & \\
\hline \multirow[t]{7}{*}{1} & (Constant) & 3.157 & 1.542 & & 2.048 & .042 \\
\hline & MOMEAN & .230 & .409 & .156 & .562 & .575 \\
\hline & MKMTMEAN & $-8.34 E-02$ & .104 & -.072 & -.801 & .425 \\
\hline & MKCPMEAN & -.205 & .099 & -.167 & -2.067 & .041 \\
\hline & MKTTMEAN & $-6.27 E-02$ & .410 & -.070 &. .153 & .879 \\
\hline & MKDMMEAN & .254 & .078 & .273 & 3.237 & .001 \\
\hline & MOMKTT & $4.617 E-03$ & .106 & .024 & .044 & .965 \\
\hline
\end{tabular}

a. Dependent Variable: periomance $q$ ! 
Table 47. Regression using technological turbulence multiplicative interaction term vs. performance against the competition

Model Summary

\begin{tabular}{|l|r|r|r|r|}
\hline Model & $\mathrm{R}$ & $\mathrm{R}$ Square & $\begin{array}{c}\text { Adjusted } \\
\text { R Square }\end{array}$ & $\begin{array}{c}\text { Std. Error of } \\
\text { the Estimate }\end{array}$ \\
\hline 1 & $.396^{\mathrm{a}}$ & .157 & .122 & .703 \\
\hline
\end{tabular}

a. Predictors: (Constant), MOMKTT, MKCPMEAN, MKMTMEAN, MKDMMEAN, MOMEAN, MKTTMEAN

ANOVA

\begin{tabular}{|ll|r|r|r|r|r|}
\hline Model & $\begin{array}{c}\text { Sum of } \\
\text { Squares }\end{array}$ & df & Mean Square & $F$ & Sig. \\
\hline 1 & Regression & 13.302 & 6 & 2.217 & 4.487 & $.000^{2}$ \\
& Residual & 71.639 & 145 & .494 & & \\
& Total & 84.941 & 151 & & \\
\hline
\end{tabular}

a. Predictors: (Constant), MOMKTT, MKCPMEAN, MKMTMEAN, MKDMMEAN, MOMEA! MKTTMEAN

b. Dependent Variable: performance q2

Coemicients

\begin{tabular}{|c|c|c|c|c|c|c|}
\hline \multirow{2}{*}{\multicolumn{2}{|c|}{ Model }} & \multicolumn{2}{|c|}{$\begin{array}{c}\text { Unstandardized } \\
\text { Coefficients }\end{array}$} & \multirow{2}{*}{$\begin{array}{c}\begin{array}{c}\text { Standardized } \\
\text { Coefficients }\end{array} \\
\text { Beta }\end{array}$} & \multirow[b]{2}{*}{1} & \multirow[b]{2}{*}{ Sig. } \\
\hline & & 8 & Std. Error & & & \\
\hline \multirow[t]{7}{*}{1} & (Constant) & 4.092 & 1.227 & & 3.336 & .001 \\
\hline & MOMEAN & .129 & .325 & .110 & .396 & .693 \\
\hline & MKMTMEAN & $-7.10 E-02$ & .083 & -.077 & -.857 & .393 \\
\hline & MKCPMEAN & -.215 & .079 & -.222 & -2.733 & .007 \\
\hline & MKTTMEAN &. .104 & .326 & -.145 & -.317 & .751 \\
\hline & MKOMMEAN & .157 & .062 & .213 & 2.520 & .013 \\
\hline & MOMKTT & $1.621 E-02$ & .084 & .106 & .192 & .848 \\
\hline
\end{tabular}

a. Dependent Variable: performance $q 2$ 
Table 48. Regression using technological turbulence multiplicative interaction term vs. sales growth performance

Model Summary

\begin{tabular}{|l|r|r|r|r|}
\hline Model & \multicolumn{1}{|c|}{$R$} & R Square & $\begin{array}{c}\text { Adjusted } \\
\text { R Square }\end{array}$ & $\begin{array}{c}\text { Std. Error of } \\
\text { the Estimate }\end{array}$ \\
\hline 1 & $.506^{2}$ & .256 & .225 & .901 \\
\hline
\end{tabular}

a. Predictors: (Constant), MOMKTT, MKCPMEAN, MKMTMEAN, MKDMMEAN, MOMEAN, MKTTMEAN

ANOVA $^{b}$

\begin{tabular}{|ll|r|r|r|r|r|}
\hline \multicolumn{1}{|l|}{} & \multicolumn{1}{|c|}{$\begin{array}{c}\text { Sum of } \\
\text { Squares }\end{array}$} & df & Mean Square & F & Sig. \\
\hline 1 & Regression & 40.409 & 6 & 6.735 & 8.298 & $.000^{\circ}$ \\
& Residual & 117.690 & 145 & .812 & & \\
& Total & 158.099 & 151 & & & \\
\hline
\end{tabular}

a. Predictors: (Constant), MOMKTT, MKCPMEAN, MKMTMEAN, MKDMMEAN, MOMEA MKTTMEAN

b. Dependent Variable: performance $q^{3}$

Coefficients

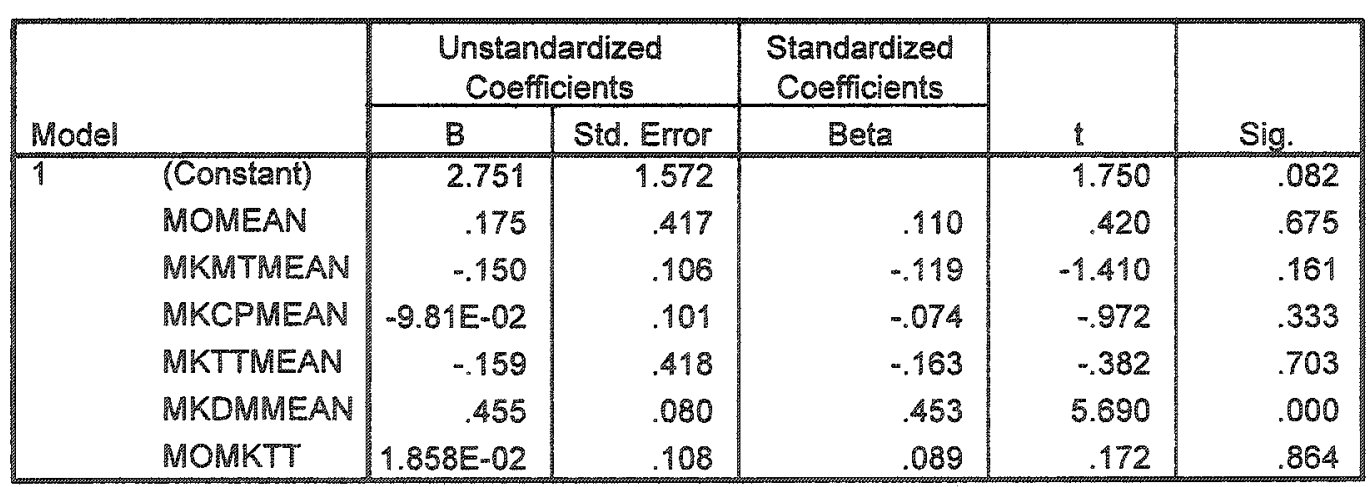

a. Dependent Variable: performance $q 3$ 
Table 49. Regression using technological turbulence multiplicative interaction term ys. market share growth

Model Summary

\begin{tabular}{|l|r|r|r|r|}
\hline Model & R & R Square & $\begin{array}{l}\text { Adjusted } \\
\text { R Square }\end{array}$ & $\begin{array}{l}\text { Std. Error of } \\
\text { the Estimate }\end{array}$ \\
\hline 1 & $.491^{2}$ & .241 & .210 & .859 \\
\hline
\end{tabular}

a. Predictors: (Constant), MOMKTT, MKCPMEAN, MKMTMEAN, MKDMMEAN, MOMEAN, MKTTMEAN

\section{ANOVA}

\begin{tabular}{|ll|r|r|r|r|r|}
\hline Model & \multicolumn{1}{|c|}{$\begin{array}{c}\text { Sum of } \\
\text { Squares }\end{array}$} & df & Mean Square & F & Sig. \\
\hline 1 & Regression & 34.061 & 6 & 5.677 & 7.694 & $.000^{2}$ \\
& Residual & 106.991 & 145 & .738 & & \\
& Total & 141.053 & 151 & & & \\
\hline
\end{tabular}

a. Predictors: (Constant), MOMKTT, MKCPMEAN, MKMTMEAN, MKDMMEAN, MOMEA MKTTMEAN

b. Dependent Variable: performance $q 4$

Coefficients $^{\mathrm{a}}$

\begin{tabular}{|c|c|c|c|c|c|c|}
\hline \multirow{2}{*}{\multicolumn{2}{|c|}{ Model }} & \multicolumn{2}{|c|}{$\begin{array}{c}\text { Unstandardized } \\
\text { Coefficients }\end{array}$} & \multirow{2}{*}{$\begin{array}{c}\begin{array}{c}\text { Standardized } \\
\text { Coefficients }\end{array} \\
\text { Beta }\end{array}$} & \multirow[b]{2}{*}{$t$} & \multirow[b]{2}{*}{ Sig. } \\
\hline & & $\mathrm{B}$ & Std. Error & & & \\
\hline \multirow[t]{7}{*}{1} & (Constant) & 1.855 & 1.499 & & 1.237 & .218 \\
\hline & MOMEAN & .526 & .397 & .348 & 1.324 & .188 \\
\hline & MKMTMEAN & -.184 & .101 & -.155 & -1.821 & .071 \\
\hline & MKCPMEAN & -.175 & .096 & -140 & -1.816 & .071 \\
\hline & MKTTMEAN & .197 & .398 & .214 & .496 & .621 \\
\hline & MKDMMEAN & .340 & .076 & .358 & 4.455 & .000 \\
\hline & MOMKTT & $-5.93 E-02$ & .103 & -.301 & -.576 & .565 \\
\hline
\end{tabular}

a. Dependent Variable: performance gh 


\subsubsection{Demand multiplicative interaction term}

Table 50. Regression using demand multiplicative interaction term vs. performance relative to company objectives

Model Summary

\begin{tabular}{|l|r|r|r|r|}
\hline Model & $R$ & R Square & $\begin{array}{c}\text { Adjusted } \\
\text { R Square }\end{array}$ & $\begin{array}{c}\text { Std. Error of } \\
\text { the Estimate }\end{array}$ \\
\hline 1 & $.418^{2}$ & .174 & .140 & .876 \\
\hline
\end{tabular}

a. Predictors: (Constant), MOMKDM, MKMTMEAN, MKCPMEAN, MOMEAN, MKTTMEAN, MKDMMEAN

ANOVA

\begin{tabular}{|ll|r|r|r|r|r|}
\hline Model & $\begin{array}{c}\text { Sum of } \\
\text { Squares }\end{array}$ & df & Mean Square & F & Sig. \\
\hline 1 & Regression & 23.515 & 6 & 3.919 & 5.105 & $.000^{a}$ \\
& Residual & 111.327 & 145 & .768 & & \\
& Total & 134.842 & 151 & & & \\
\hline
\end{tabular}

a. Predictors: (Constant), MOMKDM, MKMTMEAN, MKCPMEAN, MOMEAN, MKTTMEAI MKDMMEAN

b. Dependent Variable: performance q1

Coefficients $^{2}$

\begin{tabular}{|c|c|c|c|c|c|c|}
\hline \multirow{2}{*}{\multicolumn{2}{|c|}{ Model }} & \multicolumn{2}{|c|}{$\begin{array}{c}\text { Unstandardized } \\
\text { Coefficients }\end{array}$} & \multirow{2}{*}{$\begin{array}{c}\text { Standardized } \\
\text { Coefficients }\end{array}$} & \multirow[b]{2}{*}{1} & \multirow[b]{2}{*}{ Sig. } \\
\hline & & 8 & Std. Error & & & \\
\hline \multirow[t]{7}{*}{1} & (Constart) & 1.284 & 1.304 & & .984 & .327 \\
\hline & MOMEAN & .724 & .327 & .491 & 2.216 & .028 \\
\hline & MKMTMEAN & $-8.39 E-02$ & .101 & -.072 & -.830 & .408 \\
\hline & MKCPMEAN & -.192 & .098 & -.157 & -1.952 & .053 \\
\hline & MKTTMEAN & $-5.01 E-02$ & .083 & -.056 & -.606 & .546 \\
\hline & MKDMMEAN & .823 & .374 & .886 & 2.203 & .029 \\
\hline & MOMKDM & -.151 & .097 & -.724 & -1.557 & .122 \\
\hline
\end{tabular}

a. Dependent Variable: pertomance q1 
Table 51. Regression using demand multiplicative interaction term vs. performance against the competition

Model Summary

\begin{tabular}{|l|r|r|r|r|}
\hline Model & $R$ & $R$ Square & $\begin{array}{c}\text { Adjusted } \\
\text { R Square }\end{array}$ & $\begin{array}{c}\text { Std. Error of } \\
\text { the Estimate }\end{array}$ \\
\hline 1 & $.435^{\circ}$ & .190 & .156 & .689 \\
\hline
\end{tabular}

a. Predictors: (Constant), MOMKDM, MKMTMEAN, MKCPMEAN, MOMEAN, MKTTMEAN, MKDMMEAN

ANOVA

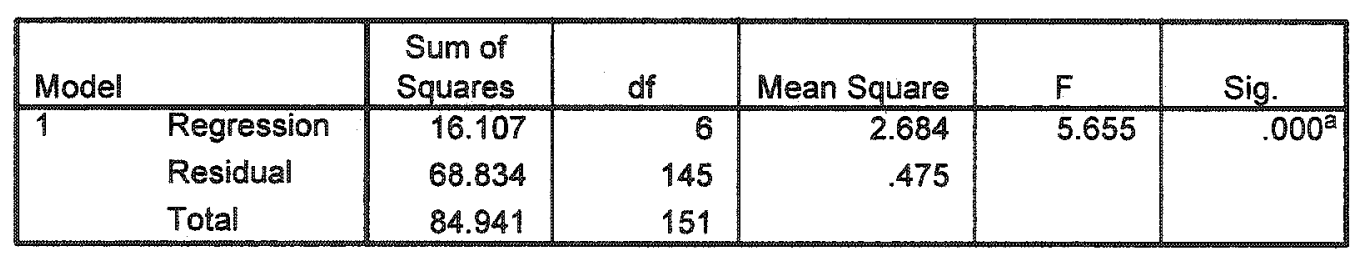

a. Predictors: (Constant), MOMKDM, MKMTMEAN, MKCPMEAN, MOMEAN, MKTTMEA MKDMMEAN

b. Dependent Variable: performance $q 2$

Coefficients ${ }^{\mathrm{a}}$

\begin{tabular}{|c|c|c|c|c|c|c|}
\hline \multirow{2}{*}{\multicolumn{2}{|c|}{ Model }} & \multicolumn{2}{|c|}{$\begin{array}{l}\text { Unstandardized } \\
\text { Coefficients }\end{array}$} & \multirow{2}{*}{$\begin{array}{c}\begin{array}{c}\text { Standardized } \\
\text { Coefficients }\end{array} \\
\text { Beta }\end{array}$} & \multirow[b]{2}{*}{1} & \multirow[b]{2}{*}{ Sig. } \\
\hline & & B & Std. Error & & & \\
\hline \multirow[t]{7}{*}{1} & (Constant) & 1.644 & 1.026 & & 1.603 & .111 \\
\hline & MOMEAN & .776 & .257 & .663 & 3.022 & .003 \\
\hline & MKMTMEAN & $-7.37 E-02$ & .080 & -.080 & -.927 & .355 \\
\hline & MKCPMEAN & -.200 & .077 & -.206 & -2.578 & .011 \\
\hline & MKTTMEAN & $-4.82 E-02$ & .065 & -.067 & -.740 & .460 \\
\hline & MKDMMEAN & .858 & .294 & 1.164 & 2.921 & .004 \\
\hline & MOMKDM & -.186 & .076 & -1.124 & -2.439 & .016 \\
\hline
\end{tabular}

a. Dependent Variable: perfomance $q 2$ 
Table 52. Regression using demand multiplicative interaction term vs. sales growth performance

Model Summary

\begin{tabular}{|l|r|r|r|r|}
\hline Model & \multicolumn{1}{|c|}{$\mathrm{R}$} & $\mathrm{R}$ Square & $\begin{array}{r}\text { Adjusted } \\
\text { R Square }\end{array}$ & $\begin{array}{r}\text { Std. Error of } \\
\text { the Estimate }\end{array}$ \\
\hline 1 & $.510^{2}$ & .261 & .230 & .898 \\
\hline
\end{tabular}

a. Predictors: (Constant), MOMKDM, MKMTMEAN, MKCPMEAN, MOMEAN, MKTTMEAN, MKDMMEAN

ANOVA

\begin{tabular}{|ll|r|r|r|r|r|}
\hline Model & & $\begin{array}{r}\text { Sum of } \\
\text { Squares }\end{array}$ & \multicolumn{1}{c|}{$\mathrm{df}$} & Mean Square & F & Sig. \\
\hline 1 & Regression & 41.188 & 6 & 6.865 & 8.514 & $.000^{2}$ \\
& Residual & 116.911 & 145 & .806 & & \\
& Total & 158.099 & 151 & & & \\
\hline
\end{tabular}

a. Predictors: (Constant), MOMKDM, MKMTMEAN, MKCPMEAN, MOMEAN, MKTTMEA MKDMMEAN

b. Dependent Variable: performance $q^{3}$

Coefficients $^{2}$

\begin{tabular}{|c|c|c|c|c|c|c|}
\hline \multirow{2}{*}{\multicolumn{2}{|c|}{ Model }} & \multicolumn{2}{|c|}{$\begin{array}{c}\text { Unstandardized } \\
\text { Coefficients }\end{array}$} & \multirow{2}{*}{$\begin{array}{c}\begin{array}{c}\text { Standardized } \\
\text { Coefficients }\end{array} \\
\text { Beta }\end{array}$} & \multirow[b]{2}{*}{1} & \multirow[b]{2}{*}{ Sig. } \\
\hline & & B & Std. Error & & & \\
\hline \multirow[t]{7}{*}{1} & (Constant) & 1.311 & 1.337 & & .981 & .328 \\
\hline & MOMEAN & .558 & .335 & .349 & 1.665 & .098 \\
\hline & MKMTMEAN & -.153 & .104 & -.122 & -1.479 & .141 \\
\hline & MKCPMEAN & $-8.94 \mathrm{E}-02$ & .101 & -.068 & -.886 & .377 \\
\hline & MKTTMEAN & $-9.23 E-02$ & .085 & -.095 & -1.088 & .278 \\
\hline & MKDMMEAN & .829 & .383 & .824 & 2.166 & .032 \\
\hline & MOMKDM & $-9.92 E-02$ & .099 & -.439 & -.998 & .320 \\
\hline
\end{tabular}

a. Dependent Variable: performance q3 
Table 53. Regression using demand multiplicative interaction term vs. market share growth

Model Summary

\begin{tabular}{|l|r|r|r|r|}
\hline Model & R & R Square & $\begin{array}{c}\text { Adjusted } \\
\text { R Square }\end{array}$ & $\begin{array}{c}\text { Std. Error of } \\
\text { the Estimate }\end{array}$ \\
\hline 1 & $.515^{\mathrm{a}}$ & .265 & .234 & .846 \\
\hline
\end{tabular}

a. Predictors: (Constant), MOMKDM, MKMTMEAN, MKCPMEAN, MOMEAN, MKTTMEAN, MKDMMEAN

\section{ANOVA}

\begin{tabular}{|ll|r|r|r|r|r|}
\hline Model & $\begin{array}{r}\text { Sum of } \\
\text { Squares }\end{array}$ & df & Mean Square & F & Sig. \\
\hline 1 & Regression & 37.358 & 6 & 6.226 & 8.707 & $.000^{2}$ \\
Residual & 103.695 & 145 & .715 & & \\
Total & 141.053 & 151 & & \\
\hline
\end{tabular}

a. Predictors: (Constant), MOMKDM, MKMTMEAN, MKCPMEAN, MOMEAN, MKTTMEAI MKDMMEAN

b. Dependent Variable: performance $q 4$

Coefficients

\begin{tabular}{|c|c|c|c|c|c|c|}
\hline \multirow{2}{*}{\multicolumn{2}{|c|}{ Model }} & \multicolumn{2}{|c|}{$\begin{array}{c}\text { Unstandardized } \\
\text { Coefficients }\end{array}$} & \multirow{2}{*}{$\begin{array}{c}\begin{array}{c}\text { Standardized } \\
\text { Coefficients }\end{array} \\
\text { Beta }\end{array}$} & \multirow[b]{2}{*}{ t } & \multirow[b]{2}{*}{ Sig. } \\
\hline & & B & Std. Error & & & \\
\hline \multirow[t]{7}{*}{1} & (Constant) & .154 & 1.259 & & .122 & .903 \\
\hline & MOMEAN & .964 & .315 & .639 & 3.059 & .003 \\
\hline & MKMTMEAN & -.172 & .098 & -.145 & -1.761 & .080 \\
\hline & MKCPMEAN & -.160 & .095 & -.128 & -1.683 & .095 \\
\hline & MKTTMEAN & $-3.41 E-02$ & .080 & -.037 & -.427 & .670 \\
\hline & MKDMMEAN & 1.125 & .361 & 1.183 & 3.118 & .002 \\
\hline & MOMKDM & -.208 & .094 & -.977 & -2.225 & .028 \\
\hline
\end{tabular}

a. Dependent Variable: performance 94 


\subsection{Manufacturing vs. telecommunication: t tests}

Table 54. $t$ tests between manufacturing and telecommunication, with respect to other variables

\begin{tabular}{|c|c|c|c|c|c|}
\hline 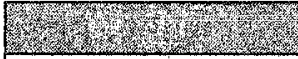 & (28) & Morins & $\sqrt{6}$ & 12) & Sig, ( $1 \mathrm{kinfed})$ \\
\hline \multirow{2}{*}{ perfa } & manufacturing & 3.70 & .92 & \multirow{2}{*}{23} & \multirow{2}{*}{.82} \\
\hline & telecommunications & 3.67 & .98 & & \\
\hline \multirow{2}{*}{ perfo2 } & manufacturing & 3.95 & 76 & \multirow{2}{*}{.54} & \multirow{2}{*}{.59} \\
\hline & telecommunications & 4.01 & 74 & & \\
\hline \multirow{2}{*}{ perfq3 } & manufacturing & 3.64 & 1.01 & \multirow{2}{*}{-30} & \multirow{2}{*}{.77} \\
\hline & telecommunications & 3.59 & 1.04 & & \\
\hline \multirow{2}{*}{ perfq4 } & manufacturing & 3.55 & 1.11 & \multirow{2}{*}{-.43} & \multirow{2}{*}{67} \\
\hline & telecommunications & 3.61 & .80 & & \\
\hline \multirow{2}{*}{ philosophy q1 } & manufacturing & 4.03 & 1.14 & \multirow{2}{*}{.62} & \multirow{2}{*}{.53} \\
\hline & telecommunications & 4.13 & .98 & & \\
\hline \multirow{2}{*}{ philosophy q2 } & manufacturing & 3.71 & 1.16 & \multirow{2}{*}{-1.17} & \multirow{2}{*}{.24} \\
\hline & telecommunications & 3.92 & 1.0 & & \\
\hline \multirow{2}{*}{ philosophy q3 } & manufacturing & 4.60 & .59 & \multirow{2}{*}{-74} & \multirow{2}{*}{.46} \\
\hline & telecommunications & 4.52 & 70 & & \\
\hline \multirow{2}{*}{1 st or 2nd Round } & manufacturing & 1.52 & 50 & \multirow{2}{*}{-1.99} & \multirow{2}{*}{1.05} \\
\hline & telecommunications & 1.36 & .48 & & \\
\hline \multirow{2}{*}{ MOMEAN } & manufacturing & 3.78 & 63 & \multirow{2}{*}{14} & \multirow{2}{*}{.89} \\
\hline & telecommunications & 3.76 & 66 & & \\
\hline \multirow{2}{*}{ MKMTMEAN } & manufacturing & 3.09 & 82 & \multirow{2}{*}{-1.09} & 28 \\
\hline & telecommunications & 3.23 & 81 & & $1<0$ \\
\hline MKCPMEAN & manufacturing & 3.21 & 80 & 1456 & 12 \\
\hline & telecommunications & 3.02 & 73 & & \\
\hline MKTTMFAN & manufacturing & 3.37 & 1.08 & $1-237$ & 109 \\
\hline WR M WWEAM & telecommunications & 3.76 & 98 & Fastif & $.0<$ \\
\hline MKDMMMAMNAM & manufacturing & 2.64 & 91 & -2.62 & 1.01 \\
\hline 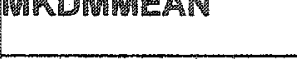 & telecommunications & 3.06 & 1.08 & +2.02 & 1.01 \\
\hline PERFMEAN & manufacturing & 3.71 & 80 & -10 & 92 \\
\hline & telecommunications & 3.72 & 74 & & \\
\hline Hemolovees & manufacturing & 103 & 150.16 & 07 & 194 \\
\hline tromprosos & telecommunications & 101 & 159.82 & ( & \\
\hline Annualoglos & manufacturing & 21.50 & 39.39 & 106 & 20 \\
\hline Amuar sales & telecommunications & 15.53 & 24.15 & T.00 & $<\infty$ \\
\hline ect? & manufacturing & 1974 & 20.94 & 71 & 148 \\
\hline 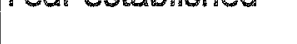 & telecommunications & 1976 & 22.37 & & \\
\hline
\end{tabular}


1.8 Manufacturing vs. telecommunications: regressions

Table 55. Regression of model 1 , telecommunications companies only

Model Summary

\begin{tabular}{|l|r|r|r|r|}
\hline \multicolumn{1}{|c|}{$R$} & & & \\
\cline { 1 - 4 } & $\begin{array}{c}\text { Telecom or } \\
\text { manufacturing } \\
\text { Modelecom } \\
\text { (Selected) }\end{array}$ & R Square & $\begin{array}{c}\text { Adjusted } \\
\text { R Square }\end{array}$ & $\begin{array}{c}\text { Std. Error of } \\
\text { the Estimate }\end{array}$ \\
\hline 1 & $.231^{2}$ & .053 & .040 & .72355 \\
\hline
\end{tabular}

a. Predictors: (Constant), MOMEAN

ANOVA ${ }^{b, c}$

\begin{tabular}{|c|c|c|c|c|c|c|}
\hline Model & & $\begin{array}{l}\text { Sum of } \\
\text { Squares }\end{array}$ & $d f$ & Mean Square & $F$ & Sig. \\
\hline \multirow[t]{3}{*}{1} & Regression & 2.152 & 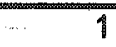 & 2.152 & 4.111 & $.046^{a}$ \\
\hline & Residual & 38.218 & 73 & .524 & & \\
\hline & Total & 40.370 & 74 & & & \\
\hline
\end{tabular}

a. Predictors: (Constant), MOMEAN

b. Dependent Variable: PERFMEAN

c. Selecting only cases for which Telecom or manufacturing $=$ telecom

Coefficients,

\begin{tabular}{|c|c|c|c|c|c|}
\hline \multirow[b]{2}{*}{ Model } & \multicolumn{2}{|c|}{$\begin{array}{c}\text { Unstandardized } \\
\text { Coefficients }\end{array}$} & \multirow{2}{*}{$\begin{array}{c}\begin{array}{c}\text { Standardized } \\
\text { Coefficients }\end{array} \\
\text { Beta }\end{array}$} & \multirow[b]{2}{*}{ t: } & \multirow[b]{2}{*}{ Sig. } \\
\hline & $\mathrm{B}$ & Sid. Error & & & \\
\hline (Constan') & 2.744 & .488 & & 5.618 & .000 \\
\hline MOMEAN & .259 & .128 & .231 & 2.028 & .046 \\
\hline
\end{tabular}

a. Dependent Variable: PERFMEAN

b. Selecting only cases for which Telecom or manuracturing = telecom 
Table 56. Regression of model 1, manufacturing companies only

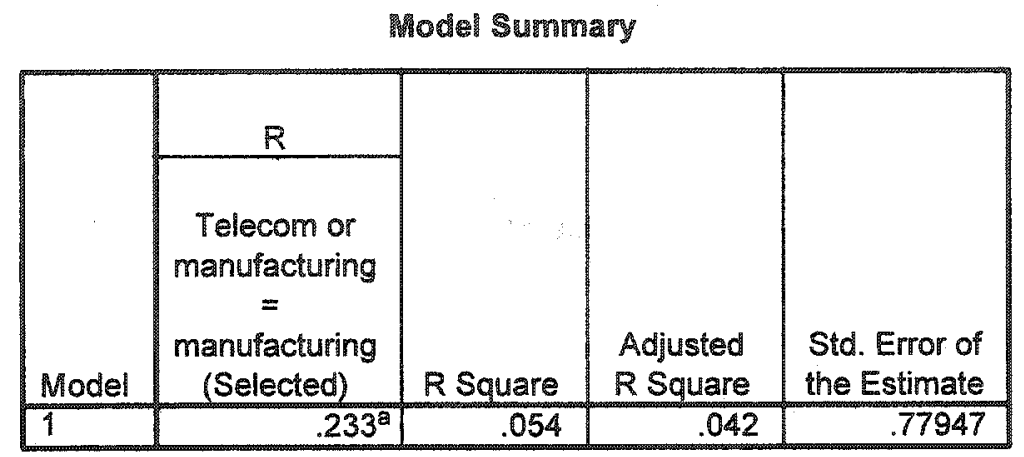

a. Predictors: (Constant), MOMEAN

ANOVA ${ }^{b, c}$

\begin{tabular}{|ll|r|r|r|r|r|}
\hline Model & $\begin{array}{c}\text { Sum of } \\
\text { Squares }\end{array}$ & df & Mean Square & $F$ & Sig. \\
\hline 1 & Regression & 2.607 & 1 & 2.607 & 4.291 & $.042^{2}$ \\
& Residual & 45.568 & 75 & .608 & & \\
& Total & 48.175 & 76 & & & \\
\hline
\end{tabular}

a. Predictors: (Constant), MOMEAN

b. Dependent Variable: PERFMEAN

c. Selecting only cases for which Telecom or manufacturing = manufacturing

Coefficients,

\begin{tabular}{|c|c|c|c|c|c|c|}
\hline \multirow{2}{*}{\multicolumn{2}{|c|}{ Model }} & \multicolumn{2}{|c|}{$\begin{array}{l}\text { Unstandardized } \\
\text { Coefficients }\end{array}$} & \multirow{2}{*}{$\begin{array}{c}\begin{array}{c}\text { Standardized } \\
\text { Coefficients }\end{array} \\
\text { Beta }\end{array}$} & \multirow[b]{2}{*}{ t } & \multirow[b]{2}{*}{ Sig. } \\
\hline & & 8 & Std. Error & & & \\
\hline & (Constant) & 2.593 & .546 & & 4.752 & .000 \\
\hline & MOMEAN & .295 & .142 & .233 & 2.072 & .042 \\
\hline
\end{tabular}

a. Dependent Variable: PERFMEAN

b. Selecting only cases for which Telecom or manufacturing $=$ manutacturing 
Table 57. Regression of model 2 , telecommunications companies only

model Summary

\begin{tabular}{|c|c|c|c|c|}
\hline & $R$ & & & \\
\hline Model & $\begin{array}{l}\text { Telecom or } \\
\text { manufacturing } \\
=\text { selecom } \\
\text { (Selected) }\end{array}$ & R Square & $\begin{array}{l}\text { Adjusted } \\
\text { R Square }\end{array}$ & $\begin{array}{l}\text { Std. Error of } \\
\text { the Estimate }\end{array}$ \\
\hline 1 & $.605^{a}$ & .366 & .320 & .60912 \\
\hline
\end{tabular}

a. Predictors: (Constant), MKDMMEAN, MOMEAN, MKMTMEAN, MKCPMEAN, MKTTMEAN

ANOVA ${ }^{b, c}$

\begin{tabular}{|ll|r|r|r|r|r|}
\hline Model & $\begin{array}{c}\text { Sum of } \\
\text { Squares }\end{array}$ & df & Mean Square & F & Sig. \\
\hline 1 & Regression & 14.769 & 5 & 2.954 & 7.961 & $.000^{2}$ \\
& Residual & 25.601 & 69 & .371 & & \\
& Total & 40.370 & 74 & & \\
\hline
\end{tabular}

a. Predictors: (Constant), MKDMMEAN, MOMEAN, MKMTMEAN, MKCPMEAN, MKTTMEAN

b. Dependent Variable: PERFMEAN

c. Selecting only cases for which Telecom or manufacturing $=$ telecom

Coefficients s, $^{2, b}$

\begin{tabular}{|c|c|c|c|c|c|c|}
\hline \multirow{2}{*}{\multicolumn{2}{|c|}{ Model }} & \multicolumn{2}{|c|}{$\begin{array}{c}\text { Unstandardized } \\
\text { Coefficients }\end{array}$} & \multirow{2}{*}{$\begin{array}{c}\text { Standardized } \\
\text { Coefficients }\end{array}$} & \multirow[b]{2}{*}{$t$} & \multirow[b]{2}{*}{ Sig. } \\
\hline & & $\mathrm{B}$ & Std. Error & & & \\
\hline \multirow[t]{6}{*}{1} & (Constani) & 2.942 & .626 & & 4.702 & .000 \\
\hline & MOMEAN & .250 & .108 & .222 & 2.305 & .024 \\
\hline & MKMTMEAN & -.179 & .098 & -.196 & -1.821 & .073 \\
\hline & MKCPMEAN & -.129 & .100 & -.127 & -1.281 & 205 \\
\hline & MKTTMEAN & $-6.99 E-02$ & .084 & -.093 & -.835 & .407 \\
\hline & MKDMMEAN & .348 & .071 & .511 & 4.939 & .000 \\
\hline
\end{tabular}

a. Dependent Variable: PERFMEAN

b. Selecting only cases for which Telecom or manufacturing = telecom 
Table 58. Regression of model 2, manufacturing companies only

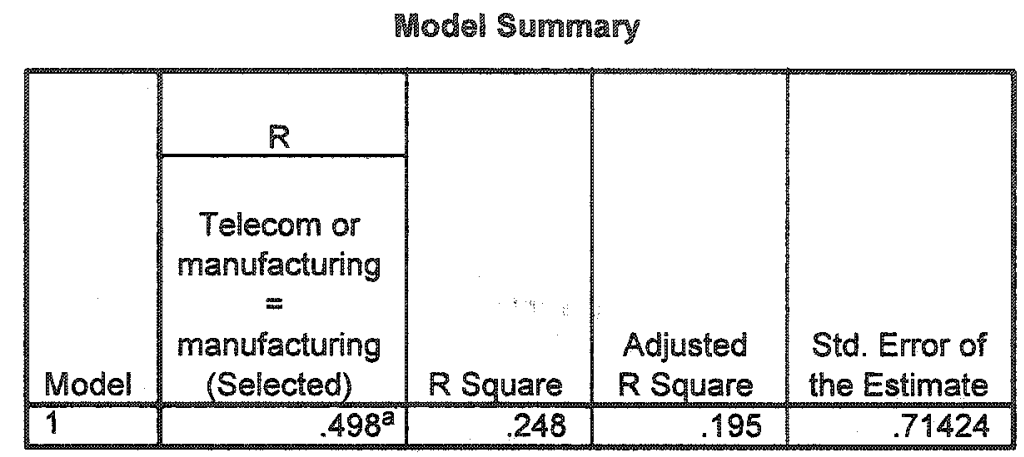

a. Predictors: (Constant), MKDMMEAN, MKMTMEAN, MOMEAN, MKCPMEAN, MKTTMEAN

ANOVA,c

\begin{tabular}{|c|c|c|c|c|c|c|}
\hline Model & & $\begin{array}{l}\text { Sum of } \\
\text { Squares }\end{array}$ & $d f$ & Mean Square & $F$ & Sig. \\
\hline \multirow[t]{3}{*}{1} & Regression & 11.955 & 5 & 2.391 & 4.687 & $.001^{2}$ \\
\hline & Residual & 36.220 & 71 & .510 & & \\
\hline & Total & 48.175 & 76 & & & \\
\hline
\end{tabular}

a. Predictors: (Constant), MKDMMEAN, MKMTMEAN, MOMEAN, MKCPMEAN, MKTTMEAN

b. Dependent Variable: PERFMEAN

c. Selecting only cases for which Telecom or manufacturing = manufacturing

Coefficients, ${ }^{\mathrm{a}, \mathrm{b}}$

\begin{tabular}{|c|c|c|c|c|c|c|}
\hline \multirow{2}{*}{\multicolumn{2}{|c|}{ Model }} & \multicolumn{2}{|c|}{$\begin{array}{l}\text { Unstandardized } \\
\text { Coefficients }\end{array}$} & \multirow{2}{*}{$\begin{array}{c}\begin{array}{c}\text { Standardized } \\
\text { Coefficients }\end{array} \\
\text { Beta }\end{array}$} & \multirow[b]{2}{*}{8} & \multirow[b]{2}{*}{ Sig. } \\
\hline & & 8 & Std. Error & & & \\
\hline \multirow[t]{6}{*}{1} & (Constant) & 3.072 & $\ldots .669$ & & 4.592 & .000 \\
\hline & MONEAN & .263 & .139 & .207 & 1.889 & .063 \\
\hline & MKMTMEAN & $-4.96 E-02$ & .122 & -.051 & -.408 & .685 \\
\hline & MKCPMEAN & -.262 & .115 & -.265 & -2.272 & .026 \\
\hline & MKTTMEAN & $-9.74 E-03$ & .097 & -.013 & -.100 & .921 \\
\hline & MKDMMEAN & .254 & .101 & .289 & 2.504 & .015 \\
\hline
\end{tabular}

a. Dependent Variable: PERFMEAN

b. Selecting only cases for which Telecom or manufacturing = manufacturing 
Table 59. Model 3, Regression with market turbulence multiplicative term for telecommunications companies only

Model Summary

\begin{tabular}{|c|c|c|c|c|}
\hline & $\mathbb{R}$ & & & \\
\hline Model & $\begin{array}{l}\text { Telecom or } \\
\text { manufacturing } \\
=\text { telecom } \\
\text { (Selected) }\end{array}$ & R Square & $\begin{array}{l}\text { Adjusted } \\
\text { R Square }\end{array}$ & $\begin{array}{l}\text { Std. Error of } \\
\text { the Estimate }\end{array}$ \\
\hline 1 & $.611^{\mathrm{a}}$ & .374 & .319 & .60968 \\
\hline
\end{tabular}

a. Predictors: (Constant), MOMKMT, MKCPMEAN. MKDMMEAN, MKTTMEAN, MOMEAN, MKMTMEAN

\section{ANONA ${ }^{b, c}$}

\begin{tabular}{|ll|r|r|r|r|r|}
\hline Model & $\begin{array}{c}\text { Sum of } \\
\text { Squares }\end{array}$ & df & Mean Square & $F$ & Sig. \\
\hline 1 & Regression & 15.094 & 6 & 2.516 & 6.768 & $.000^{2}$ \\
& Residual & 25.276 & 68 & .372 & & \\
& Total & 40.370 & 74 & & \\
\hline
\end{tabular}

a. Predictors: (Constant), MOMKMT, MKCPMEAN, MKDMMEAN, MKTTMEAN, MOMEA MKMTMEAN

b. Dependent Variable: PERFMEAN

c. Selecting only cases for which Telecom or manufacturing = telecom

\section{Coeficionts, $b$}

\begin{tabular}{|c|c|c|c|c|c|c|}
\hline \multirow{2}{*}{\multicolumn{2}{|c|}{ Model }} & \multicolumn{2}{|c|}{$\begin{array}{c}\text { Unstandardized } \\
\text { Coefficients }\end{array}$} & \multirow{2}{*}{$\begin{array}{c}\text { Standardized } \\
\text { Coefficients }\end{array}$} & \multirow[b]{2}{*}{ 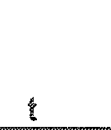 } & \multirow[b]{2}{*}{ Sig. } \\
\hline & & $B$ & Std. Error & & & \\
\hline \multirow[t]{7}{*}{1} & (Constant) & 1.318 & 1.848 & & .713 & .478 \\
\hline & MOMEAN & .694 & .488 & .618 & 1.423 & .159 \\
\hline & MKMTMEAN & .343 & .567 & .377 & .605 & .547 \\
\hline & MKCPMEAN & -.135 & .101 & -.134 & -1.340 & .185 \\
\hline & MKTTMEAN & $-9.35 E-02$ & .088 & -.125 & -1.068 & .290 \\
\hline & MKDMMEAN & .363 & .072 & .532 & 5.021 & .000 \\
\hline & MOMKMT & -.137 & .147 & -.714 & -.934 & .353 \\
\hline
\end{tabular}

a. Dependen Variable: PERFMEAN

b. Selecting only cases for which Telecom or manufacturing = telecom 
Table 60. Model 3, Regression with market turbulence multiplicatiuve term for manufacturing companies only

Wodel Summary

\begin{tabular}{|c|c|c|c|c|}
\hline & $R$ & & & \\
\hline Model & $\begin{array}{c}\text { Telecom or } \\
\text { manufacturing } \\
= \\
\text { manufacturing } \\
\text { (Selected) }\end{array}$ & R Square & $\begin{array}{l}\text { Adjusted } \\
\text { R Square }\end{array}$ & $\begin{array}{l}\text { Std. Error of } \\
\text { the Estimate }\end{array}$ \\
\hline 1 & $.498^{a}$ & .248 & .184 & .71928 \\
\hline
\end{tabular}

a. Predictors: (Constant), MOMKMT, MKDMMEAN, MKCPMEAN, MOMEAN, MKTTMEAN, MKMTMEAN

\section{ANOVA $^{b, c}$}

\begin{tabular}{|c|c|c|c|c|c|c|}
\hline Model & & $\begin{array}{l}\text { Sum of } \\
\text { Squares }\end{array}$ & $d f$ & Mean Square & $F$ & Sig. \\
\hline \multirow[t]{3}{*}{1} & Regression & 11.960 & 6 & 1.993 & 3.853 & $.002^{a}$ \\
\hline & Residual & 36.215 & 70 & .517 & & \\
\hline & Total & 48.175 & 76 & & & \\
\hline
\end{tabular}

a. Predictors: (Constant), MOMKMT, MKDMMEAN, MKCPMEAN, MOMEAN, MKTTMEA MKMTMEAN

b. Dependent Variable: PERFMEAN

c. Selecting only cases for which Telecom or manufacturing = manufacturing

Coartcients, b

\begin{tabular}{|c|c|c|c|c|c|c|}
\hline \multirow{2}{*}{\multicolumn{2}{|c|}{ Model }} & \multicolumn{2}{|c|}{$\begin{array}{c}\text { Unstandardized } \\
\text { Coefficients }\end{array}$} & \multirow{2}{*}{$\begin{array}{c}\begin{array}{c}\text { Standardized } \\
\text { Coefficients }\end{array} \\
\text { Beta }\end{array}$} & \multirow[b]{2}{*}{$t$} & \multirow[b]{2}{*}{ Sig. } \\
\hline & & 8 & Std. Error & & & \\
\hline \multirow[t]{7}{*}{1} & (Constent) & 3.278 & 2.245 & & 1.460 & .149 \\
\hline & MOMEAN & .209 & .577 & .165 & .363 & .718 \\
\hline & MKMTMEAN & -.114 & .680 & -.117 & -.167 & .868 \\
\hline & MKCPMEAN & -.264 & .119 & -.267 & -2.229 & .029 \\
\hline & MKTTMEAN & $-5.98 \mathrm{E}-03$ & .105 & -.008 & -.057 & .955 \\
\hline & MKDMMEAN & .255 & .102 & .290 & 2.489 & .015 \\
\hline & MOMKMT & $1.629 \mathrm{E}-02$ & .170 & .074 & .096 & .924 \\
\hline
\end{tabular}

a. Dependent Variable: PERFMEAN

b. Selecting only cases for which Telecom or manufacturing = manuracturing 
Table 61. Model 3, Regression with competitive intensity multiplicative term for telecommunications companies only

Model Summary

\begin{tabular}{|c|c|c|c|c|}
\hline & $\mathbf{R}$ & & & \\
\hline Model & $\begin{array}{l}\text { Telecom or } \\
\text { manulacturing } \\
=\text { telecom } \\
\text { (Selected) }\end{array}$ & R Square & $\begin{array}{l}\text { Adjusted } \\
R \text { Square }\end{array}$ & $\begin{array}{l}\text { Std. Error of } \\
\text { the Estimate }\end{array}$ \\
\hline 1 & $.614^{a}$ & .377 & .322 & .60822 \\
\hline
\end{tabular}

a. Predictors: (Constant), MOMKCP, MKTTMEAN, MKDMMEAN, MKMTMEAN, MOMEAN, MKCPMEAN

\section{ANOVAb,c}

\begin{tabular}{|ll|r|r|r|r|r|}
\hline Model & $\begin{array}{c}\text { Sum of } \\
\text { Squares }\end{array}$ & df & Mean Square & $F$ & Sig. \\
\hline 1 & Regression & 15.214 & 6 & 2.536 & 6.854 & $.000^{2}$ \\
& Residual & 25.156 & 68 & .370 & & \\
& Total & 40.370 & 74 & & & \\
\hline
\end{tabular}

a. Predictors: (Constant), MOMKCP, MKTTMEAN, MKDMMEAN, MKMTMEAN, MOMEA MKCPMEAN

b. Dependent Variable: PERFMEAN

c. Selecting only cases for which Telecom or manufacturing $=$ telecom

Coefficients,

\begin{tabular}{|c|c|c|c|c|c|c|}
\hline \multirow{2}{*}{\multicolumn{2}{|c|}{ Model }} & \multicolumn{2}{|c|}{$\begin{array}{c}\text { Unstandardized } \\
\text { Coefficients }\end{array}$} & \multirow{2}{*}{$\begin{array}{c}\begin{array}{c}\text { Standardized } \\
\text { Coefficients }\end{array} \\
\text { Beta }\end{array}$} & \multirow[b]{2}{*}{$t$} & \multirow[b]{2}{*}{ Sig. } \\
\hline & & 8 & Std. Error & & & \\
\hline \multirow[t]{7}{*}{1} & (Constant) & 4.672 & 1.696 & & 2.755 & .008 \\
\hline & MONEAN & -.236 & .456 & -.210 & -.518 & .606 \\
\hline & MKMTMEAN & -.184 & .098 & -.201 & -1.872 & .066 \\
\hline & MKCPMEAN & -.735 & .562 & -.727 & -1.308 & .195 \\
\hline & MKTTMEAN & $-4.81 E-02$ & .086 &. .064 & -.559 & .578 \\
\hline & MKDMMEAN & .346 & .070 & .507 & 4.804 & .000 \\
\hline & MOMKCP & .165 & .151 & .719 & 1.097 & .276 \\
\hline
\end{tabular}

a. Dependent Variable: PERFMEAN

b. Selecting only cases for which Telecom or manuiacturing $=$ telecom 
Table 62. Model 3, Regression with competitive intensity multiplicative term for manufacturing companies only

Model Summary

\begin{tabular}{|l|r|r|r|r|}
\hline & & & \\
$\begin{array}{c}\text { Telecom or } \\
\text { manufacturing } \\
= \\
\text { manufacturing } \\
\text { (Selected) }\end{array}$ & R Square & Adjusted & R Square & $\begin{array}{c}\text { Std. Error of } \\
\text { the Estimate }\end{array}$ \\
\hline Model & $.550^{2}$ & .303 & .243 & .69263 \\
\hline 1 & &
\end{tabular}

a. Predictors: (Constant), MOMKCP, MKDMMEAN, MKMTMEAN, MKTTMEAN, MOMEAN, MKCPMEAN

ANOVA,c

\begin{tabular}{|ll|r|r|r|r|r|}
\hline Model & & $\begin{array}{r}\text { Sum of } \\
\text { Squares }\end{array}$ & df & Mean Square & \multicolumn{1}{|c|}{$F$} & Sig. \\
\hline 1 & Regression & 14.594 & 6 & 2.432 & 5.070 & $.000^{2}$ \\
& Residual & 33.582 & 70 & .480 & & \\
& Total & 48.175 & 76 & & & \\
\hline
\end{tabular}

a. Predictors: (Constant), MOMKCP, MKDMMEAN, MKMTMEAN, MKTTMEAN, MOMEA MKCPMEAN

b. Dependent Variable: PERFMEAN

c. Selecting only cases for which Telecom or manufacturing = manufacturing

Coefficients ${ }^{2, b}$

\begin{tabular}{|c|c|c|c|c|c|c|}
\hline \multirow{2}{*}{\multicolumn{2}{|c|}{ Model }} & \multicolumn{2}{|c|}{$\begin{array}{l}\text { Unstandardized } \\
\text { Coefficients }\end{array}$} & \multirow{2}{*}{$\begin{array}{c}\begin{array}{c}\text { Standardized } \\
\text { Coefficients }\end{array} \\
\text { Beta }\end{array}$} & \multirow[b]{2}{*}{$\hat{t}$} & \multirow[b]{2}{*}{ Sig. } \\
\hline & & B & Std. Error & & & \\
\hline \multirow[t]{7}{*}{1} & (Constant) & 8.287 & 2.316 & & 3.578 & .001 \\
\hline & MOMEAN & -1.028 & .567 & -.810 & -1.814 & .074 \\
\hline & MKMTMEAN & $-9.66 E-02$ & .120 & -.099 & -.807 & .422 \\
\hline & MKCPMEAN & -1.789 & .661 & -1.807 & -2.708 & .008 \\
\hline & MKTTMEAN & $-3.86 E-03$ & .094 & -.005 & -.041 & .968 \\
\hline & MKDMMEAN & .194 & .102 & .220 & 1.904 & .061 \\
\hline & MOMKCP & .398 & .170 & 1.951 & 2.345 & .022 \\
\hline
\end{tabular}

a. Depandent Variable: PERFMEAN

b. Selecting only cases for which Telecom or manufacturing = manufacturing 
Table 63. Model 3, Regression with technological turbulence multiplicative term for telecommunications companies only

Model Summary

\begin{tabular}{|l|l|l|l|l|}
\hline \multicolumn{1}{|c|}{$R$} & & & \\
\hline $\begin{array}{c}\text { Telecom or } \\
\text { manufacturing } \\
\text { telecom } \\
\text { (Selected) }\end{array}$ & R Square & $\begin{array}{c}\text { Adjusted } \\
\text { R Square }\end{array}$ & $\begin{array}{c}\text { Sid. Error of } \\
\text { the Estimate }\end{array}$ \\
\hline 1 & $.611^{a}$ & .373 & .318 & .61000 \\
\hline
\end{tabular}

a. Predictors: (Constant), MOMKTT, MKCPMEAN, MKDMMEAN, MKMTMEAN, MOMEAN, MKTTMEAN

ANOVA ${ }^{b, c}$

\begin{tabular}{|c|c|c|c|c|c|c|}
\hline Model & & $\begin{array}{l}\text { Sum of } \\
\text { Squares }\end{array}$ & df & Mean Square & $F$ & Sig. \\
\hline \multirow[t]{3}{*}{1} & Regression & 15.067 & 6 & 2.511 & 6.749 & $.000^{2}$ \\
\hline & Residual & 25.303 & 68 & .372 & & \\
\hline & Total & 40.370 & 74 & & & \\
\hline
\end{tabular}

a. Predictors: (Constant), MOMKTT, MKCPMEAN, MKDMMEAN, MKMTMEAN, MOMEA MKTTMEAN

b. Dependent Variable: PERFMEAN

c. Selecting only cases for which Telecom or manufacturing $=$ telecom

\section{Coeficients ${ }^{\mathrm{a}, \mathrm{b}}$}

\begin{tabular}{|c|c|c|c|c|c|c|}
\hline \multirow{2}{*}{\multicolumn{2}{|c|}{ Model }} & \multicolumn{2}{|c|}{$\begin{array}{c}\text { Unstandardized } \\
\text { Coefficients }\end{array}$} & \multirow{2}{*}{$\begin{array}{c}\begin{array}{c}\text { Standardized } \\
\text { Coeficients }\end{array} \\
\text { Beta }\end{array}$} & \multirow[b]{2}{*}{$t$} & \multirow[b]{2}{*}{ Sig. } \\
\hline & & 8 & Std. Error & & & \\
\hline \multirow[t]{7}{*}{1} & (Constant) & 1.675 & 1.548 & & 1.082 & .283 \\
\hline & MOMEAN & .605 & .412 & .539 & 1.470 & .146 \\
\hline & MKMTMEAN & -.196 & .100 & -.215 & -1.958 & .054 \\
\hline & MKCPNEAN & -.143 & .102 & -.142 & -1.405 & .164 \\
\hline & MKTTMEAN & .283 & .403 & .377 & .702 & .485 \\
\hline & MKDMMEAN & .355 & .071 & .522 & 5.000 & .000 \\
\hline & MOMKTT & $-9.28 E-02$ & .104 & -.587 & -.895 & .374 \\
\hline
\end{tabular}

a. Dependent Variable: PERFMEAN

b. Selecting only cases for which Telecom or manutacturing = telecom 
Table 64. Model 3, Regression with technological turbulence multiplicative term for manufacturing companies only

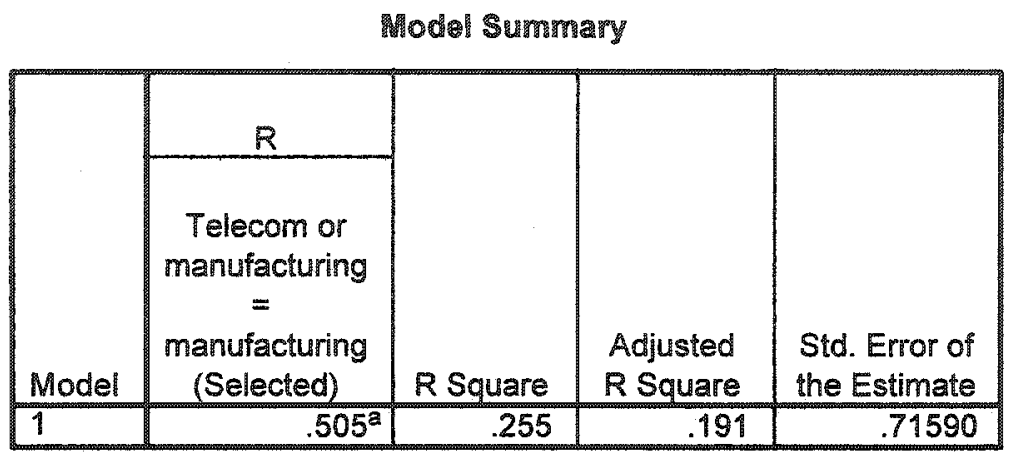

a. Predictors: (Constant), MOMKTT, MKCPMEAN, MKMTMEAN, MKDMMEAN, MOMEAN, MKTTMEAN

ANOVA ${ }^{b, c}$

\begin{tabular}{|c|c|c|c|c|c|c|}
\hline Model & & $\begin{array}{l}\text { Sum of } \\
\text { Squares }\end{array}$ & $d f$ & Mean Square & $F$ & Sig. \\
\hline \multirow[t]{3}{*}{1} & Regression & 12.299 & 6 & 2.050 & 4.000 & $.002^{\mathrm{a}}$ \\
\hline & Residual & 35.876 & 70 & .513 & & \\
\hline & Total & 48.175 & 76 & & & \\
\hline
\end{tabular}

a. Predictors: (Constant), MOMKTT, MKCPMEAN, MKMTMEAN, MKDMMEAN, MOMEA MKTTMEAN

b. Dependent Variable: PERFMEAN

c. Selecting only cases for which Telecom or manufacturing = manufacturing

Coefficients ${ }^{\mathrm{a}, \mathrm{b}}$

\begin{tabular}{|c|c|c|c|c|c|c|}
\hline \multirow{2}{*}{\multicolumn{2}{|c|}{ Model }} & \multicolumn{2}{|c|}{$\begin{array}{c}\text { Unstandardized } \\
\text { Coefficients }\end{array}$} & \multirow{2}{*}{$\begin{array}{c}\begin{array}{c}\text { Standardized } \\
\text { Coefficients }\end{array} \\
\text { Beta }\end{array}$} & \multirow[b]{2}{*}{1} & \multirow[b]{2}{*}{ Sig. } \\
\hline & & 8 & Std. Error & & & \\
\hline \multirow[t]{7}{*}{1} & (Constant) & 4.480 & 1.844 & & 2.430 & .018 \\
\hline & MOMEAN & -.121 & .488 & -.095 & -.248 & .805 \\
\hline & MKMTMEAN & $-1.81 E 02$ & .128 & -.019 & -.141 & .888 \\
\hline & MKCPMEAN & -.287 & .120 & -.290 & -2.400 & .019 \\
\hline & MKTTMEAN & -.423 & .514 & -.574 & -.823 & .413 \\
\hline & MKDMMEAN & .260 & .102 & .296 & 2.549 & .013 \\
\hline & MOMKTT & .109 & .133 & .695 & .819 & .415 \\
\hline
\end{tabular}

a. Dependent Variable: PERFMEAN

b. Selecting only cases for which Telecom or menufacturing = manufacturing 
Table 65. Regression with demand multiplicative term for telecommunications companies only

Moda S Summary

\begin{tabular}{|l|r|r|r|r|}
\hline & $R$ & & \\
\hline $\begin{array}{c}\text { Telecom or } \\
\text { manufacturing } \\
=\text { telecom } \\
\text { (Selected) }\end{array}$ & R Square & R Square & $\begin{array}{c}\text { Sid. Error of } \\
\text { the Estimate }\end{array}$ \\
\hline 1 & $.615^{2}$ & .378 & .323 & .60756 \\
\hline
\end{tabular}

a. Predictors: (Constant), MOMKDM, MKMTMEAN, MKCPMEAN, MOMEAN, MKTTMEAN, MKDMMEAN

ANOVA ${ }^{b, c}$

\begin{tabular}{|c|c|c|c|c|c|c|}
\hline Model & & $\begin{array}{l}\text { Sum of } \\
\text { Squares }\end{array}$ & $d f$ & Mean Square & $\mathrm{F}$ & Sig. \\
\hline \multirow[t]{3}{*}{1} & Regression & 15.269 & 6 & 2.545 & 6.894 & $.000^{a}$ \\
\hline & Residual & 25.101 & 68 & .369 & & \\
\hline & Total & 40.370 & 74 & & & \\
\hline
\end{tabular}

a. Predictors: (Constant), MOMKDM, MKMTMEAN, MKCPMEAN, MOMEAN, MKTTMEA MKDMMEAN

b. Dependent Variable: PERFMEAN

c. Selecting only cases for which Telecom or manufacturing $=$ telecom

Coefficients,

\begin{tabular}{|c|c|c|c|c|c|c|}
\hline \multirow{2}{*}{\multicolumn{2}{|c|}{ Model }} & \multicolumn{2}{|c|}{$\begin{array}{c}\text { Unstandardized } \\
\text { Coefficients }\end{array}$} & \multirow{2}{*}{$\begin{array}{c}\begin{array}{c}\text { Standardized } \\
\text { Coefficients }\end{array} \\
\text { Beta }\end{array}$} & \multirow[b]{2}{*}{$t$} & \multirow[b]{2}{*}{ Sig. } \\
\hline & & $B$ & Std. Error & & & \\
\hline \multirow[t]{7}{*}{1} & (Constant) & 1.502 & 1.385 & & 1.084 & .282 \\
\hline & MOMEAN & .620 & .335 & .552 & 1.847 & .068 \\
\hline & MKMTMEAN & -.173 & .098 & -.189 & -1.762 & .083 \\
\hline & MKCPMEAN & -.127 & .100 & -.126 & -1.270 & .208 \\
\hline & MKTTMEAN & $-6.26 E-02$ & .084 & -.083 & -.746 & .458 \\
\hline & MKDMMEAN & .748 & .350 & 1.098 & 2.135 & .036 \\
\hline & MOMKDM & -.106 & .091 & -.695 & -1.164 & .248 \\
\hline
\end{tabular}

a. Dependent Variable: PERFMEAN

b. Selecting only cases for which Telecom or manuacturing = relecom 
Table 66. Model 3, Regression with demand multiplicative term for manufacturing companies only

moder Summary

\begin{tabular}{|c|c|c|c|c|}
\hline & $R$ & & & \\
\hline Model & $\begin{array}{l}\text { Telecom or } \\
\text { manufacturing } \\
= \\
\text { manufacturing } \\
\text { (Selected) }\end{array}$ & R Square & $\begin{array}{l}\text { Adjusted } \\
\text { R Square }\end{array}$ & $\begin{array}{l}\text { Std. Error of } \\
\text { the Estimate }\end{array}$ \\
\hline 1 & $.537^{a}$ & .288 & .227 & .69993 \\
\hline
\end{tabular}

a. Predictors: (Constant), MOMKDM, MKMTMEAN, MKCPMEAN, MOMEAN, MKTTMEAN, MKDMMEAN

ANOVA $^{b, c}$

\begin{tabular}{|c|c|c|c|c|c|c|}
\hline Model & & $\begin{array}{l}\text { Sum of } \\
\text { Squares }\end{array}$ & $d f$ & Mean Square & $F$ & Sig. \\
\hline \multirow[t]{3}{*}{1} & Regression & 13.882 & 6 & 2.314 & 4.723 & $.000^{a}$ \\
\hline & Residual & 34.293 & 70 & .490 & & \\
\hline & Total & 48.175 & 76 & & & \\
\hline
\end{tabular}

a. Predictors: (Constant), MOMKDM, MKMTMEAN, MKCPMEAN, MOMEAN, MKTTMEAI MKDMMEAN

b. Dependent Variable: PERFMEAN

c. Selecting only cases for which Telecom or manufacturing = manufacturing

Coefficients, b

\begin{tabular}{|c|c|c|c|c|c|c|}
\hline \multirow{2}{*}{\multicolumn{2}{|c|}{ Model }} & \multicolumn{2}{|c|}{$\begin{array}{c}\text { Unstandardized } \\
\text { Coefficients }\end{array}$} & \multirow{2}{*}{$\begin{array}{c}\begin{array}{c}\text { Standardized } \\
\text { Coefficients }\end{array} \\
\text { Beta }\end{array}$} & \multirow[b]{2}{*}{ t } & \multirow[b]{2}{*}{ Sig. } \\
\hline & & $B$ & Std. Error & & & \\
\hline \multirow[t]{7}{*}{1} & (Constant) & .213 & 1.584 & & .135 & .893 \\
\hline & MOMEAN & 1.014 & .403 & .799 & 2.519 & .044 \\
\hline & MKMTMEAN & $-9.67 E-02$ & .122 & -.099 & -.795 & .429 \\
\hline & MKCPMEAN & .190 & .119 & -.192 & -1.598 & .115 \\
\hline & MKTTMEAN & $-2.80 E-02$ & .096 & -.038 & -.292 & .771 \\
\hline & MKDMMEAN & 1.292 & .533 & 1.470 & 2.426 & .018 \\
\hline & MOMKDM & -.272 & .137 & -1.410 & -1.983 & .051 \\
\hline
\end{tabular}

a. Dependent Variable: PERFMEAN

b. Selecting only cases for which Telecom or manufacturing = manufacturing 